University of Louisville

ThinkIR: The University of Louisville's Institutional Repository

8-2012

\title{
An exploration of African folktales among the Gullah community of the South Carolina Sea Islands : history, culture, and identity.
}

Tytianna Nikia Maria Wells Smith 1987-

University of Louisville

Follow this and additional works at: https://ir.library.louisville.edu/etd

\section{Recommended Citation}

Smith, Tytianna Nikia Maria Wells 1987-, "An exploration of African folktales among the Gullah community of the South Carolina Sea Islands : history, culture, and identity." (2012). Electronic Theses and Dissertations. Paper 1352.

https://doi.org/10.18297/etd/1352

This Master's Thesis is brought to you for free and open access by ThinkIR: The University of Louisville's Institutional Repository. It has been accepted for inclusion in Electronic Theses and Dissertations by an authorized administrator of ThinkIR: The University of Louisville's Institutional Repository. This title appears here courtesy of the author, who has retained all other copyrights. For more information, please contact thinkir@louisville.edu. 


\title{
AN EXPLORATION OF AFRICAN FOLKTALES \\ AMONG THE GULLAH COMMUNITY \\ OF THE SOUTH CAROLINA SEA ISLANDS: \\ HISTORY, CULTURE, AND IDENTITY
}

\section{By}

\section{Tytianna Nikia Maria Wells Smith}

B.A., English, 2009

B.A., Pan-African Studies, 2009

\author{
A Thesis \\ Submitted to the Faculty of the \\ College of Arts and Sciences of the University of Louisville \\ In Partial Fulfillment of the Requirements \\ For the Degree of
}

\author{
Master of Arts \\ Department of Pan-African Studies \\ University of Louisville \\ Louisville, Kentucky
}

August 2012 
Copyright 2012 by Tytianna Nikia Maria Wells Smith

All rights reserved 


\section{AN EXPLORATION OF AFRICAN FOLKTALES AMONG THE GULLAH COMMUNITY OF THE SOUTH CAROLINA SEA ISLANDS: HISTORY, CULTURE, AND IDENTITY}

\section{By}

Tytianna Nikia Maria Wells Smith

B.A., English, 2009

B.A., Pan-African Studies, 2009

A Thesis Approved on

August 7, 2012

by the following Thesis Committee:

Yvonne V. Jones

Thesis Director

Karen Chandler

Latrica Best 


\section{DEDICATION}

This thesis is in memory of:

My daughter, Nadia Michelle (May 19, 2005)

My father, Tyrone Clifford Wells (October 12, 1954- July 7, 2010)

This thesis is dedicated to:

My compassionate husband, Jerald Henry Smith

My resilient mother, Le'Donna Maria Smith

\& seven 


\section{ACKNOWLEDGEMENTS}

In the production of this thesis, I would like to thank my thesis committee members. Dr. Latrica Best, your socio-cultural perspective helped guide my research. Thank you for acknowledging my interest in the Black family. Dr. Karen Chandler, your unrelenting encouragement has helped me to accomplish many goals as an aspiring author and teacher. Thank you for supporting me throughout my undergraduate and graduate career. To my thesis committee chair, Dr. Yvonne Jones, your high-expectations helped to enrich this research. Thank you for the challenge.

I would also like to thank Emily Freund at the University of Louisville Writing Center for reading and commenting on my entire thesis; Dr. Catherine Fosl, Director of the Anne Braden Institute for Social Justice Research who was an empowering mentor; and my family in Michigan and Kentucky whose stories are my own. 


\author{
ABSTRACT \\ AN EXPLORATION OF AFRICAN FOLKTALES \\ AMONG THE GULLAH COMMUNITY \\ OF THE SOUTH CAROLINA SEA ISLANDS: \\ HISTORY, CULTURE, AND IDENTITY \\ Tytianna Nikia Maria Wells Smith
}

August 7, 2012

This thesis is an exploration of Black cultural space and its influence on the retention, adaptation, and transmission of African folktales during and after the antebellum era. During slavery, the survival of kinship and family helped to create an environment that existed through which African folktales were used to educate and socialize children on South Carolina Sea Islands plantations. This research conducted a literary and cultural analysis of the historical and current function of ten folktales that impart moral lessons and cultural values that encourage children in Gullah communities to appreciate their African heritage and challenge the world in which they live in the United States of America. 


\section{TABLE OF CONTENTS}

PAGE

DEDICATION .......................................................

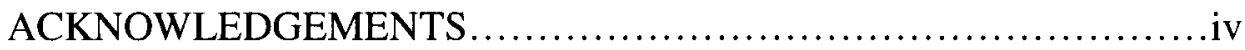

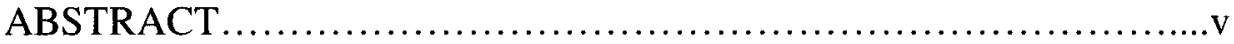

CHAPTER 1 INTRODUCTION .........................................

CHAPTER II: LITERATURE REVIEW .............................12

CHAPTER III: METHODOLOGY ...................................30

CHAPTER IV: THE HISTORICAL SETTING ......................56

CHAPTER V: THE FAMILY AND CHILD SOCIALIZATION...........82

CHAPTER VI: LITERARY AND CULTURAL ANALYSIS..............105

CHAPTER VII: SUMMARY AND CONCLUSION..................146

REFERENCES................................................... 164

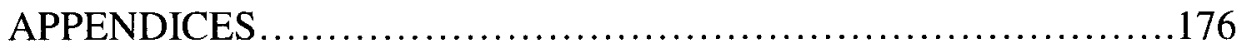

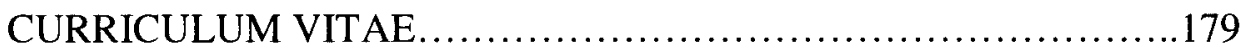




\section{CHAPTER I}

\section{INTRODUCTION}

Stories are the way we make sense of our lives: by telling them we tell ourselves who we are, why we're here, how we come to be what we are, what we value most, and how we see the world. ${ }^{I}$

Purpose of Study

This thesis explores African folktales as encountered among the Gullah community of the South Carolina Sea Islands to interpret their idioms, meanings, and functions for the people who created them. This research observes the historical and current function of African folktales that impart moral lessons and cultural values to educate and socialize Gullah children. African folktales have long encouraged Gullah children to foster resiliency and positive racial identity development. This chapter defines folklore and folktales, the adaptation of African folktales, and defines animal and human tales to support this research which mainly focuses on a literary and cultural analysis.

\section{Defining Folklore and Folktales}

This research relies on the instructional function of folklore with an emphasis on folktales. Coined in 1846 by an Englishman, William John Thoms, folklore is, "The loving study of manners, customs, observances, superstitions, ballads, proverbs, etc. of the olden time." Today, folklore broadly encompasses folktales, dances, fables, customs, 
parables, toasts, proverbs, spirituals, trickster tales, ballads, aphorisms, and heroine tales

to name a few. These elements of culture make folklore the oldest form of education. ${ }^{2}$

Martha Sims and Martine Stephens write:

The term folklore refers to the knowledge we have about our world and ourselves that we don't learn in school or textbooks-we learn folklore from each other. It's the informally learned, unofficial knowledge we share without peers, families and other groups we belong to." Furthermore, "Folklore is informally learned, unofficial knowledge about the world, ourselves, our communities, our beliefs, our cultures and our traditions, that is expressed creatively through words, music, customs, actions, behaviors and materials. It is also the interactive, dynamic process of creating, communicating, and performing as we share that knowledge with other people. ${ }^{3}$

According to William Bascom, folklore has four functions: "educating; escaping accepted limitations of our culture; maintaining cultural identity; and validating existing claims: "folklore is an important mechanism in maintaining the stability of culture."” Folklore is a collection of cultural traditions that functions to provide a traditional form of schooling within a given society that transmits knowledge and wisdom from one generation to the next. Alan Dundes explains that folklore educates children, encourages kinship and family unity, provides a code of conduct, and creates alternative ways to deal with daily issues. ${ }^{4}$ African folktales metaphorically depict the trauma and triumph of the Black experience.

\section{The Adaptation of African Folktales}

African folktales were transplanted from pre-colonial West Africa to the Americas, and, since slavery, the tales have undergone transmutation and adaptation from animal to human tales. This adaptation signifies a figurative and literal depiction of life 
on the African continent with life on the plantation. ${ }^{5}$ Langton Hughes and Arna Bontemps explain the African origin of folktales in the United States:

Negro folklore, like almost any other kind can be traced in its origins to a dim past when it drew on a common cultural heritage, which most of the folk of the world appear to have. In any case, the telling of tales is a time honored custom in Africa... the slaves brought with them to the New World their ancient habit of story telling as pastime, together with a rich bestiary. ${ }^{6}$

Prior to colonial Africa, folklore served as one of the most important daily practices on the continent. In West Africa, Anansi the Spider and Cunnie Rabbit were among the animal tales told. Other animal tales detailed characters such as the hyena, fly, spider, crocodile, and lion. However, these animal characters soon changed after the transAtlantic slave trade transplanted African slaves from the continent to North America. They brought with them, African cultural traditions such as folktales that adapted to life on the plantation. Although the typography of African-derived animal tales began to reshape on the plantation, the function of these tales remained the same. These tales detailed the quirky trickster traits of animals indigenous to Africa, but mostly indigenous to the Sea Islands. These animals included the rabbit, alligator, squirrel, and eagle. ${ }^{7}$

\section{Defining Animal and Human Tales}

Animal tales served as a creative technique to preserve African heritage on the plantation. The slaves used animal tales not only to disguise their connection to animals and nature, but to disguise their hidden emotions towards White persons. As a result, these ambiguous tales were nonthreatening to slaveholders. Animal tales include characters such as Brer Rabbit, and human tales include characters such as John. ${ }^{8}$ 
In African folktales documented on the Sea Islands, the animal characters include Brer Rabbit, Brer Alligator, and Brer Possum, and a host of others. Although these animal characters are different in species, versions of the term "Brother" (Brer, B'r, Bra, Bru, Buh, Bruh, and Budder) that is an African feature indicates a level of respect and endearment even between two enemies who are constantly at odds with one another. ${ }^{9}$

John W. Blassingame writes:

Animals in the tales refer to each other as 'brother' in the same manner that slaveholders referred to their chattel as 'family.' On one side, they are indeed 'brothers' and 'family,' for they belong to the same species. On the other hand, certain characteristics, such as race or class, circumvent true kinship. These lessons were not lost on the young. ${ }^{10}$

For example, Brer Rabbit outwits or outsmarts physically larger animals such as Brer Lion. Animal characters such as Brer Rabbit are considered heroes because they almost always outwit the physically larger but mentally weaker animals. The animal trickster figure that overcomes obstacles is celebrated as an example of heroism needed to survive on the plantation. John W. Roberts writes, "Most could readily equate the character and actions of the animal trickster with those of Africans on the continent, but could not, however, so easily accept them as a completely accurate reflection of black identity or behavior, actual or potential, in America."11

Animal tales adapted to life on the plantation and transformed from animal to human. Brer Rabbit was replaced with a slave man named John, Jack or Jim. Brer Alligator was replaced with a slaveholder named Old Master, Massa or Whitey. Human tales that culturally transformed to reflect a change in time and history were a direct and explicit account of life as a slave on the plantation. Due to its realistic characteristics, 
human tales were not spoken in close proximity to slaveholders because the message was not ambiguous as opposed to those in animal tales. These guarded tales helped slaves celebrate success over the slaveholder, secretly. The candor of human tales was a major distinction between the animal and human tale. The slaves knew John, a man whose heroic attributes were imitated within the slave community. For example, John is described as either quick-thinking or slow thinking which allows him to get the best of Old Master. This is especially evident when John tolerates Old Master while concealing his true emotions and rebellious conduct through trickery to both accept and resist paternalism on the plantation. ${ }^{12}$ Blassingame writes:

Not only did these cultural forms give the slave an area of life independent of his master's control, they also were important psychological devices for repressing anger and projecting aggressions in ways that contributed to mental health, involved little physical threat, and provided some form of recreation. By objectifying the conditions of his life in the folk tales, the slave was in a better position to cope with them. ${ }^{13}$

John and Old Master tales highlight the realistic relationship and conflict between the slave and the slaveholder. In human tales, John does not succeed as often as Brer Rabbit. The human tales portray a considerable amount of conquering by the antagonist compared to the animal tales causing "Old Master" to win rather than John. This implies that human tales revealed a more accurate depiction of life on the plantation. However, in human tales specific to plantations such as the All Saints Parish plantations, John never fails. This could demonstrate that John or the slave was able to succeed over the oppressor more than usual on the All Saints Parish plantations in comparison to neighboring plantations which could be in response to living conditions specific to the plantation. Nevertheless, whether or not John overcame his situation against Old Master, 
it was a reminder to slaves that conflict with their masters was only temporary. ${ }^{14}$

Essentially, these tales were well-designed to mirror the struggles and victories that impacted the life of the slave. Although less is known about human trickster tales, Black children are connected to the content of the animal and human tales. These tales were functional in educating and socializing children about the world and social conditions in which the slaves lived. Steve Sanfield believes that children whose lives are typically controlled by parents, teachers, and older children instantly relate to trickster characters because both experience bouts of oppression. ${ }^{15}$ According to Joyner:

He [John] expressed the value and attitudes of his fellow slaves directly. In his inevitable victories over the more powerful master (and thus over the slave system), John provided the slave community with perspective by incongruity. Buh Rabbit tales might be narrated to the master's family as well as to one's fellow slaves, but John tales were for telling only among the slaves. ${ }^{16}$

Although John is not Brer Rabbit's equal, both animal and human characters symbolize the slave-slaveholder relationship on the plantation and an investment in gaining freedom. No matter the differences or similarities between animal and human tales, these tales are both authentic and exaggerated versions of the slaves' lives. ${ }^{17}$

\section{Significance of Study}

This research justifies the historical and current use of African folktales that impart moral lessons and cultural values to educate and socialize Gullah children. It focuses on the significance of African folktales as retention in the Gullah community. For examples, during slavery, folktales served as an informal educational tool when formal education was prohibited. African folktales are fables that teach members of the Gullah 
community about their African history, culture, and identity. Furthermore, the transmissions of these fable tales help preserve memories, communicate moral lessons and cultural values, and encourage the appreciation of African heritage. Roberts writes:

Opportunistically, however, as Africans pooled their individual memories and contested their abilities as raconteurs in the telling of animal trickster tales in the course of evening entertainments, they soon realized that the basic behaviors of their African animal trickster and the situations in which their actions unfolded objectified types of situations with which they had not only been all too familiar in Africa but also continued to experience in America. ${ }^{18}$

The goal of African folktales has always been to transfer tales from one generation to the next to not only keep memories alive, but, most importantly, to espouse a rational message about life on the plantation. These tales teach valuable lessons about African-centered morals, values, customs and traditions with the purpose of preserving the African way of life.

Research Outline

This research consists of seven chapters. Each chapter encompasses an exploration of the development of Black cultural space and its impact on the historical and contemporary function of African folktales in the slave and contemporary Gullah community. Chapter 2 provides a literature review that explains the primary and secondary sources used to conduct this research. These sources are historical, sociocultural, linguistic, and folkloric. The content of these sources is recognized as aiding this research.

Chapter 3 focuses on the methods used to conduct this research. This chapter 
addresses two questions that propel the research, and identifies the socio-cultural historical approach used to conduct the literary and cultural analysis of African folktales. The methods used to conduct this study are examined within the subheadings: etymology and nomenclature, overview, sources, research design, research demonstration, cultural change and African folktales, facts and figures, and statement of problem.

Chapter 4 provides a historical context with a focus on three periods of the transAtlantic slave trade. This research considers the factors that made it possible for slaves to retain and transform their African cultural traditions such as folktales. These factors include: the geography, the influx of slaves from specific regions of West Africa, White absenteeism, and the role of the task system. These factors helped develop Black cultural space that created Gullah-speaking communities on South Carolina Sea Islands plantations.

Chapter 5 investigates the conditions of slavery that facilitated the emergence of Black cultural space on South Carolina Sea Islands plantations. This chapter also observes the parameters of kinship and family on the plantation and in the current Gullah community to explain the cultural contexts in which African derived folktales have functioned to educate and socialize children.

Chapter 6 is a literary and cultural analysis of African folktales. Ten African folktales are summarized, analyzed, and interpreted as functional in imparting moral lessons and cultural values. These cautionary, escape, humorous, and/or trickster animal and human tales teach lessons pertaining to: parent $\&$ child responsibilities, racial identity \& White privilege, human interactions, and building character traits such as courage, bravery, and resiliency. These tales prepare the Black child to rise above adversity while 
developing a positive racial identity.

Chapter 7 is a summation of the previous chapters. This chapter returns to the presence of Black cultural space and its influence on the retention of African folktales and their transmission of lessons throughout Gullah communities from slavery to the present-day. This chapter details the Great Migration that followed Reconstruction to highlight five Sea Islands and its residents, organizations that serve as a political response against the threatened encroachment of Gullah persons, Melville J. Herskovits's anthropological research on cultural change, and research findings that verify the adaptation of African folktales in the Gullah community on the South Carolina Sea Islands. 


\section{CHAPTER I}

${ }^{1}$ Gary Colombo, Bonnie Lisle, and Sandra Mano, Framework: Culture, storytelling and college writing (Boston, MA: Bedford Books, 2007). 5.

${ }^{2}$ Bruce Jackson, American Folklore Society, Judith McCulloh, and Marta Weigle. Folklore/Folklife. ed. Bruce Jackson and American Folklore Society (Bloomington, IN: Indiana University, 1984). 5; Hazel A. Ervin, The Handbook of African American Literature (Gainesville, FL: University Press of Florida, 2004). 63; Craig Roney, "Telling Stories: A Key to Reading and Writing," in Once Upon a Folktale: Capturing the Folklore Process With Children, ed. Gloria T. Blatt (New York, NY: Teachers College Press, 1993). 9. ${ }^{3}$ Martha Sims, and Martine Stephens. Living Folklore: An Introduction to the Study of People and Their Traditions (Logan, UT: Utah State University Press, 2005). 4-8.

${ }^{4}$ William R. Bascom, "Four Functions of Folklore," in The Study of Folklore, ed. Alan Dundes (Englewood Cliffs, NJ: Prentice-Hall, Inc., 1965). 279; William R. Bascom, "Folklore and Anthropology," in The Study of Folklore, ed. Alan Dundes (Englewood Cliffs, NJ: Prentice-Hall, Inc., 1965). 33; Alan Dundes, "The Functions of Folklore," in The Study of Folklore, ed. Alan Dundes (Englewood Cliffs, NJ: Prentice-Hall, Inc., 1965). 277; Sims and Stephens, Living Folklore, 152; William S. Pollitzer, The Gullah People and Their African Heritage (Athens, GA: University of Georgia Press, 1999). 159; Dundes, "The Functions of Folklore," 278.

${ }^{5}$ Charles Joyner, Shared Traditions: Southern History and Folk Culture (Urbana, IL: University of Illinois Press, 1999). 37

${ }^{6}$ Langston Hughes and Arna Bontemps, ed. The Book of Negro Folklore (New York, NY: Dodd and Meade, 1958), viii.

${ }^{7}$ Pollitzer, The Gullah People and Their African Heritage, 158; Sims and Stephens, Living Folklore, 3; John W. Blassingame, The Slave Community: Plantation Life in the Antebellum South (New York, NY: Oxford University Press, Inc., 1972). 23; John W. Roberts, From Trickster to Badman: The Black Folk Hero in Slavery and Freedom (Philadelphia, PA: University of Pennsylvania Press, 1989). 26; Joseph F. Holloway, Africanisms in American Culture (Bloomington, IN: Indiana University Press, 1991). 16; Naomi Barnett and Gloria T. Blatt, "Anansi, A Hero For All Seasons," in Once Upon a Folktale: Capturing the Folklore Process With Children, ed. Gloria T. Blatt New York, NY: Teachers College Press, 1993). 157; Priscilla Jaquith,"Folktale Decisions" in Sitting at the Feet of the Past: Retelling the North American Folktales for Children, ed. Gary D. Schmidt and Donald R. Hettinga Westport, CT: Greenwood Press, 1992). 78.

${ }^{8}$ Lawrence W. Levine, Black Culture and Black Consciousness: Afro-American Folk Thought from Slavery to Freedom (New York, NY: Oxford University Press, 1977). 133.

${ }^{9}$ Roberts, From Trickster to Badman, 28.

${ }^{10}$ Blassingame, The Slave Community, 127-128.

"Levine, Black Culture and Black Consciousness, 121; Harold Courlander, Afro American Folklore: The Oral Literature, Traditions, Recollections, Legends, tales, Songs, Religious Beliefs, Customs, Sayings and Humor of Peoples of African Descent in the Americas (New York, NY: Marlowe \& Company, 1976). 467; Levine, Black Culture and Black Consciousness, 118; Ibid., 112; J. Mason Brewer, American Negro Folklore (Chicago, IL: Quadrangle, 1968). 3-4; Julius Lester, On Writing for Children \& Other People (New York: NY: Dial Books, 2004).117; Ibid., 117; Sterling Brown, The Negro in American Fiction (Washington, D.C.: The Associates in Negro Folk Education, 1937). 54; Wilma King, Stolen Childhood: Slave Youth in Nineteenth-Century America (Bloomington, IN: Indiana University Press, 1995). 177; Blassingame, The Slave Community, 61; Charles Joyner, Down by the Riverside: A South Carolina Slave Community (Urbana, IL: University of Illinois Press, 1984). 172; Roberts, From Trickster to Badman, 19. ${ }_{12}$ Joyner, Shared Traditions, 37; Roberts, From Trickster to Badman, 61; Joyner, Down by the Riverside, 183-189; Courlander, Afro American Folklore, 419-420; Blassingame, The Slave Community, 129. ${ }^{13}$ Ibid., 129.

${ }^{14}$ King, Stolen Childhood, 72; Joyner, Down by the Riverside, 185; Levine, Black Culture and Black Consciousness, 89-104.

${ }^{15}$ Brown, The Negro in American Fiction, 54; Steve Sanfield, "Across Cultures: Stories That Say L'Chaim," in Sitting at the Feet of the Past: Retelling the North American Folktales for Children ed. Gary 
D. Schmidt and Donald R. Hettinga (Westport, CT: Greenwood Press, 1992). 69-76.

${ }^{16}$ Joyner, Down by the Riverside, 189.

${ }^{17}$ King, Stolen Childhood, 72; Joyner, Down by the Riverside, 189; Courlander, Afro American Folklore, 257; Richard M. Dorson, American Negro Folktales (Bloomington, IN: Indiana University Press, 1956). 124; Joyner, Down by the Riverside, 178.

${ }^{18}$ Roberts, From Trickster to Badman, 33. 


\section{CHAPTER II}

\section{LITERATURE REVIEW}

This chapter is an explanation of the primary and secondary sources consulted for this research. This thesis utilizes historical, socio-cultural, linguistic, and folkloric sources observed within a thematic overview to discuss the development of Black cultural space and its influence on the function of African folktales in the Gullah community.

\section{Historical Sources}

Throughout this research, the following historical sources are used to observe slavery on the South Carolina Sea Islands: a diary, letterbook, journal, and oral history containing interviews. Primary sources include Charlotte Forten's The Journals of Charlotte Forten Grimke, Eliza Lucas's The Letterbook of Eliza Lucas Pinckney, 1739 1762 (1738), Frances A. Kemble's Journal of a Residence on a Georgian Plantation in 1838-1839 (1863), John W. Blassingame's Slave Testimony: Two Centuries of Letters, Speeches, Interviews, and Autobiographies (1977), Guy and Candie Carawan's Ain't You Got a Right to the Tree of Life: The People of Johns Island, South Carolina, their Faces, their Words, and their Songs (1989), and Patricia Jones-Jackson's When Roots Diel Endangered Traditions on the Sea Islands (1987). Forten's Journals is a first person account of conditions that she observed and experienced on the South Carolina Sea 
Islands. It focuses on the role of a northern Black schoolteacher who teaches at a plantation school on St. Helena Island. This text is noted in chapter 5 to provide a daily description of literacy in the contraband community before and after a formal school was established as an experiment during the Civil War. Lucas's Letterbook is a type of diary that offers a historical description of her experimentation with indigo. In chapter 4 , this text is considered as a personal account of her life on the indigo-producing Pinckney Plains plantation. Kemble's Journal is also a type of diary. Kemble's account of her personal experience represents the perspective of the wife of a slaveholder on the plantation. This account details the lifestyle of absentee owners on the Sea Islands that is explored in chapter 4. Lucas and Kemble's texts bring out the experience of two White women who were involved to some degree with the business of slavery. Their perspective was in juxtaposition to the slaves' life. These sources explain the internal system of slavery not from the slaveholder's perspective, but from that of the mistress who is sympathetic to slaves. Blassingame's Slave Testimony addresses a series of oral histories that result from scholars' interviews with former slaves. The slave narratives describe the task system regimen and the presence of physical punishment on Sea Islands plantations that are reflected in chapter 4. Carawan and Carawan's Ain't You Got a Right to the Tree of Life is also consulted as a collection of oral history that reveals the voices of interviewed descendants of African slaves on the South Carolina Sea Islands. These interviews help to explain the transmission of African folktales from generation to generation as examined in chapter 5. Jones-Jackson's When Roots Die/ Endangered Traditions on the Sea Islands is a collection of interviews conducted with the descendants of slaves who have managed to preserve and celebrate their African heritage. These 
interviews that emphasize the perspectives of older Black persons on the South Carolina Sea Islands who, since slavery, have continued to appreciate their African heritage by practicing cultural traditions such as folktales to educate and socialize children are highlighted in chapter 4 .

This research also consults comprehensive historical sources that present a cultural description of the slaves on South Carolina Sea Islands plantations. These sources include: Willie Lee Rose's Rehearsal for Reconstruction: the Port Royal Experiment (1964), Eugene Genovese's Roll Jordan Roll: The World the Slaves Made (1972), Peter Wood's Black Majority: Negroes in Colonial South Carolina from 1670 through the Stono Rebellion (1974), Herbert Gutman's The Black Family in Slavery and Freedom, 1750-1925 (1976), Ira Berlin's “Time, Space, and the Evolution of AfroAmerican Society on British Mainland North America" (1980), Charles Joyner's Down by the Riverside: A South Carolina Slave Community (1984), Margaret Washington Creel's "A Peculiar People" Slave Religion and Community-Culture among the Gullahs (1988), Joseph F. Holloway's Africanisms in American Culture (1991), Jeffrey Bolster's Black Jacks: African American Seamen in the Age of Sail (1997), and Isabel Wilkerson's The Warmth of Other Suns: The Epic Story of America's Great Migration (2010). Rose's Rehearsal for Reconstruction is an important book dealing with The Port Royal Experiment on St. Helena Island which encouraged northern missionaries and teachers to help educate and train newly emancipated persons in a commitment to freedom and racial equality on the South Carolina Sea Islands. Chapter 5 considers this text not only to examine the experiment, but to illustrate accelerated Black land loss for newly emancipated persons and its impact on childhood socialization in the Black family. 
Genovese's Roll Jordan Roll depicts slave life with a focus on paternalism and the ways slaves resisted on the plantation that is emphasized in chapter 4 . This text also yields the lessons slave parents taught children on the plantation as discussed in chapter 5 . However, the lessons imparted from the tales' content are further explored in chapter 6 which presents a literary and cultural analysis of ten African folktales. Wood's Black Majority focuses on the colonial and Black history of African slaves in South Carolina. This text describes slave labor and resistance on Sea Islands plantations. Wood's text provides an example of the Stono Rebellion of 1739 that is highlighted in chapter 4. Gutman's The Black Family in Slavery and Freedom, 1750-1925 observes the family system within the slave community. This text is used in chapter 4 to depict Good Hope as one of the prominent, cotton-producing plantations on the South Carolina Sea Islands. In chapter 5 , this text is also consulted to detail kinship ties in the slave community. Gutman uses data from plantation birth register lists, county census schedules, and Negro Cohabitation Certificates to compare Good Hope to other plantations throughout the antebellum South, and to explain that the Black family remained stable and resilient during and after slavery. Berlin's "Time, Space, and the Evolution of Afro-American Society on British Mainland North America" explains the incentives of the task system as a method of slave labor on the plantation. In chapter 4 , this text describes the conditions under which slaves were permitted leisure time once daily tasks were completed. Joyner's Down by the Riverside illustrates slave life specifically on rice-producing plantations in South Carolina. This text addresses slave life and the use of African folktales on the plantation as reflected in several chapters of this research. Joyner's text discusses the task system as a method of slave labor used to cultivate rice on South 
Carolina Sea Islands plantations which is examined in chapters 4 and 5. This text briefly describes in chapters 1 and 7, the adaptation and preservation of African folktales that helped create Black cultural space on the plantations. Margaret Washington Creel's " $A$ Peculiar People" argues that the majority of the slaves from West Africa have had the most influence on the cultural autonomy of slave communities on the Sea Islands. This text provides three eras that help structure the historical framework of this research in chapter 4. Holloway's Africanisms in American Culture claims that the majority of the slaves from Central Africa (i.e. Angola) have had the most influence on the Gullah communities on the South Carolina Sea Islands. Its recognition of the three eras present in Margaret Washington Creel's text makes it an important text in the chronological structure of chapter 4. Bolster's Black Jacks explores the incentives of maritime work or Black seafaring as a method of slave labor away from the plantation for male slaves. Its incentives, as identified in chapter 4 were the freedom of waterway transportation that helped provide slaves access to surrounding plantations on the Sea Islands. Wilkerson's The Warmth of Other Suns is the most thorough scholarly investigation of the Great Migration or Great Black Migration. This book provides census records to refer to the migration patterns of southern African Americans to northern states for better civil opportunities. In chapter 7, this book is used to explain how after the Civil War called Reconstruction, the presence of Black residents were threatened on the Sea Islands. This book supports the discussion of the historical and contemporary encroachment of African Americans who identify as Gullah persons. Since Reconstruction, the in-migration of White persons interested in economically benefitting from the tourism industry helps contribute to Black land loss and the out-migration of African Americans who identify as 
Gullah persons on the South Carolina Sea Islands.

These historical sources are used jointly because they focus on the taking of Africans with the trans-Atlantic slave trade, the regional interest in rice-cultivating Africans, production of slave labor, resident and absentee owners, maritime economy, and the Great Migration. These factors contributed to the preservation of African heritage and the development of Black Americans known as Gullah on the South Carolina Sea Islands. Jointly, these sources present a historical account of slaves on the plantation by focusing on particular plantations, the cultivation of crops, production, and leisure. However, these sources fail to explore the development of Black cultural space and its influence on African folktales in the Gullah community. As a result, Black cultural space is a concept in which this thesis contributes.

\section{Socio-Cultural Sources}

The socio-cultural sources used in this research present data on the historical and current Black family in America with a concentration on African cultural traditions such as folktales in the Gullah community on the South Carolina Sea Islands. These sources include: Melville J. Herskovits's The Myth of the Negro Past (1958), Andrew Billingsley's Black Families in White America, Climbing Jacob's Ladder: The enduring legacy of African American families (1992), Harriette Pipes McAdoo's Black Children: Social, Educational, and Parental Environments (2002), K. Sue Jewell's Survival of the African American Family: The Institutional Impact of U.S. Social Policy (2003), and Harriette Pipes McAdoo's Black Families (2007). Herskovits's The Myth is referenced thoroughly for the purpose of each chapter in this research because it examines the 
presence of Africanisms or African survivals in the Black community to debunk the myth that persons of African descent are pathological and devoid of a distinct African heritage. Moreover, The Myth was the first book to assert that Africanisms such as African folktales were "cultural luggage brought by Africans to this hemisphere." According to Margaret Wade-Lewis, "The Myth is the first study to demonstrate convincingly that many cultural patterns from Africa have been retained and reinterpreted among African people in North America, South America, and the Caribbean." The Myth and Herskovits's theory of cultural change helped propel research on persons of African descent that focused on African survivals such as folklore in Black communities including the Gullah community on the South Carolina Sea Islands. Recent studies of the African Diaspora also emphasize African survivals.

Furthermore, David Evans also presents research on the survival of Africanderived elements including folk musical instruments in Black communities in the United States. His observation supports Herskovits's process of acculturation when he writes, "Retention, syncretism, and reinterpretation can be viewed as sequential stages in a process of acculturation, although they cannot be assigned to specific historical periods because of ongoing cultural contact with African and other outside areas."” Evans also incorporates an additional term to the process of acculturation: revival. The term revival describes the processes in which Herskovits indirectly promoted without recognized realizing it during his research. ${ }^{4}$ The Myth presents an authentic portrait of the Black experience in America thus challenging racial disparity.

\section{Billingsley's Black Families in White America, Climbing Jacob's Ladder} provides a positive view on Black families in America. This book focuses on the 
strengths of Black families by stressing that Black persons have managed to survive despite racism and oppression. Chapter 5 considers the five ways in which the Black family socializes children to appreciate their African heritage as examined in this book. McAdoo's Black Children references a number of researchers and their findings on childhood development in America with a particular focus on Black children. It defines concepts such as racial identity development to explain the social conditions that have affected Black Americans. In chapter 5, this book is used to exemplify that the interactions between Black children and others construct social knowledge or the understanding of one's social environment. Jewell's Survival of the African American Family observes how racial inequality complicates the lives of Black families in America as described in chapter 5. McAdoo's Black Families is a collection of several articles written by different authors focusing on the Black family. For example, Wade W. Noble's "African American Family Life: An Instrument of Culture" is an article that presents a contemporary analysis of the Black family and Black cultural patterns in America. In chapter 5, this text is observed in the discussion of the parents' role in helping children to successfully develop into adulthood.

Additionally, the following socio-cultural texts predominately focus on the African cultural elements of Black communities in America such as the Gullah community: Lawrence W. Levine's Black Culture and Black Consciousness: AfroAmerican Folk Thought from Slavery to Freedom (1977), Joseph F. Holloway's Africanisms in American Culture (1991), Patricia Guthrie's Catching Sense: African American Communities on a South Carolina Sea Island (1996), William S. Pollitzer's The Gullah People and Their African Heritage (1999), and Wilbur Cross's Gullah 
Culture in America (2008). Levine's Black Culture and Black Consciousness is a comprehensive study of African cultural traditions in Black communities in the United States that is referenced throughout this research, but more considerably in chapter 6 . This book is consulted because it presents a complex analysis of African cultural traditions including African folktales which he described as a reflection of the Black experience. Holloway's Africanisms in American Culture identified the presence of Africanisms or African survivals such as folktales that were preserved on the plantation, and continue to exist in Black communities in the United States which is explored in chapter 1 .

Despite the negative effects of slavery, this text supports the perspective that Black Americans such as Gullah persons have maintained their African history, culture, and identity. Guthrie's Catching Sense who studied African Americans on St. Helena Island as a participant observer who utilized participant observation, open-ended interviews and constructed a household census of kinship and family patterns in the Gullah community. Chapter five acknowledges this text that describes kinship and family patterns on St. Helena Island plantation communities. Pollitzer's The Gullah People and Their African Heritage is referenced in chapters 1, 4 and 5 to address the historical and contemporary African culture of Gullah-speaking persons on the South Carolina Sea Islands. Cross's Gullah Culture in America delivers a historical and contemporary portrait of life on the Sea Islands for Black Americans who are members of the Gullah/ Geechee community of the South Carolina or Georgia Sea Islands. In chapters 5 and 7 , this book concentrates on Gullah/ Geechee persons who have managed to preserve the largest amount of Africanisms than any other Black community in the United States. 


\section{Linguistic Sources}

Ambrose Gonzales's Black Border: Gullah Stories of the Carolina Coast (1922) and Lorenzo Dow Turner's Africanisms in the Gullah Dialect (1949) are consulted throughout each chapter of this research as valuable linguistic sources containing two different research perspectives. Gonzales's Black Border introduces "A Gullah Glossary" that is a compiled list of seven hundred words and definitions from the Gullah language. The glossary is used in moderation because of Gonzales's comparative analysis research approach which disregarded Africanisms in the Gullah language. Gonzales believed that the Gullah language was a "jungle-tongue" that derived from American English. According to Wilbur Cross, "Gonzales based his dialogues on his many conversations with former slaves on his family's rice plantations. He tended to take most a condescending view of the Gullahs, referring to their speech as clumsy and the manner of presentation somewhat lazy or careless. ${ }^{, 6}$

Turner's Africanisms in the Gullah Dialect is also consulted as a linguist source. As the first African American linguist, Turner or the "Father of Gullah Studies" is recognized for his linguistic research on the Gullah community of the South Carolina Sea Islands. His research that connected the Gullah language to African countries including Sierra Leone, Liberia, and Guinea helped bridge more than a linguistic connection between Africans and Gullah-speaking persons. Turner used an African-centered perspective that consisted of a comparative analysis of West African words to Gullah words researched in West Africa. This perspective helped him to develop a phonetic alphabet. His research indicates that the Gullah language is an African survival derivative 
of West Africa. This text influenced notable sources such as Herskovits's The Myth and Joyner's Down by the Riverside. ${ }^{7}$

\section{Folkloric Sources}

The African folktales researched in this study are documented in a multitude of sources that consist of historical texts, collections of African folktales, slave testimonies, ethnographies, personal narratives, anthologies of literature, and scholarly journals. The two early collections of African folktales that are particularly referenced include: Joel Chandler Harris's Nights With Uncle Remus: Myths and Legends of the Old Plantation (1883) and Charles C. Jones's Myths of the Georgia Coast (1888). Other early collections are evaluated individually as having advantages and disadvantages. However, Jones's early collection is recognized as primarily benefiting the formal literary and cultural analysis used to conduct this research in chapter 6.

Harris's Nights With Uncle Remus is only consulted to observe the early version of the human tale "Origin of Species." Uncle Remus, the main character in the tale consulted in this research, is a fictional character based on male slaves Harris encountered while collecting African folktales on the Sea Islands. The advantages of Harris's collection include his interest in helping to preserve and publish the first book of African animal tales, and his belief that the animal tales were African in origin. ${ }^{8}$ However, this book contains many disadvantages that are acknowledged by scholars such as Sterling Brown in The Negro in American Fiction (1937), John D. Smith in The Unveiling of Slave Folk Culture, $1865-1920$ (1984), and Anthony L. Manna in “Br'er Rabbit Redux" (1992). These critics consider the effect of Harris's pro-slavery views on 
his presentation of African folktales and describe the personal and professional life of Harris as further highlighted in chapter 6.

According to Brown, Smith, and Manna, Harris was a contradictory, White, southern political journalist whose research almost always glorified slavery especially the systemic racial stereotypes that derived from it to support racial segregation and white supremacy which is evident in his "authentic" portrayal of the life of the slave. His collection was published during an era when there was an interest in folktales written in the Black dialect that were considered humorous. Harris's exaggeration of characters and their speech patterns was criticized as lacking authenticity and supporting minstrelsy. Harris's manipulation of the vernacular material is evident in Nights With Uncle Remus that is analyzed in chapter 6 . Research has proven that Harris altered elements of the tales including the speech patterns of Uncle Remus because he was unable to translate the Negro dialect. In spite of Harris's intentions, his collection was highly debatable since the animal and human tales failed to authentically portray slave life on the plantation, and discuss racial issues. ${ }^{9}$

Harris's collection presents challenges that many researchers face. Manna explains that Harris's folklore material teaches researchers a lesson about one's methodological approach to collecting and publishing folklore material especially in regard to its oral and written interpretation. ${ }^{10}$ Although criticized for his faulty research, Harris presumed to publish a new collection of African folktales. Even though he had run out of folklore material, to save his reputation, he consulted a friend, Charles C. Jones to find out if he knew anyone who collected African folktales. Jones took the opportunity to collect African folktales himself. He published, Myths of the Georgia Coast (1888). 
Brown describes the professional relationship between folklorists, Harris and Jones:

Harris recorded some of the folk-lore of the 'salt-water' Negroes with success, but it remained for Charles C. Jones to do the fuller job in Negro Myths from the Georgia Coast (1888). These tales are worthy to stand by those of Uncle Remus and, lacking the editorializing are closer to the originals. They are told in the unique lingo of the rice-field and sea island Negroes."

Jones's Myths of the Georgia Coast is known as "one of the earliest and most enigmatic collections of coastal African American folklore." ${ }^{2}$ Six animal tales examined for this research are from Jones's collection. These tales include: “How Come Buh Alligator Nebber Sleep Fur From De Ribber Bank," "Buh Tukrey Buzzud An De Rain,"“Buh Lion An Buh Goat," "De Eagle An Eh Chillun," "Chanticleer An De BanYad Rooster," "Buh Roccoon An Buh Possum." There are many advantages to the book. First, there is an interest in preserving African folktales. Second, the tales are told in the Gullah language that is reflective of the area where he collected the tales. Third, the tales authentically portray the perspective of the community who shared the tales. Fourth, the tales are mostly animal tales. Fifth, a few of the tales end with an emphasis on moral lessons and cultural values. ${ }^{13}$ However, the disadvantages of the book can be traced to Jones's paternalistic attitudes and identity as a privileged White man. A scholar who acknowledges Jones's shortcomings is Susan Millar Williams.

Jones was born into a religious family that owned several rice and cottonproducing plantations with more than one-hundred African slaves in Georgia. It is assumed that with his family, he also encouraged paternalism between the slave and slaveholder. This is problematic because it is believed that Jones went back to the plantation or plantations owned by his family on the Georgia Sea Islands to collect these 
tales. Although it is asserted that his belief in paternalism infuses a few of the tales, there is no evidence where Jones retrieved the tales. Regardless of these assumptions, William's believes, "his personal history made him one of the only people both qualified and motivated to compile such a collection in the 1880 s." ${ }^{14}$

Jones's collection consists mostly of animal tales but with a few tales that incorporate both animal and human characters that circulated among the newly emancipated persons on the Georgia and South Carolina Sea Islands. This collection is broadly consulted because of its child-sensitive tales. Jones's collection includes different tales that were used to impart a variety of lessons in socializing children on the plantation. These tales have managed to retain moral lessons and cultural values opposed to other collections of African folktales that are obscure. ${ }^{15}$ According to Susan Millar Williams, "Although scholars continue to discover modern variants of these tales, the versions Jones transcribes in the 1880 s are now regarded as a kind of window through which we can peer backward to the oral traditions of an even earlier time." ${ }^{16}$ The acknowledgement of Jones's collection is most important since a majority of the tales analyzed in this research are from his collection. However, there are three folktales used in this study that were not collected by Harris nor Jones: "Den To De Fiah," "John Saves Old Master's Children," and "All God's Chillun Had Wings."

Harris and Jones's collections of African folktales contain the earliest examples of surviving African folktales on the Sea Islands. However, Jones's collection is most important to this research because it provided folklore materials for more recent compilations of the animal tales in Jones's collection with one from Harris's collection. These recent collections include: Langston Hughes and Arna Bontemps's Book of Negro 
Folklore (1958), Zora Neale Hurston's Mules and Men (1969), Harold Courlander's Afro American Folklore: The Oral Literature, Traditions, Recollections, Legends, tales, Songs, Religious Beliefs, Customs, Sayings and Humor of Peoples of African Descent in the Americas (1976), Roger Abrahams's Afro-American Folktales: Stories From Black Traditions in the New World (1985), Virginia Hamilton's People Could Fly (1985), Steven Barboza's The African American Book of Values: Classic Moral Stories (1998), and Daryl Cumber Dance's From My People: 400 Years of African American Folklore (2002). These sources provide not only variations of these tales from Jones's and Harris's collection, but other animal and human tales collected on the Sea Islands. These tales are retold in the Gullah language as well as in African American Vernacular English (AAVE). Courlander's collection is mostly referenced to present tales in Jones's collection because AAVE is a familiar language for many African Americans.

The early and recent adaptations of African folktales on the Sea Islands aid this research. Hughes and Bontemps's Book of Negro Folklore offers the same early version of "Why Br' Gator's Hide Is So Horney" documented in Jones's text. Hughes and Bontemps's text also provides an early version of "Den To De Fiah" and "All God's Children Had Wings.” This last tale was told by Caesar Grant, a resident of Johns Island on the South Carolina Sea Islands. Hurston's Mules and Men offers an early version of "How the "Gator Got Black," Why Negroes Are Black, and "Member Youse a Nigger." Courlander's Afro American Folklore, retitled this last tale, “John Saves Old Master's Children." His text provides early, adapted, and recent versions of several of the tales documented by Jones and Harris that are written in AAVE. These tales include: "The Eagle and His Children," "You Never Know What Trouble Is Until It Finds You," 
"Chanticleer and the Barnyard Rooster," "Buh Lion and Buh Goat," "Buh Turkey Buzzard and the Rain," and "Buh Raccoon and Buh Possum." Courlander offers an adapted and recent version of Harris's human tale, "Origin of Species," that he entitled, "Origin of the Races." His text also offers recent versions of the human tales, "Den To De Fiah," "John Saves Old Master's Children," and "All God's Chillun Had Wings." Courlander's text is referenced as a recent collection of folklore that re-presents the animal tales in Jones's early collection. Abrahams's The African American Book of Values provides an adapted and recent version of "You Never Know What Trouble is Until it Finds You" that is written in AAVE. Hamilton offers an adapted version of "Bruh Alligator Meets Trouble" and "The People Could Fly." Dance's From My People provides an adapted and recent version of "De Eagle an' His Chillun" and "Buh Lion an' Buh Goat." Linguistically, this adaptation is closer to Jones's tale, and is the easiest to read. Barboza's The African American Book of Values offers an oral testimony from two islanders who were interviewed in an oral history project. These persons recalled an earlier version of "The People Could Fly" that was entitled "The Flying Africans." The folktales used for this research include "De Eagle An Eh Chillun," "Buh Lion and Buh Goat, "Buh Turkey Buzzard and the Rain," "Buh Raccoon and Buh Possum," "You Never Know What Trouble Is Until It Finds You," "Chanticleer and the Barnyard Rooster," "Origin of the Races," "John Saves Old Master's Children," "Den To De Fiah," and "The People Could Fly."

This research relies on several primary and secondary sources that offer a sociocultural historical perspective to help explain the function of African folktales within the slave community and contemporary Gullah community. These sources present 
background research on the historical and contemporary function of African folktales that educate and socialize Gullah children. The next chapter focuses on the methods used to conduct this study. 


\section{CHAPTER II}

${ }^{1}$ Melville J. Herskovits, The Myth of the Negro Past (Boston, MA: Beacon Press, 1958). 272-273.

${ }^{2}$ Margaret Wade-Lewis, Lorenzo Dow Turner: Father of Gullah Studies (Columbia, SC: University of South Carolina Press, 2007). 189.

${ }^{3}$ David Evans, "The Reinterpretation of African Musical Instruments in the United States" in The African Diaspora: African Origins and New World Identities, ed. Okpewho, Isidore, Carole Boyce Davies, Ali A. Mazrui (Bloomington, IN: Indiana University Press, 1999). 381.

${ }^{4}$ Evans, "The Reinterpretation of African Musical Instruments in the United States," 379.

${ }^{5}$ Ambrose E. Gonzales, The Black Border: Gullah Stories of the Carolina Coast (Columbia, SC: The State Company, 1922). 17.

${ }^{6}$ Wilbur Cross, Gullah Culture in America (Westport, CT: Praeger, 2008). 136; Lewis, Lorenzo Dow Turner, 90-91.

${ }^{7}$ Joko Sengova, "My Mother Dem Nyus to Plan' Reis: Reflections on Gullah/Geechee Creole Communication, Connections, and the Construction of Cultural Identity," ed. Afro-Atlantic Dialogues: Anthropology in the Diaspora (Santa Fe: New Mexico: School of American Research Press, 2006). 218219; Cross, Gullah Culture in America, 133; Lewis-Wade, Lorenzo Dow Turner, 125-202.

${ }^{8}$ Stella B. Brookes, Joel Chandler Harris: Folklorist (Athens, GA: University of Georgia Press, 2009). 23; Hugh T. Keenan, "Joel Chandler Harris and the Legitimacy of the Reteller of Folktales," in Sitting at the Feet of the Past: Retelling the North American Folktales for Children, ed. Gary D. Schmidt and Donald R. Hettinga (Westport, CT: Greenwood Press, 1992). 84.

${ }^{9}$ Although Harris's collection of tales was collected on Turnwold Plantation in Eatonton, Georgia, an area where the Black dialect was very similar to American English, he transcribed the tales in an exaggerated rendering of the dialect. Susan Millar Williams, foreword to Gullah Folktales from the Georgia Coast, by Charles C. Jones (Athens, GA: University of Georgia Press, 2000). 21; Williams, foreword to Gullah Folktales from the Georgia Coast, 21. National Park Service, Low Country Gullah Culture Special Resource Study (Atlanta, GA: NPS Southeast Regional Office, 2005). 59; John D. Smith, The Unveiling of Slave Folk Culture, 1865-1920 21, no. 1 (Bloomington, IN: Indiana University Press, 1984). 50; Sterling Brown, The Negro in American Fiction (Washington, D.C.: The Associates in Negro Folk Education, 1937). 57; Anthony L. Manna, "Br'er Rabbit Redux ed. Gary D. Schmidt and Donald R. Hettinga in Sitting at the Feet of the Past: Retelling the North American Folktales for Children, ed. Gary D. Schmidt and Donald R. Hettinga (Westport, CT: Greenwood Press, 1992). 96; Smith, The Unveiling of Slave Folk Culture, 1865-1920, 51; Brown, The Negro in American Fiction, 53; Ibid., 85; Keenan, "Joel Chandler Harris and the Legitimacy of the Reteller of Folktales," 86.

${ }^{10}$ Manna, "Br'er Rabbit Redux," 94.

${ }^{11}$ Brown, The Negro in American Fiction, 58.

${ }^{12}$ Williams, foreword to Gullah Folktales from the Georgia Coast, 11.

${ }^{13}$ Ibid., 11-23.

${ }^{14}$ Ibid., 12-23.

${ }^{15}$ Harold Courlander, Afro American Folklore: The Oral Literature, Traditions, Recollections, Legends, tales, Songs, Religious Beliefs, Customs, Sayings and Humor of Peoples of African Descent in the Americas (New York, NY: Marlowe \& Company, 1976). 487.

${ }^{16}$ Williams, foreword to Gullah Folktales from the Georgia Coast, 11. 


\section{CHAPTER III}

\section{METHODOLOGY}

This methodology chapter provides a qualitative, socio-cultural historical approach that focuses on the development of Black cultural space which is a contribution of this thesis, and its influence on African folktales in the Gullah community of the South Carolina Sea Islands in the United States. This research is an exploration of the historical and current function of African folktales that impart moral lessons and cultural values to educate and socialize Gullah children. This research relies on primary and secondary sources including historical, socio-cultural, linguistic, and folkloric to address two questions:

1. What factors existed during the antebellum era which created Black cultural space that would have permitted the continuation of folktales over time?

2. What moral lessons and cultural values were conveyed by African folktales directed at children during the time of slavery and in contemporary society among the Gullah community on the South Carolina Sea Islands?

In an effort to reconstruct Black cultural space, this research relies on sources that detail the culture that shaped the slaves. For example, three eras of the trans-Atlantic slave trade are used as a chronological foundation to guide the history of South Carolina during and after the antebellum period. ${ }^{1}$ In the historical and contemporary recognition of African folktales in the Gullah community, the theories of audience reception and 
interpretive communities are discussed to explain how the tales are understood across predominately African American communities. The following literary critical approaches are appropriate for assessing the function of animal and human tales in this research: formalism, new historicism, and semiotics or discourse analysis. These approaches offer a close reading of the tales as they have managed to retain its educational function in African American communities.

\section{Etymology and Nomenclature}

Although this research concentrates on African Americans who identify as members of the Gullah community on the South Carolina Sea Islands, African Americans who identify as members of the Geechee community on the George Sea Islands are acknowledged. As a result, it is important that the theories surrounding the etymology of the terms Gullah and Geechee are considered. According to African American linguist, Lorenzo Dow Turner, the term Gullah referred to a slave or African person from Angola. Other researchers believed the term Geechee referred to African Americans living near the Ogeechee River of Georgia. ${ }^{2}$

This research uses the racial categories consistent with the primary and secondary sources consulted. In older texts such as those by Gutman, Wood, and Rose, the key racial categories used to identify this population on the South Carolina Sea Islands include African, slave, contraband, and Negro. For example, contraband refers to persons of African descent on the South Carolina Sea Islands who were held in some form of captivity with a problematic legal status during the Reconstruction era. ${ }^{3}$ In new texts such as those by Guthrie and Wilkerson, modern versions of nomenclature are used to 
reference racial categories. In these texts, persons of African descent are classified as Colored, Black, African American, Gullah, Gullah persons, and Gullah-speaking persons depending on the historical time-frame acknowledged. For example, Black is a general racial category that could include much of the African Diaspora. The racial category, African American is more specific to persons of African descent who self-identify as American. Despite the ignorance of many researchers who identify this population as "Gullah" or "the Gullah," this research uses politically correct racial categories such as African, Black, African American, Gullah persons, Gullah-speaking persons, and Gullah community to describe persons of African descent who are members of the Gullah community on the South Carolina Sea Islands not as a tribe but as a cultural group that identifies as African American.

\section{Overview}

The advantages and disadvantages of using primary and secondary sources in the form of published books, diaries, articles, and journals are explained in this qualitative study. These sources explicate the function of African folktales using a socio-cultural historical lens within the literary and cultural analysis offered in this research. Although the social context in which these tales are presented in early collections of folktales has changed, the lessons imparted from the African animal and human tales on the plantation remain pertinent providing these tales are recently published collections of folklore that offer adapted versions of early tales. 


\section{Historical Sources}

This research uses historical sources such as Herbert Gutman's The Black Family in Slavery and Freedom, 1750-1925 (1976) and Charles Joyner's Down by the Riverside: A South Carolina Slave Community (1984) to describe slave life on South Carolina Sea Islands plantations. In chapter 4, Gutman's text is briefly used to discuss the stability of the slave family on Good Hope plantation. This chapter concludes with a brief description of plantation life between 1808 to the eve of the Civil War that leads into a discussion of the slave community's status in the 1860 s prior to and during the Civil War and Reconstruction era. However, in chapter 5, this text is used more thoroughly to reference the naming practices, marriage, and the presence of both parents on the plantation. For example, the birth register list which is a rare historical record includes

over 200 names of slave children and parents, the number of births, and the ages of the slaves, the length of marriage, and the number of children in the household to explain the conservation of kinship and family in the slave community. Gutman's analysis of the family system during slavery provides a contemporary understanding of the Gullah family that exists today. Using this data, it is asserted that due to the cohesion of the slave family, African cultural traditions such as folktales did not die during the antebellum era but were passed generationally to exist today.

In chapters 4 and 5, Joyner's text explains that during slavery, African folktales were used to encourage resiliency on South Carolina Sea Islands plantations. Using this text, this research assumes that a version of a tale can be subject to analysis and interpretation to reveal the surrounding culture. Gutman's and Joyner's sources explore how tales adapted to life on the plantation. Adaptation in the tales reflects the changing 
patterns in Black Americans' lives and the shift from slavery to contemporary racism. An in-depth examination of three factors including the influx of African slaves, White absenteeism, and the task system discussed in these historical sources help present the conditions of slavery under which Black cultural space emerged on the plantation to contribute to the preservation of African cultural traditions that include folktales in Gullah communities of the South Carolina Sea Islands.

\section{Socio-Cultural Sources}

The moral lessons and cultural values imparted from the African folktales that were used on the plantation and remain important in the contemporary Gullah community are observed throughout this research. Focusing on the home and community, two sources were used to help explain the presence of kinship and family patterns throughout the South Carolina Sea Islands: Lawrence Levine's Black Culture and Black Consciousness: Afro-American Folk Thought from Slavery to Freedom (1977) and Patricia Guthrie's Catching Sense: African American Communities on a South Carolina Sea Island (1996). In chapter 6, Levine's historical and contemporary discussion of African folktales is used in weighing the importance of the tales in Black communities including the Gullah community. Using this text, it is asserted that African folktales that reflect the lives of Black persons teach lessons about survival.

Guthrie's text on family structure on St. Helena Island on the South Carolina Sea Islands is used in chapter 5 to present a historical and contemporary description of kinship and family structure within the Gullah community. This research focuses on the presence of cultural traditions in the Gullah community. 
Levine's and Guthrie's texts indicate that African cultural traditions such as folktales are currently used to educate and socialize Gullah children just as they were used on the plantation. Using these texts, this research observes the multiple meanings of African folktales as representations of the social conditions experienced by Gullah persons.

\section{Linguistic Sources}

Ambrose Gonzales's The Black Border: Gullah Stories of the Carolina Coast (1922) and Lorenzo Dow Turner's Africanisms in the Gullah Dialect (1949) are two linguistic sources consulted throughout this research. Gonzales is referenced to better understand early and recent versions of African folktales written in the Gullah language. This source provides "A Gullah Glossary" that was compiled during his research on the South Carolina Sea Islands. The glossary is used to decipher idioms and meaning from historical and contemporary versions of the tales. ${ }^{4}$ This research relies on this source to grasp frequently used, and even obscure, words, and phrases at the time when these tales were collected. Although beneficial to the literary and cultural analysis of the African folktales as discussed in chapter 6, this glossary is used in moderation because Gonzales believes that the Gullah language consists mostly of borrowed English terms and a small number of African terms. However, Turner's text is referenced to better understand the Gullah language from an Afrocentric perspective. ${ }^{5}$ Turner's source is used for its phonetic alphabet that helped to decipher Gullah words infused within early versions of the African folktales studied in chapter 6. 


\section{Folkloric Sources}

This research observes two early collections of African folktales: Joel Chandler Harris's Nights With Uncle Remus: Myths and Legends of the Old Plantation (1883) and Charles C. Jones's Myths of the Georgia Coast (1888).This research uses one human tale from Harris's text and six animal tales from Jones's text present on the Sea Islands during the antebellum era. However, due to the stereotypical portrayal of African Americans in Harris's collection, the tales from Jones's early collection are primarily consulted. Harold Courlander's Afro American Folklore: The Oral Literature, Traditions, Recollections, Legends, tales, Songs, Religious Beliefs, Customs, Sayings and Humor of Peoples of African Descent in the Americas (1976) is consulted as a recent collection of folklore. This text is comprised of animal and human tales collected by Jones and Harris. Courlander's collection also includes tales collected by other early folklorists including Langston Hughes and Arna Bontemps's Book of Negro Folklore (1958), Zora Neale Hurston's Mules and Men (1969), Roger Abrahams's Afro-American Folktales: Stories From Black Traditions in the New World (1985), Virginia Hamilton's People Could Fly (1985), and Daryl Cumber Dance's From My People: 400 Years of African American Folklore (2002).

Courlander's text offers the following early, adapted, and recent versions of the animal and human tales chosen for this research: "De Eagle An Eh Chillun," "Buh Lion and Buh Goat, "Buh Turkey Buzzard and the Rain," "Buh Raccoon and Buh Possum," "You Never Know What Trouble Is Until It Finds You," "Chanticleer and the Barnyard Rooster," "Origin of the Races," "John Saves Old Master's Children," "Den To De Fiah," and "The People Could Fly." Several early versions of these tales have been linguistically 
modified to reflect a modern version of the Gullah language or African American Vernacular English (AAVE). For the purpose of this research, these tales are tracked in other sources to illustrate that no matter the linguistic translation, including duplication in the other anthologies, the tales' content retains the same structure, meaning, and overall, function-imparting lessons and values. This is evident in new collections of folktales that re-present animal and human tales documented in early collections. For example, Jones's early collection of folktales is adapted in Courlander's new collection of folktales.

Courlander translates the animal tales from the Gullah language to modern versions of AAVE.

In this research, the content of these tales are examined as understandable for both children and adults. ${ }^{6}$ These tales detail lessons specific to the rearing of children. These tales present a "code of conduct" to prepare children to overcome obstacles such as racism and oppression while teaching children about their African heritage. Steven Barboza's The African American Book of Values: Classic Moral Stories (1998) is useful to this research because it focuses on the tales' function in teaching moral lessons and cultural values that persist to encourage Gullah children to appreciate their African heritage. These folkloric sources were relied on to conduct a formal literary analysis and cultural analysis used to reconstruct aspects of the relevant social history, namely moral lessons and cultural values pertaining to particulars of Gullah life.

This study concentrates on African folktales used to educate and socialize children about parental guidance, racial identity, responsibility, and race relations. These tales are used to help children appreciate their African heritage and to fight against racism and oppression. Lessons about religion and marriage are excluded from this research in 
order to highlight lessons that deal with child sensitive issues to help children rise above adversity. Generally, most moral lessons and cultural values intended for children are presented in the form of animal tales that use an imaginary world to frame realistic issues that children can comprehend. ${ }^{7}$

There are a multitude of African tale types and motifs; however, this study focuses on the cautionary, escape, humorous, and trickster-and their lessons. In chapter 6, the critics who examine survival humor in Harris and Jones's collections include: Constance Rourke's American Humor: A Study of the National Character (1931), Sterling Brown's The Negro in American Fiction (1937) and Ralph Ellison's Shadow and Act (1964). These literary critics unpack the controversial, personal and professional lives of Harris and Jones. These criticisms describe Harris's collection as supportive of minstrelsy and cultural insensitivity. As a result, this thesis primarily consults Jones's early collection of folklore and Courlander's recent collection of folklore.

Other critics include: John W. Roberts, From Trickster to Badman: The Black Folk Hero in Slavery and Freedom (1989), Anthony L. Manna, "Br'er Rabbit Redux" (1992), Hugh T. Keenan, "Joel Chandler Harris and the Legitimacy of the Reteller of Folktales" (1992), and John W. Roberts, "African American Diversity and the Study of Folklore" (1993). In chapters 1 and 6, these critics focus on the impact of survival humor particularly in the Black community. Survival humor or the use of laughter is explained as a positive and negative technique used to deal with obstacles. The contradiction of this technique is interpreted in cautionary tales such as "Buh Raccoon and Buh Possum." Criticism on survival humor explains it as a trickster trait both in folktales and the lives of Black Americans. 
Although there are negative and positive aspects of using printed folktales in these two collections, the most important feature of this research focuses on the lessons imparted from the tales' content. This research explores the historical function of African folktales using a literary and cultural analysis. Categories for these tales, based on their lessons and cultural values are: parent $\&$ child responsibilities, racial identity \& White privilege, human interactions, and building character traits such as courage, bravery, and resiliency. For each category, this research offers a summary, as well as an analysis and interpretation of two or three tales. The tales' moral lessons and cultural values are derived from this analysis.

\section{Research Design: Literary and Cultural Analysis}

A qualitative research method was used to conduct this study to reconstruct the social contexts in which the African folktales references in this thesis mostly likely circulated. With published collections of African folktales specific to the Sea Islands regions, this investigation theorizes the historical function of African folktales as a method to educate and socialize Black children in communities such as the Gullah community of the South Carolina Sea Islands. Moreover, this research largely consists of a literary and cultural analysis that uses theories of audience reception and interpretive communities, principally in chapter 6, to explore the folkloric exchanges among Gullah persons. These theories are used by other critics of folklore that include fairytales, parables, and folktales to emphasize the ways in which various communities interpret literature.

According to Jill P. May, audience reception theory that focuses on how the text 
is received by a particular community is interconnected with cultural experiences. ${ }^{8}$ Chapter 6 uses a literary and cultural analysis to evaluate this theory within a historical and contemporary context. In chapter 5, this theory is used to observe Gullah persons' historical and contemporary response to African folktales as a form of education and socialization. This theory highlights the importance of decoding the tales' content to understand its function in the rearing of Black children in America. Black parents use African folktales to teach children moral lessons and cultural values that will help them to learn about their African heritage while fighting oppression. From this theory, that focuses on the needs of the children derives the concept of interpretive communities that is considered in chapters 5 and 6 .

This study relies on Stanley Fish's theory of interpretive communities which is a branch of audience reception theory positing that a community of readers or auditors, because of shared experiences and frames of reference, construct a shared range of interpretive responses. ${ }^{9}$ In chapter 5, this theory validates the contribution of African folktales that helped to develop literacy on the plantation before formal schools were established. The theory of interpretive communities argues that the perceptions of literate persons are based on socially constructed assumptions shared within a community. This theory is considered in the discussion of kinship ties unique to Gullah communities throughout the Sea Islands. In chapter 6, this theory offers the ways in which the chosen tales reflect a historical and contemporary social context.

This research draws on general studies of literary critical approaches including formalism, new historicism, and semiotics or discourse analysis. These approaches evaluate the operative use of the tales acknowledged in this research. Formalism is used 
to explain the tales' content to extract historical and contemporary relevancy. Formalist theory began as an evaluation of linguistics. ${ }^{10}$ However, formalism evolved to focus on patterns, imagery, tone, and other elements in literature. This theory is at the foundation of the second research question. In chapters 5 and 6 , this theory is used with the investigation of the tales function on the plantation and in contemporary Black communities that include the Gullah community.

New historicism is used to survey a text and its relationship to social contexts that abandon previous hierarchies that are culturally insensitive. Using this theory in chapter 6, this research evaluates African folktales that have adapted to social conditions over time on the South Carolina Sea Islands. According to literary scholars, Stephen Greenblatt and Louis Montrose new historicism is explored within the various social hierarchies of power. New historicism draws attention to and challenges the power dynamics that breed inequality across race, gender, and class lines. This theory presents the ways in which oppressed African Americans including Gullah persons have used discourse to gain social power since slavery. For example, the hidden messages imbued in the African folktales offered the slaves power to act subversively on the plantation. ${ }^{11}$ Montrose writes that new historicism attempts "to resituate canonical literary texts among the multiple forms of writing, and in relation to the non-discursive practices and institutions." ${ }^{, 12}$ This theory is relevant to my study on African folktales because it investigates the historical context in which the tales are identified. The historical position of the tales is considered in the determination of the function of the animal and human tales' that were collected during the antebellum period in South Carolina.

In chapter 6, semiotics or discourse analysis is used to study the function of 
language and signs in the tales' content. In the folklore collections consulted for this research, each tale is evaluated on the basis of consistency in content and language. Semiotics or discourse analysis provides evidence that the tales' content that include the moral lessons and cultural values remain the same but the Gullah language in which the tales are told are modified to reflect the contemporary speech patterns of African Americans on the Sea Islands. These theories are used to explore African folktales' general and child sensitive content.

Moreover, this research uses an Afrocentric approach that focuses on the function and adaptation of African folktales consisting of a literary and cultural analysis. This analysis is modeled after that of John W. Roberts, a literary scholar and folklorist, who writes:

An Afrocentric approach to African American culture and folklore requires studying them as the reflection of a process that is not unique but influenced by factors similar to those which shape culture-binding and folklore creation in other groups. In other words, we must approach African American culture and folklore as a reflection of the beliefs, concerns and values of African Americans. ${ }^{13}$

Roberts describes a reconstructive perspective used to analyze culture and folktales that is examined in this study. His research "attempted not only to present a bird's eye view of the paths that students of black oral expressive culture have taken in arriving at conclusions about its origins, meanings, and functions, but also to highlight some of the underlying considerations that have informed their choices." Using an Afrocentric and reconstructive perspective, this research focuses on African folktales as a functional African survival. ${ }^{14}$ 
The literary and cultural analysis uses three approaches to comprehend the function of the tales. First, the animal and human tales are thoroughly read. A brief summation of each tale using a formalist approach is provided. Second, the symbolism of the characters, setting, and plot in the animal and human tales are analyzed. This examination consists of comparing and contrasting the past and present social conditions of the Gullah community using a new historicist approach. A diachronic analysis that concentrates on the impact of racism and oppression in both a historical and contemporary setting is used. Conclusions are drawn about the adaptation of African folktales, and its reflection of Gullah persons who created and transmitted the tales. To explore the adaptation of African folktales on the plantation, the animal and human tales are compared and contrasted. This research explains that the West African animal tales brought to America adapted to life on the plantation. These tales adapted by transforming from animal tales into human tales. Third, semiotics or discourse analysis is used to explore the hidden idioms and meanings within the tales that are relevant to their social contexts. The reading of the content of African folktales asserts that since slavery, these tales have functioned to educate and socialize Gullah children on the South Carolina Sea Islands.

\section{Research Demonstration}

As a demonstration of the formal literary and cultural analysis used to conduct this research, each animal and human tale is briefly summarized, analyzed, and interpreted. 


\section{$\underline{\text { Animal Tales }}$}

A. "De Eagle An Eh Chillun"

This tale is derived from Jones's Myths of the Georgia Coast. This tale focuses on the relationship between an Eagle and its Eaglets. The Eagle is a role model who teaches the Eaglets how to fly. The Eagle teaches the Eaglets to respect parental figures, to model responsibility, and to value a respectable work ethic. This tale explains the role of Black parents in modeling positive values such as responsibility, diligence, and perseverance to their children. These values prepare the child to foster a steadfast work ethic.

B. "Buh Turkey Buzzard and the Rain"

This tale is derived from Courlander's Afro American Folklore. This cautionary, escape, and humorous tale focuses on the life of Buh Turkey. Buh Turkey Buzzard is frustrated when it rains. Although he plans to shelter himself from the rain by building a house for protection, he is too lazy to follow-up with the plans. Buh Turkey Buzzard's traits of carelessness and contentment teach children the repercussions of being unprepared, counterproductive, and irresponsible. This cautionary tale is limited to this research because it indirectly teaches children how not to behave. As a result, depending on the interpretation, this tale could pose positive and negative consequences.

C. "Buh Raccoon and Buh Possum"

This tale is derived from Courlander's Afro American Folklore. This cautionary and humorous trickster tale describes two animals, Buh Raccoon and Buh Possum. The different perspectives and motivations of these characters are examined when Buh Raccoon observes how Buh Possum confronts obstacles. When Buh Possum surrenders to the dogs that terrorize him, Buh Raccoon asks why he chooses not to retaliate. Buh Possum explains that when the dogs tickled him he forgot to fight. Buh Possum's reasoning is based on the survival humor used in various communities including the Gullah community. Survival humor has its advantages and disadvantages. This tale describes survival humor as both a positive and negative response to dealing with obstacles.

D. "You Never Know What Trouble Is Until It Finds You"

This tale is derived from Courlander's Afro American Folklore. This cautionary trickster tale focuses on two animals, Bruh Rabbit and Bruh Gator. Bruh Rabbit tricks the privileged Bruh Gator into meeting "Trouble" to teach him a lesson about the oppressive impact of White privilege on the Black community. This discusses race and class disparity in the United States. This tale teaches children what it means to be Black in a racist America. 
E. "Chanticleer and the Barnyard Rooster"

This tale is derived from Courlander's Afro American Folklore.

This cautionary trickster tale describes the competitive relationship between two animals, Buh Chanticleer and Yellow Rooster, on a plantation farm. Buh Chanticleer is the strongest of the birds that include Yellow Rooster, a violent gang member. Although vicious, Yellow Rooster was afraid of Buh Chanticleer. Buh Chanticleer's prominent status as a leader with the best morning crow made Yellow Rooster envious. Yellow Rooster practices Buh Chanticleer's morning routine to gain respect and recognition. This angers Buh Chanticleer who seeks revenge by having Buh Fox, an enemy, to kill Yellow Rooster. Despite Buh Chanticleer's plan, he is also eaten. The motives of both animals teach the disadvantages of revenge and trusting an enemy. This tale details the consequences of negative competitiveness.

F. "Buh Lion and Buh Goat"

This tale is derived from Jones's Myths of the Georgia Coast. This escape trickster tale focuses on two animals, Buh Lion and Buh Goat. Buh Lion, one of the most physically powerful animals is in opposition to Buh Goat, an animal known for its physically small stature. Buh Lion approaches Buh Goat who is chewing while enjoying the day. This frustrates Buh Lion who enjoys being in control and overpowering other animals. Buh Lion inquires about the food Buh Goat is chewing so that he feels in control. Rather than remain afraid, the courageous Buh Goat stands up to Buh Lion. As a brave animal, Buh Goat gains respect. This tale teaches children the value of bravery and courage in the midst of obstacles.

\section{$\underline{\text { Human Tales }}$}

G. "Origin of the Races"

This tale is derived from Courlander's Afro American Folklore. This cautionary tale features Uncle Remus, a male slave who teaches a White child about racial identity. Uncle Remus explains that the first humans were Black until a magical pond was discovered. This pond had the power to turn Black people White. Everyone wanted to access this pond even if it meant only dipping in one's palms, which is what Uncle Remus did. Uncle Remus teaches about the construction of racial identity. This tale defines race during the antebellum era.

\section{H. "Den to De Fiah"}

This tale is derived from Hughes and Bontemps's Book of Negro Folklore. This cautionary and escape trickster tale focuses on the lives of two male slaves, Uncle Jack and Jim, and their relationship with the slaveholder, Master Sipsey. When Master Sipsey tries to catch and whip Uncle Jack for his rebellious behavior of not completing his tasks, loyal Jim helps devise a plan, even though both male slaves considered one another friends. Jim 
goes through with his plan unsuccessfully with Uncle Jack escaping future whippings after throwing Master Sipsey in the bonfire with minor burns. This tale discusses interracial and intra-racial human interaction. It also provides two different perspectives on the resistance or acceptance racial oppression.

I. "John Saves Old Master's Children"

This tale derived from Hurston's Mules and Men, and was adapted in Courlander's Afro American Folklore. This escape and trickster tale describes the life of John, a male slave on Old Master's plantation. John saves Old Master's children from drowning in a lake. With this deed, John is promised his freedom upon filling the barn with a year worth of crops. Once John is granted his freedom, Old Master tries to verbally discourage him from leaving the plantation by referring to him as a "good nigger." However, John continues to walk toward Canada. John's quest for freedom teaches a lesson about duality and perseverance.

J. "The People Could Fly"

This tale is an adapted version of storyteller Caesar Grant's "All God's Children Had Wings" collected in Hughes and Bontemps's Book of Negro Folklore. This study uses an adapted version of the tale documented in Hamilton's People Could Fly. This cautionary, escape and trickster tale focuses on a large cotton-producing plantation where African slaves are physically weakened by the harsh conditions. A few slaves fall from weakness and are severely lashed to work harder and faster. When the pain is unbearable, an older male slave speaks in a foreign tongue to those who have fallen. From this secret language, many slaves remember the words but others do not. Those who remember, have the power to fly from the plantation back to Africa. Those who can't remember, or were never taught to fly, are encouraged to run. This tale presents a realistic description of life on the plantation on the South Carolina Sea Islands. This tale documents the power of preserving African heritage.

This literary and cultural analysis treats the chosen African animal and human tales. These tales are evaluated on the basis of character/ trickster role, environment, thematic pattern, problem and solution (conflict resolution), and moral lesson. The main goal of the analysis is to observe and evaluate character motivation which translates into the motivation of the Black person. The tales' content presents moral lessons and cultural values used to encourage children to be independent, brave, and resilient. Although these 
lessons are considered general knowledge in Black communities such as the Gullah community, these lessons are magnified due to the impact of institutional racism.

\section{Cultural Change and African Folktales}

Anthropologist Melville J. Herskovits's research is used to help dispel the belief that persons of African descent are devoid of a distinct African heritage. His research on cultural change in the "Memorandum for the Study of Acculturation" (1935) refines the conditions under which three factors contribute to the development of a creolized community on the Sea Islands. The memorandum helps to explain that preserved African folktales are African in origin, and function to educate and socialize children in the

Gullah community. ${ }^{15}$ These factors facilitate a discussion of the historical and current adaptation and transformation of African folktales on the South Carolina Sea Islands explored in this research.

Herskovits's theory of cultural change addresses three specific factors that help to facilitate the retention of African folktales. The first factor is the oppressive relationship between slaveholders and slaves given the establishment of slavery in the United States. The slaveholders brought African slaves to the South Carolina Sea Islands to work on plantations. In Herskovits's analysis of acculturation, he identified five types of contacts between culture-carriers. The slaveholder-slave contact represents all fives contacts. This encounter is hostile and marked by inequality. The slave community represents the cultural group that must learn to adapt and survive on the plantation while exposed to a foreign culture (i.e. White persons). The second factor refers to the situations in which acculturation occurs. According to Herskovits, acculturation can occur involuntarily or 
voluntarily, and in the absence or presence of inequality. Slave communities on Sea Islands plantations involuntarily adapted to life on the plantation under unjust conditions. The conditions of slavery contributed to the occurrence of acculturation on the plantation. The third factor is the processes under which acculturation develops. Herskovits explained that culture-carriers select, determine, and integrate traits that are either accepted or resisted by the receiving culture. ${ }^{16}$

Acculturation is the study of cultural contact and his theory examines retained cultural traditions. Herskovits described the process of acculturation as a two-way street, benefiting cultural groups that undergo modification after being in contact with other cultures. Diffusion is also a factor in acculturation. Diffusion is defined as a process of acculturation that helps explain the presence of African folktales in the Gullah community. Herskovits and Levine agree that diffusion is the continuous transmission of information from one culture to another. The exposure to different cultures impact the process of diffusion. The exchange of cultural traits presents three results that are documented in the memorandum as acceptance, adaptation, and reaction. These outcomes facilitated the preservation of African cultural traditions including folktales on the plantation. For example, on the plantation, characters in animal and human tales secretly reflect the slave's duality and "double consciousness." The slaves used these tales to constantly test and manipulate authority to overcome oppressive obstacles on the plantation. W. E. B. Du Bois describes "double consciousness" as a form of duality in which one learns to negotiate between two different worlds in order to survive. The trickster figure taught slave children to accept and reject the slaveholder's European American heritage. Biculturalism helped the slave understand their culture as well as the 
slaveholder's culture. As a result, trickster characters educated and socialized slave children to learn the ways of the slaveholder and to use trickery to overcome oppression. $^{17}$

In theory, acculturation is the process of incorporating cultural elements from other cultures into one's own, which suggests that Gullah-speaking persons acculturated rather than assimilated into European American heritage. This theory helps support the evidence that African American communities have culturally adapted to European American culture while maintaining their resilient African-rooted identity. Herskovits believed that African Americans psychologically persevered. ${ }^{18}$ Herskovits's theory of cultural change acknowledges the retention and reinterpretation of African folktales. ${ }^{19}$

Despite the ramifications of cultural change, African heritage is at the center of the Gullah community. Herskovits studied the circumstances of slavery that contributed to the adaptation of African folktales on the plantation where these tales were used to mirror the lives of slaves on the plantation. One of the cultural adaptations that Herskovits acknowledged was the preservation of African folktales which he classified as an Africanism. Also referred to as African survivals, these tales are retentions of African cultural traditions that fully function in and for Black cultural groups, such as the Gullah community. African folktales incorporated other cultural elements and adapted to social conditions including life on the plantation by transforming from animals indigenous to West Africa to animals indigenous to the Sea Islands. The animal characters became symbolic of the slave, and later, to the life of a contemporary Black person in America. ${ }^{20}$ Herskovits's research on cultural change and the presence of African folktales benefits 
the purpose of this thesis which considers the development of Black cultural space that created a creolized Gullah community on the South Carolina Sea Islands.

\section{Facts and Figures}

This research relies on the U.S. Census Bureau for demographical data on South Carolina. Particularly, this research focuses on five of 16 South Carolina Sea Islands that include: Daufuskie Island, St. Helena Island, Hilton Head Island, Sullivan's Island, and Johns Island. These islands were chosen to explain how the in-migration of Whites and the development of the tourism industry on the islands have contributed to the outmigration and exploitation of African Americans. In the appendix of this research, two tables present a current of the White and African American population on these five Sea Islands. Table 1 refers to the 2000 U.S. Census Tracts of South Carolina data to specifically locate the presence of African Americans on the Sea Islands. Table 2 refers to the 2010 U.S. Census data on South Carolina to provide the most recent demographic data on the Sea Islands. These five Sea Islands that once had a majority African American population now have a large White population that is contributing to the encroachment of Gullah communities throughout the Sea Islands. In the appendix, a map of the South Carolina Sea Islands is provided.

\section{Statement of Problem}

Notwithstanding efforts at preserving some of their inherited African customs and cultures, including the tradition of storytelling, it was difficult for the Gullah community or any other African community in America to conserve such a large amount of African 
cultural traditions including African folktales. Due to the harsh reality of life as a slave, the transmissions of these oral folktales were forbidden on the plantations resulting in the loss of a number of tales. Although this is true in many circumstances, there remains a significant collection of African folktales today as evident in the familial relationships between slaves who were born into slavery on the plantation and those who were born in Africa.

This research was limited by time constraints and the inability to travel to the South Carolina Sea Islands which were not feasible options. If these options were available, the Human Subjects and Institutional Review Board (IRB) could have been utilized to conduct research on African folktales told in the home and community of Gullah-speaking persons which would have verified the extent to which the tales explored in this study are still told in the Gullah community on the Sea Islands. However, due to this limitation, this research does not include oral versions of tales as they are shared among Gullah-speaking persons today. Moreover, with additional time and travel, this research would have concentrated only on early and recent collections of folklore that identify the specific geographic location (noted towards the end of each tale) of animal and human tales that derived from distinct Sea Islands plantations. This focus would have benefited the audience reception theory discussion that is highlighted to explain the historical and current function of folktales among Gullah communities on the South Carolina Sea Islands.

Perhaps the most challenging limitation of this research was the complete reliance on print sources. For example, due to Harris's problematic collection, Jones's folklore collection is primarily used as an early source. Jones's collection is especially important 
because it provides animal tales. However, this research compensates for the limitations of Harris's collection not only by focusing on animal tales in Jones's early collection, but on the modified versions of animal and human tales that include John-Master tales. Other folklore collections are consulted to evaluate the ways in which the tales' content remains the same but the language in which these tales are told change. Moreover, although it is legitimate to analyze collected tales, for they are one of the principal means by which we have access to this rich folkloric tradition, they are not necessarily the same versions persons in any given community heard, because the tales changed with the tellers and their circumstances. The folklore collections used for this research did not contain a large number of John-Master tales but rather human tales about marriage and religion. These sources led to an issue in finding a variety of John-Master tales.

Although these tales are appropriate in imparting moral lessons and cultural values, the genre of religion and intimate relationship tales have already been widely researched, and are many times lacking in child sensitivity. This research focuses on a smaller collection of animal and human tales that teach general moral lessons and cultural values about the human interaction between the slave and slaveholder. The small number of John-Master tales was a limitation resulting from the use of the folklore collections consulted for this research. Jones's collection consists of animal tales, and Courlander's collection consists of animal and human tales. Although Courlander's text provides a partial list of John-Master tales, his recent collection of these tales is considered.

This research was limited because majority of the African folktales did not specify or note the names of the plantations where particular tales circulated to teach lessons. Although a few of the tales specify the plantation from which these tales derive 
on the Georgia and/or South Carolina Sea Islands, the name of the plantations are unmentioned in majority of the tales examined in this research. Furthermore, the modicum of prior research published on contemporary kinship and family patterns in the Gullah community was also a limitation. Published sources that documented the plantations where these tales were told would have benefited this research. It would have given a direct view of moral lessons and cultural values as more exclusive to the social conditions of an individual plantation.

Finally, this research was limited because it indirectly acknowledges the contemporary function of African folktales as a method to educate and socialize Gullah children on the South Carolina Sea Islands. Although this is a limitation that is connected with the inability to travel to the Sea Islands, contemporary folklorists such as Courlander and others who re-resent the animal and human tales examined in this research provide evidence that the tales retain the same meaning content and message used to impart moral lessons and cultural values of resistance and perseverance.

This chapter provides the methods used to conduct this research. Primary and secondary sources were consulted to address the two research questions that focus on the development of Black cultural space and its influence on the retention of African folktales on the plantation. Literary criticism is offered to explain the educational function of the tales within a historical and contemporary context. The following chapter offers a historical account of Black presence and the development of Black cultural space on the South Carolina Sea Islands. 


\section{CHAPTER III}

${ }^{1}$ The three eras of the trans-Atlantic slave trade include the Early Period, 1716-1744, the Middle Period, 1750-1787, and the Final Period, 1804-1808. These historical periods are referenced in Margaret Washington. Creel's "A Peculiar People" Slave Religion and Community-Culture among the Gullahs (New York, NY: New York University Press, 1988). The eras are also referenced in Joseph Holloway's Africanisms in American Culture (1991).

${ }^{2}$ Virginia Hamilton, The People Could Fly: American Black Folktales (New York: Alfred A. Knop, 1985). 42; Joko Sengova, "My Mother Dem Nyus to Plan' Reis: Reflections on Gullah/Geechee Creole Communication, Connections, and the Construction of Cultural Identity," ed. Afro-Atlantic Dialogues: Anthropology in the Diaspora (Santa Fe: New Mexico: School of American Research Press, 2006). 214; Mary A. Twining and Keith E. Baird, "Introduction to Sea Island Folklife" Journal of Black Studies 10, no. 4 (1980): 397.

${ }^{3}$ Willie Lee Rose, Rehearsal for Reconstruction: the Port Royal Experiment (Indianapolis, IN: BobbsMerrill, 1964). 15.

${ }^{4}$ Ambrose Gonzales, The Black Border: Gullah Stories of the Carolina Coast (With a Glossary) (Columbia, SC: The State Company, 1922). 287.

${ }^{5}$ Wilbur Cross, Gullah Culture in America (Westport, CT: Praeger, 2008). 133.

${ }^{6}$ Terrell A. Young and Phyllis M. Ferguson, "From Anansi to Zomo: Trickster Tales in the Classroom." The Reading Teacher 48, no. 6 (1995): 490.

${ }^{7}$ Jan Carter-Black, "Teaching cultural competence: An innovative strategy grounded in the universality of storytelling as depicted in African and African American storytelling traditions." Journal of Social Work Education 43 no. 1 (2007): 42; William R. Bascom, "Four Functions of Folklore," in The Study of Folklore. ed. Alan Dundes (Englewood Cliffs, NJ: Prentice-Hall, Inc., 1965). 294; Bena R. Hefflin and Mary Alice Barksdale-Ladd, "African American Children's Literature That Helps Students Find Themselves: Selection Guidelines for Grades K-3," The Reading Teacher 54, no. 8 (2001): 814.

${ }^{8}$ Jill P. May, "Theory and Textual Interpretation: Children's Literature and Literary Criticism," The Journal of the Midwest Modern Language Association 30, no. 1/2 (1997): 81.

${ }^{9}$ Stanley Fish, There's No Such Thing As Free Speech: And It's a Good Thing, Too, Part 8 (New York, NY: Oxford University Press, Inc., 1994). 288-289.

${ }^{10}$ Terry Eagleton, Literary Theory: An Introduction, Anniversary ed. (Minneapolis, MN: University of Minnesota Press, 2008). 3.

"Eagleton, Literary Theory, 199; Dino Felluga, "Module on Stephen Greenblatt: On History," Introductory Guide to Critical Theory, last modified 2011.

http://www.purdue.edu/guidetotheory/newhistoricism/modules/greenblatthistory.html.

${ }^{12}$ Louis Montrose, "Renaissance Literary Studies and the Subject of History," English Literary Renaissance 16, (1986): 6.

${ }^{13}$ John W. Roberts, From Trickster to Badman: The Black Folk Hero in Slavery and Freedom (Philadelphia, PA: University of Pennsylvania Press, 1989). 11.

${ }^{14}$ Ibid., 4; Ibid., 220.

${ }^{15}$ Melville J. Herskovits and Frances S. Herskovits, The New World Negro: Selected Papers in Afroamerican Studies (Bloomington, IN: Indiana University Press, 1966). 149.

${ }^{16}$ Melville J. Herskovits, R. Redfield, and Ralph Linton, "Memorandum for the Study of Acculturation," American Anthropologist 38, (1935): 149-152.

${ }^{17}$ William S. Pollitzer, The Gullah People and Their African Heritage (Athens, GA: University of Georgia Press, 1999). 162. Charles Joyner, Down by the Riverside: A South Carolina Slave Community (Urbana, IL: University of Illinois Press, 1984). 175; John W. Blassingame, The Slave Community: Plantation Life in the Antebellum South, Revised and Enlarged Ed. (New York, NY: Oxford University Press Inc., 1972). 127186; W. E. B. Du Bois, The Souls of Black Folk (The Souls of Black Folk (Rockville, MD: Arc Manor, 1964). 12-17; Martha Sims and Martine Stephens, Living Folklore: An Introduction to the Study of People and Their Traditions (Logan, UT: Utah State University Press, 2005). 153; Charles Joyner, Shared Traditions: Southern History and Folk Culture (Urbana, IL: University of Illinois Press, 1999). 16; Willie Lee Rose, Rehearsal for Reconstruction: the Port Royal Experiment (Indianapolis, IN: Bobbs-Merrill, 1964). 136. 
${ }^{18}$ Herskovits and Herskovits, The New World Negro, 23.

${ }^{19}$ Herskovits, Redfield, and Linton, "Memorandum for the Study of Acculturation,"149-152; Jerry Gershenhorn, Melville J. Herskovits and the Racial Politics of Knowledge (Omaha, NE: University of Nebraska Press, 2004). 253-254, note 38; Herskovits, The Myth of the Negro Past, 10; Lawrence Levine, Black Culture and Black Consciousness: Afro-American Folk Thought from Slavery to Freedom (New York, NY: Oxford University Press, 1977). 444.

${ }^{20}$ Herskovits, Redfield, and Linton, "Memorandum for the Study of Acculturation," 149-152. 


\section{CHAPTER IV}

\section{THE HISTORICAL SETTING}

It has been said that those hapless occupants of slave ships carried nothing with them on their involuntary voyages from West African to the New World. This is not true. Though they were stripped of everything but their names, they carried indelible memories of their culture-music, folklore, language, art, and religion- to the Sea Islands. ${ }^{1}$

This chapter provides a historical analysis comprised of three eras of the transAtlantic slave trade to highlight those characteristics of slavery that facilitated the emergence of Black cultural space that influenced the maintenance of African folktales on South Carolina Sea Islands plantations. The purpose of this chapter is to illuminate the geography, the selection and contribution of slave labor from specific regions of West Africa, the isolation of the slaves, the role of the task system in creating Black cultural space, and the most prominent rice, indigo, and cotton plantations, while simultaneously examining the degree to which the slaves were able to retain and transform their African cultural heritage.

Thus, this chapter traces the West Africa origins of the Gullah community and their importation from different regions along the Atlantic from the Gambia, Senegal, Sierra Leone and Angola into the South Carolina Sea Islands through the trans-Atlantic slave trade. As the captives were removed from their homelands, they were transported with their inherited African cultural traditions; among them were folktales. These tales 
were transmitted through generations as oral narratives from Africa to North America. According to Daryl C. Dance:

Stripped of family and friends, every possible belonging, even language, name, and religion, the kidnapped Africans did manage to smuggle African folktales aboard the slave ships that transported them to America: Brer Rabbit and Brer Anancy, whom Guyanese author A.J. Seymour called 'the unregistered passenger[s] of the Middle Passage. ${ }^{2}$

\section{The Importation of Slaves into South Carolina}

The history of the importation of African slaves on the South Carolina Sea Islands is examined within three eras: the Early Period (1716-1744), during which the slave trade began a selective process for specific slaves along the West African coast thought to maximize the production of rice and indigo, culminating with the Stono Rebellion of 1739 conducted by Bantu-speaking slaves; the Middle Period (1750-1787), characterized by the spread of disease on the plantations, White absenteeism, the role of overseers and drivers, systems of production and the use of slaves in maritime labor all contributed to the emergence of Black cultural space; the Final Period (1804-1808), consists of the development of an autonomous African slave community during which the preservation of African heritage and the development of a distinctive Gullah cultural tradition can be seen. From 1670 to 1808 , African slaves who were thought most equipped for house or field labor on the rice, indigo, and cotton plantations were from Guinea, Senegambia, Angola, and Sierra Leone. ${ }^{3}$ After the international trade in slaves was outlawed in 1808 , the smuggling of African slaves from Sierra Leone into the rice, indigo, and cotton plantations of the South Carolina Sea Islands continued. This illegal trade was

supplemented by the inland slave trade. ${ }^{4}$ We begin with the founding of a New World by 
an early settler before this first period.

After Christopher Columbus mistakenly discovered the New World in 1492, the volume of trade in slaves expanded exponentially, igniting the mass movement of Africans into the Americas through the trans-Atlantic slave trade, which began in the early $16^{\text {th }}$ century. In 1526 , the importation and presence of the first Africans on the South Carolina Sea Islands began with a Spanish expedition from the West Indies. ${ }^{5}$ As early as the 1530's, English ships that had begun sailing along the West African coast began taking slaves from present-day Sierra Leone in the 1560's. By 1619, the first group of slaves sold in Virginia by Dutch traders is documented. Moreover, not long after the presence of this group of slaves, plans were made to develop slavery as an economic industry throughout the antebellum South. By 1631, a fort was built on the Gold Coast which led to the establishment of other forts in the Gambia and at Bance Island in Sierra Leone in the 1660's. By 1670, Charles Town, South Carolina was established as an English colony by settlers of the Barbados who developed and implemented a plantation system used throughout the Caribbean that was brought to South Carolina. Shortly afterwards, South Carolina was founded as one of the original thirteen colonies of Great Britain. A little more than 100 years later, on July 4, 1776, the United States of America was founded. ${ }^{6}$

The Sea Islands, the focus of this thesis, encompasses a distinctive ecological zone along the Atlantic coastal region from present day Wilmington, North Carolina, into Charleston, South Carolina, through Savannah, Georgia into Jacksonville, Florida. Similar to West Africa's Atlantic coast, this region is characterized by a system of rivers which meander into the Atlantic, forming swamps and marshlands which frequently 
flood, and a warm subtropical climate which proved to be ideal for the cultivation of rice and other cash crops such as indigo and eventually cotton. The Sea Islands climate and geographical features drew the interest of many slaveholders which led to the arrival of three African slaves into the colony with the first White settlers on the South Carolina Sea Islands plantations in 1670. Of Mende origin, they represented the ideal African slaves whose slave labor would intentionally make the South Carolina Sea Islands primarily a rice growing province. During this initial stage, the Royal African Company of England in 1672 working from their fort on Bance Island began taking Africans to the New World. After this method of transporting failed as an operation due to mismanagement, other forts throughout the Gambia were used. For slaveholders, the Gambia was considered the most significant agricultural rice region. Peter Wood has stated that, "No development had greater impact upon the course of South Carolina history than the successful introduction of rice." ${ }^{, 7}$ This recognition began around 1685, when the first rice seed was brought to South Carolina from Madagascar by Captain John Thurber. This seed became known as the fabled "Carolina Gold Rice." Later, Robert Rowan would introduce "Carolina White Rice" that became more popular. ${ }^{8}$

The preference of a new group of African slaves emerged from Angola. The Angolans were designated as field hands because of their massive physiques compared to other African ethnic groups. However, rice cultivation owed success not only to the supposedly superior physique of slave labor, but to the skills most brought with them into the productive process deployed by them on South Carolina plantations. Work on the plantation was gendered to a certain extent. In general, this era designated male slaves as field hands and female slaves as house slaves on the plantation. This system of gendered 
labor is especially evident with the importation of African slaves from the Gambia. They served mainly as house slaves; their presence would be short-lived due to warfare and the disintegration of the Wolof Empire. ${ }^{9}$

The cultivation of rice was dependent on this rising of African slaves throughout this early period. To gain and expand their wealth, planters and traders worked together to enslave Africans from what came to be known as the Windward coast of West Africa, a region where most Africans seemingly specialized in growing rice. The word "seemingly" is used because Wood has stated that while not every slave entering South Carolina had been drawn from an African rice field, and many, perhaps even a great majority had never seen a rice plant, literally hundreds of the slaves were more familiar with the planting, hoeing, processing, and cooking of rice than were the European settlers who purchased them. ${ }^{10}$

Using indigenous West African work techniques including using ones foot to dig a hole in the soil, drop in the rice seed, and then cover the seed with soil, the cultivation of rice was a tedious process which required one to stand in the marshy water with rice hooks while allowing the rice to dry for a day. After this, the rice was tied in sheaves, stacked and transported on boats for shipping to the threshing yard- a place where other African slaves separated the head of the rice from the stalk by hand. Next, the rice went through a process of winnowing or "fanning." This process consisted of using Sweetwater baskets woven by slaves as an African tradition native to Sierra Leone, to separate the grain. After this, the rice was "pounded" to remove the outer husks and inner cuticle. ${ }^{11}$ During the early 1700 's, rice cultivation was to the inland swamps where dikes controlled irrigation. By mid century, planters learned more efficient techniques to 
regulate the tidal floods to irrigate and drain the rice fields. As a result, rice-cultivation moved to tidal swamps that lined coastal waters. However, with the extremely unhealthy living conditions with the cultivation of rice, the death rate of slaves increased. In response to the rising death toll, slaveholders continued to import African slaves from West Africa whose skills in technology and agronomy were used to further develop the rice-growing industry on the Sea Islands. ${ }^{12}$

Furthermore, with the introduction of rice, was an increased importation of African slaves. In 1708 , the slave population exceeded the White population on the Sea Islands. By 1720 , the Black community outnumbered Whites and benefited from a three to one majority in South Carolina. According to Charles Joyner and Jeffrey W. Bolster, it was not until the 1730 's that approximately 25 to 30 African slaves from the CongoAngola region who entered North America were brought to South Carolina. Slaves from Angola contributed to the large Black population on the Sea Islands. In 1737, Samuel Dyssli, a Swiss newcomer to the United States stated, "Carolina looks more like a negro country than like a country settled by white people."13 By 1740 , the slave population of South Carolina had risen dramatically to 39,155 while that of the White population was about 20,000 . A ratio of two to one was reached in the colony for the first time. ${ }^{14}$ This demographic factor certainly influenced the decision of Bantu-speaking slaves to revolt in protest of the conditions on the plantation.

In the morning of Sunday, September 9, 1739, a group of twenty African slaves known as Angolans planned an uprising led by a male African slave named Jemmy. The group met at the Stono River in St. Paul's Parish, no more than twenty minutes away from Charles Town, before trailing through the city to a nearby store that housed artillery. 
The group raided the store and executed the White storekeepers. Their heads were left as a threat to others. They then proceeded to several homes of White families to burn and kill the inhabitants. No more than twenty-five White persons were killed in the uprising. After murdering several families, they took to the streets, marching and encouraging other African slaves who watched from afar, to join the force. After a few minutes, the small group of twenty had increased to more than fifty. As they marched, they were recognized by Lieutenant Governor Bull of South Carolina who hastily retreated from the area by horseback of fear of being killed. After marching ten miles without being confronted, the emboldened group began to celebrate. They beat two drums and shouted "liberty."15

Once they reached the Edisto River, they waited for other African slaves to join the group before crossing in a quest for freedom. However, it was during this waiting period that more than one-hundred planters at a church were alerted about the uprising. When the planters approached, the group of African slaves retaliated by firing two shots igniting the planters to violently respond. The Africans fired as well, though others were unable to load their guns in time. As a result of being caught off guard, fourteen slaves were instantly killed. By the end of the rebellion, thirty slaves were dead. Thirty of the rebels verified that they were forced to join the rebellious group and were allowed to return to work on their designated plantations. All others who escaped were captured and executed. Survivors who tried to escape questioning were shot and beheaded as a warning to others. However, there was one male slave who escaped, living as a fugitive for three years until he was captured and hanged. ${ }^{16}$

Shortly after the Stono Rebellion, the number of African slaves from Angola into 
South Carolina was drastically severed. Fearing future rebellions, slaveholders favored Africans from other regions. They increased the importation of Africans from the Windward Coast in Senegambia. ${ }^{17}$ There were also fears that African slaves were organizing secret meetings to plan another revolt. Many slaveholders became extremely harsh to help control any inclination of revolt. While the treatment of slaves had grown increasingly harsh between 1720 and 1739, after the rising, slaveholders began to reflect on their policies. As a result, the General Assembly passed the Security Act of 1739 requiring all White men to carry firearms on Sundays which was a day many slaves had as free time. Those who did not abide by the new law were fined. A year later, the colonists reconfigured the 1737 Patrol Act which was passed three years later as the Negro Act of 1740 . This act strictly prohibited African slaves from growing their own food, meeting as a group, acquiring monetary rewards, or learning to read. ${ }^{18}$ However, these harsh conditions amplified resistance on the plantation. It wouldn't be long before many slaveholders altered their approach to prevent insurrection by encouraging a more "tolerable" method of slave labor using the task system.

During the initial period of the trade, slaves were usually taken to the Caribbean before being taken into South Carolina. The Middle Period (1749-1787), however, was characterized by Africans being directly imported from Sierra Leone into South Carolina. Richard Oswald who led Bance Island, one of the more established slave trading operations in West Africa between 1750 and 1800, allowed for the importation of preferred African ethnic groups into South Carolina after entering into a business transaction with one of the wealthiest rice planters and slave traders in South Carolina: Henry Laurens. In 1756, he reached an agreement with Laurens which permitted him to 
use his personal ship to help transport African slaves directly from Sierra Leone into Charles Town, South Carolina. ${ }^{19}$ During the third and final period of the trans-Atlantic slave trade we see the beginning of factors which influenced the formation of the Gullah community's history, culture, and identity in slavery and freedom.

\section{Production, White Absenteeism, and Black Cultural Space}

According to the 1860 Census Slave Schedules, in South Carolina alone, there were 482 farm plantations over 1,000 acres. Other farms totaled 1,359 farms between 500-999 acres of land. The most prominent rice, indigo, and cotton plantations on the South Carolina Sea Islands where located in the following counties: Beaufort (Coffin Point Plantation), Charles Town (Snee Farm Plantation and Pinckney Plains), Georgetown (Brookgreen plantation), and Orangeburg (Good Hope plantation). In Beaufort, there were 32,530 slaves and 1,068 slaveholders throughout the county. However, with slaveholders owning more than one plantation throughout the South Carolina Sea Islands, this number is slightly skewed. Beaufort was the second largest slaveholding county next to Charles Town. In Charles Town, there were a total of 37,290 slaves owned by 2,880 slaveholders. In Georgetown, there were 18,109 slaves in the county. Georgetown was ranked among the top 20 largest slaveholding states with Ward as the largest slaveholder. There were 481 slaveholders throughout this county. In Orangeburg, there were 16,583 slaves and 1,093 slaveholders. $^{20}$

The rice plantations are Snee Farm Plantation and Brookgreen Plantation; the indigo plantation is Pinckney Plains; the cotton plantations are Coffin Point Plantation and Good Hope plantation. These plantations are highlighted in conjunction with four 
factors that influenced the unique nature of slavery on the Sea Islands: the size of the plantation, the population of African slaves, the plantation system of production, and the pattern of absentee ownership that helped develop Black cultural that influenced the retention of African cultural traditions such as folktales. In South Carolina, the majority of plantations were disproportionately large compared to smaller plantations in the upland regions of the South. According to Eugene D. Genovese, small plantations contained less than fifty slaves, while, large plantations contained more than fifty slaves. $^{21}$

The two most prominent rice plantations on the South Carolina Sea Islands included Snee Farm Plantation and Brookgreen Plantation. Snee Farm Plantation was located in Mount Pleasant, a suburb in Charles Town on Sullivan's Island. Although the plantation had many owners, the Pinckney family who owned the plantation from 1754 to 1817 is considered. Colonel Charles Pinckney was the owner from 1754 to 1782 . When he died in 1782, his son, Charles Pinckney took ownership of the plantation from 1782 to 1817. Although the Pinckney family owned a total of seven plantations and over 240 slaves, Snee Farm was one of the modest plantations. Snee Farm was a 715 acre, ricegrowing and indigo plantation with a small slave population. In 1787, Pinckney owned 46 slaves on the absentee owner plantation. Archaeological evidence demonstrates that during Charles Pinckney's tenure, the task system was the predominant method of labor employed on Snee Farm Plantation. ${ }^{22}$

Brookgreen Plantation was located on All Saints Parish in Georgetown. Joshua John Ward, known as the most prominent slaveholder in the nation, was the owner. In comparison to other All Saints Parish plantations, Brookgreen was the largest and most 
successful. According to the 1860 Census Slave Schedules, Ward owned a total of 1,121 slaves who produced $4,410,000$ pounds of rice annually. This plantation used the task system to help manage slave labor. Joyner writes, "The labor system under which the slaves of All Saints Parish worked and took justifiable pride in their work output was the task system, in general use on rice plantations during the antebellum period. ${ }^{, 23}$ However, labor on the plantation helped create a paternalistic relationship between the slave and slaveholder. For example, Ward's wife frequently distributed large rations of food to encourage dependence in the slave community. Her plan was successful to a degree since many slaves bragged about life on the plantation. The task system not only promoted a paternalistic relationship between the slave and slaveholder but helped create autonomy through incentives offered for completed tasks. ${ }^{24}$

One of the most prosperous indigo-producing plantations was Pinckney Plains located in Charles Town on upper Ashley River. Pinckney Plains was one of seven plantations owned by Colonel Charles Pinckney and his family. In 1738, Pinckney's second wife, Eliza Lucas Pinckney, the daughter of a slaveholder, began to experiment with various crops such as indigo. By 1747, Eliza had introduced and developed indigo as a staple cash crop on the plantation and throughout the South Carolina Sea Islands. The cultivation of indigo that did not require water harvesting quickly became the second most lucrative cash crop next to rice between 1760 and 1800 . Although data on the number of slaves on the plantation is unavailable, the Pinckney family owned several plantations. Pinckney Plains, a 483-acre plantation was smaller than Snee Farm. It is assumed from the small size of the plantation and the history of the Pinckney slaveholders that this indigo-producing plantation had less than 50 slaves and had 
absentee owners who used the task system. ${ }^{25}$

Most cotton plantations were located in northeast counties of South Carolina; however, there were a few on the Sea Islands as well. Two of these were Coffin Point Plantation and Good Hope plantation. Coffin Point Plantation was located on St. Helena Island. The plantation house was built and owned by Ebenezer Coffin in 1801. That same year, Coffin acquired the plantation from his wife's father who provided him with 1,120 acres and 63 slaves. After his death in 1818, the plantation was left to his son, Thomas A. Coffin. In 1860, Coffin owned 157 slaves. By 1862, there were 260 slaves on Coffin Point Plantation. With over 50 slaves, this plantation was a large and economically prosperous cotton-producing plantation with absentee owners. ${ }^{26}$ Although the method of production on the plantation is unspecified, it is assumed that with the large slave population, the cultivation of cotton, and absentee owners, the task system was used as a method of slave labor.

Good Hope plantation, located in Orangeburg was owned by Joseph Heatly Dulles. This Santee River cotton-producing plantation had a slave population of 175 from 1800 to 1857 . With the recognition of absentee owners, it is assumed that this large plantation relied on the task system. ${ }^{27}$ Gutman states, "It was in communities like the one on the Good Hope plantation that slaves lived most distantly from direct supervision by owning whites. Everyday contact with owners had to be less frequent than on smaller plantations and on farms. ${ }^{28}$ Good Hope plantation retained cohesive kinship and family ties that also existed on the other plantations discussed.

The presence or absence of slaveholders was dependent upon the size of the plantation and the major crop cultivated. The spread of disease also played an important 
role on the plantation. For example, on large rice-producing plantations, the subtropical climate and low-lying swampy marshland yielded an abundance of mosquitoes which contributed to the spread of diseases including malaria, yellow fever, and small pox. Slaveholders fled their plantations on the Sea Islands between April and September, which was known as "malaria season," in hopes of avoiding disease and returned once the season ended. Those who could afford to do so left the Islands completely or took temporary refuge in their homes in nearby Beaufort or Charles Town during the summer. $^{29}$

Many slaveholders only resided on their plantations a few months of the year, as did Reverend Dr. Fuller owner of a large plantation in the Beaufort District, who presided over a church in Baltimore, Maryland. Moreover, Fanny Kemble, the English actress who is most known for her book Journal of a Residence on a Georgian Plantation, 1838-1839 (1863), met her husband, the owner of a sizable rice plantation on St. Simon's Island, while he was on his annual, extended leave in Philadelphia. Other slaveholders favored Boston, Newport and Saratoga Springs. Further, many slaveholders held more than one plantation site in the region, and rotated between them. During these periods formal entertainment included dances and concerts; horse racing and trading and dogfights were also common. Plantation owners also played host to other planters from the region and held hunting and fishing parties during lengthy visits thereby extending the amount of time during which an owner might be absent from his plantation. ${ }^{30}$

All of these patterns of absenteeism enabled slaves to preserve their African heritage. This was especially true of those residing on the larger plantations, where it was possible to go for long periods of time without any contact whatsoever with slaveholders 
and was easier than those who resided on small plantations where the presence of slaveholders would have been more directly felt. Moreover, the system of production also reinforced the retention of African cultural traditions. Generally, large Sea Island plantations used the task system and the smaller plantations used the gang system in deploying slave labor. On the plantation, the task system sharply defined the daily regimen of slave labor responsibilities. Using this system, African slaves were individually responsible for specific tasks depending on physical ability and skill level. Joyner writes that, "there were full-task hands three-quarter-task hands, half-task hands, and quarter-task hands." ${ }^{31}$ The tasks of the field hands included planting, cultivating, and harvesting staple cash crops such as rice, indigo, and cotton. In contrast, the gang system was a more rigorous approach to slave labor. It was mostly used on small cotton plantations. It was a dependent labor system that caused for slaves to rely on one another to complete responsibilities. Although these two labor systems were different, depending on the plantation, the task system resembled the gang system's harsh working conditions. $^{32}$

The role of the overseers and drivers became particularly important in the management of plantations. The overseer was usually a poor White man, although slaveholders in South Carolina and Georgia tended to rely on Black overseers as opposed to White overseers thereby cutting their overall labor costs. For example, throughout the South, Black overseers managed large plantations for both absentee and resident owners for lengthy periods of time. Slave testimonies indicate that Black overseers were viewed as more lenient. Overseers functioned as the authority figure when the slaveholder was absent. They helped maintain order on the plantation by supervising the drivers and the 
slave population. The driver or "rice driver" was often a favored and trusted male slave chosen for his ability to understand various aspects of cultivation whose primary responsibility was making sure the field hands worked effectively. ${ }^{33}$ Ira Berlin writes:

African know-how operated during those first years to place blacks in managerial as well as menial positions and thereby permitted blacks to gain a larger share of the fruits of the new land than whites might otherwise allow. In such circumstances, white domination made itself felt, but both whites and blacks incorporated much of West African culture into their new way of life. ${ }^{34}$

According to Genovese and Joyner, Black drivers were so effective that many were able to manage the plantations themselves. During the Civil War, when many slaveholders fled plantations on the South Carolina Sea Islands, older male slaves with loyal and trustworthy reputations were designated drivers. Although the owner or overseer was responsible for assigning tasks, they still had to consult the Black drivers who directly managed the field hands and made important decisions concerning the cultivation of rice. ${ }^{35}$ Joyner writes, "Once in the field the driver pointed out to each slave the task for the day, which had been determined in consultation with the overseer. It was the driver's responsibility to inspect the completed task and approve the performance before a slave was allowed to go home."36

Whether the designated authority figure served as an overseer or driver, the task system was enforced on absentee owner plantations through long, strenuous work days that were originally against the purpose and benefits of the task system. However, with the absence of slaveholders who established this system of labor on the plantation, the overseer and driver were left to manage or mismanage the plantation. For example, though the task system encouraged a flexible work schedule, this was not always the 
case. Depending on the plantations definition of the task system, slave labor could either last into the night, or end in the evening with allotted free time. Slave testimonies explain how the task system fostered longer work days rather than shorter work days on the South Carolina Sea Islands. John W. Blassingame cited the slave narrative of James L. Bradley, a male slave who was classified as a field hand on the plantations of South Carolina and Arkansas, describes the task system in a letter written in 1835: "I used to work very hard. I was always obliged to be in the field by sunrise, and labored till dark, stopping only at noon long enough to eat dinner. ${ }^{, 37}$ On many plantations, a fourteen-hour work day was typical. ${ }^{38}$

John Andrew Jackson, a former African slave was also interviewed about his experience as a field hand on a plantation in Sumter County in 1893. He stated that on many plantations, slaves weren't fed properly leading to physical weakness and many were severely punished for slowing down. Rosa Barnwell, an African slave in South Carolina writing about her experiences in 1862 stated that, "The hands were obliged to go to work at 4 o'clock in the morning, and if they did not finish their task, had to stay till 11 at night. The overseer was a very cruel man, who applied the lash freely, and at all hours of the day. ${ }^{39}$ Barnwell also provided another account of life as a slave. She describes the life of an old African male slave who stopped working before completing his task due to physical exhaustion. The punishment he received resulted in his death 24 hours later. Jackson's experience as a slave is similar to Barnwell's slave experience. His explained that slaves were driven to work in the fields from morning to night. They were lashed by the overseer's whip to finish their work. Additionally, if the task was completed earlier than expected, many times the work load was increased. Overseers often went against the 
task system established by slaveholders when absent. ${ }^{40}$

Many slaveholders warned their overseers not to overwork the African slaves to encourage a paternalistic relationship on the plantation. Paternalism was promoted to prevent tension or anxiety between the slaveholder and slave. Slaveholders who exercised a paternalistic ideology believed malnourished or physically punished slaves reflected their social status, but this was not the case for all slaveholders. There are many accounts in which the health conditions of slaves were extremely poor compared to slaves on different plantations. Continuous availability of the slaves from the trade meant that malnourished and dead slaves could be replaced. However, many paternalistic slaveholders who sought to discourage animosity used the task system as a compromise between the slaveholder and slave on the plantation. ${ }^{41}$

An anonymous former African slave was interviewed about a particular slaveholder who used the task system stated, "General [Isaac] Stevens is pursuing a very good plan with the negroes who come to him for protection. He makes them all work, which they do cheerfully and readily upon the promise of receiving wages." 42 Not only did many slaveholders try to lessen the amount of work allotted to African slaves, but the amount of whippings received in response to disciplinarian practices such as not completing a task by the end of the day which received the harshest consequence. Although it was advised by many slaveholders that African slaves were not to receive more than fifteen lashings, this was not the case for most South Carolina plantations especially with absentee slaveholders. These personal experiences expose the life of African slaves under the authority of the overseer and/or driver. Blassingame's discussion of slave narratives mentioned newly emancipated Africans who worked as field hands 
and house servants, and were interviewed about life on a Beaufort County plantation in

1861. One former slave stated:

I have invariably been told by the negroes that they were not well fed. The first reason a black man, or woman, or child assigns for deserting his owner is the small quantity and poor quality of food given him; the next reason is the same story about clothing; then comes the complaint of hard usage, hard work, and occasionally of cruelty. The last is rare, in my experience. The most of them speak, it is true, of instances where negroes have been recently shot, but few allude to previous hardships worse than whipping. ${ }^{43}$

With White absenteeism, the task system promoted longer work days on plantations on the South Carolina Sea Islands before the Stono Rebellion. After the revolt, work days shortened and slaveholders on the Sea Islands replaced the gang system with the task system. The task system was used to encourage efficiency in slave labor and discourage resistance and insurrection on the plantation. The task system permitted slaves to complete tasks within a reasonable time to support contentment with life on the plantation. Genovese explains that on a number of rice-producing Sea Islands plantations, normal work days typically did not exceed ten hours, while on other plantations, the work days did not exceed five or six hours. Essentially, for many slaveholders, the task system was an effective method that made accomplishing short-term goals feasible. From the slaveholder's point-of-view, the task system was productive because slaves seemed to work harder to complete daily responsibilities with a work quota. ${ }^{44}$

The task system can be seen as a compromise between the slaveholder and slave. Slaveholders used the task system to make slaves responsible for individual jobs and to increase slave labor that was many times inconsistent on the plantations. Many 
slaveholders, unaware of this system of resistance continued to utilize the task system because finishing tasks meant their plantation was accumulating wealth. While unthreatening to slaveholders, for the slaves, this task system was to their advantage. For example, slaves could complete their tasks without working as effectively as the overseer expected, yet could avoid punishment. Using this work ethic, the goal of many slaves was to complete tasks earlier than expected to gain additional leisure time. Berlin writes, "With little direct supervision from slaveholders, enslaved persons and their black foremen conspired to preserve a large portion of the day for their own use, while meeting their masters' minimum work requirements. ${ }^{, 45}$

Particularly, after the harvest, the work of slaves became lighter. With lighter tasks, the work day typically began before sunrise, ending at three o'clock in the afternoon to avoid the humid subtropical climate. Slaves either worked on Saturday, or had Saturday and Sunday off. It was illegal for slaves to work on Sundays. The plantations that permitted the slaves shorter work days and weekends off indicate the benefits of the task system that offered incentives for completed tasks. This system allowed African slaves to work at their own pace while using individualistic labor methods. When the slaves were not working, they enjoyed recreational activities, drawn particularly from their African heritage. For example, African slaves used their free time to do other household chores, patch clothes, hunt, fish, and tend to tend to gardens that provided them with a certain amount of control over their lives. Although slave men typically hunted and slave women completed domestic chores such as washed clothes, many slaves had farm plots to harvest their own crops and animals not only to supplement their diets but to open their own markets to sell their harvested crops to other 
slaves or slaveholders to make money, perhaps to even save to purchase their freedom or someone else's. ${ }^{46}$ This attainment to leisure time allowed the slaves to have access to the slaveholder's property for their own use throughout the eighteenth century. The task system ultimately stressed individual innovation among the slave community.

Interestingly, one of the wealthiest slaveholders, Charles Pinckney purchased vegetables and poultry from slaves on his plantation in which he confessed that " 25 percent of the rice crop was entering the market through the hands of pilfering slaves." ${ }^{, 47}$ Other slaves enjoyed visiting nearby plantations especially since White absenteeism facilitated such behavior. On larger plantations such as Joshua Ward's 1,000 labor force, it was possible for slaves to go missing for short periods of time and not go noticed. ${ }^{48}$ Due to large plantations with absentee owners that provided the availability of free time, it was easy for many plantations to develop an insulated, autonomous slave community that used innovative tactics to survive plantation life.

Slaves on plantations such as the All Saints Parish plantations who used the task system developed a creolized African American community that creatively adapted to life on the plantation by fusing their African culture with American culture to create the Gullah culture. Evenings and weekends were ideal for practicing African cultural traditions such as basket weaving, singing and dancing, and telling folktales. These tales were orally transmitted in the Gullah language from one generation to the next to teach important life lessons to children as a method of education and socialization. According to Roger Abrahams, these tales are associated with nighttime entertainment on the plantation that helped unite old and young slaves who celebrated life despite the conditions of slavery. ${ }^{49}$ 
Similar to the autonomy inherent in the task system, maritime slavery had its benefits. The role of male slaves involved in maritime labor along the rivers and streams of low-land South Carolina also allowed for a measure of cultural autonomy and the forging of ties outside of specific plantation boundaries. According to Bolster, the slaves obtained from countries such as Senegambia and Sierra Leone were most likely to have had experience in seafaring. Maritime slavery consisted of male slaves who worked as watermen, boatmen, fishermen and pilots. Their occupation was to help transport supplies and products to plantations by waterway transport. However, maritime slaves used the waterways not only for labor, but for leisure especially since maritime slavery linked the slaves to other plantations throughout the state and region. Water transport made it easier to travel to nearby cities that linked the slaves to other plantations throughout the state and region. ${ }^{50}$

Maritime work allowed male slaves to engage in a number of enterprises that were unsupervised by White persons. Moreover, the common ancestral ties, cultural traditions and language spoken by the slaves residing along the coastal waterways of South Carolina and Georgia were reinforced in ways not recognized by Whites. Waterways superseded the political boundaries which separated the two states. And the coastal regions of both states shared patterns of White absenteeism, isolation, and production utilizing slave labor. Water transport facilitated visiting patterns and allowed the slaves to get around the pass system which helped create a large slave community that was bound by numerous ties of kinship, friendship and culture. The flexibility of the task system together with access to water transport allowed many slaves to travel unsupervised throughout the countryside, congregate in the woods, and visit Charles 
Town to carouse, conspire, or worse. Sea Island watermen could travel to neighboring states throughout the Carolina lowland and Virginia tidewater regions, undeniably coming into contact with free Black persons and slaves. This mobility made the White population apprehensive of the role of slaves in maritime activities; mobility meant that information was easily passed, fugitives harbored, insurrections planned; runaways could visit relatives and wives on distant plantations, and pilferage, which slaves saw as compensation for their masters' constant appropriation of their labor, made easier. While most are familiar with the overland routes escaping slaves utilized to obtain their freedom, maritime historians believe that approximately one third of escaping slaves achieved their freedom through the use of in-land coastal waterways. Robert Smalls, a trusted mulatto slave used his seafaring skills to gain freedom. Smalls, a descendent of slaves from Guinea who lived in Beaufort, South Carolina is renowned for impersonating a White captain to navigate the Confederate ship, "Planter" during the Civil War. ${ }^{51}$ Indeed, had White persons ever been able to seal Black access to vessels in those waters, the slave community "would have suffered inordinately." 52 Although the South Carolina Sea Islands was economically efficient with slave labor to ultimately, destroy African presence in America, the largest African community in the United States was created instead: the Gullah community. ${ }^{53}$

During the Final Period (1804-1808), 29,461 Africans were imported from West Africa into South Carolina. By 1808, Africans were imported illegally. South Carolina was the only state that continued to import Africans after it was outlawed by Congress. Slaveholder's believed that slaves from certain areas of Africa were most efficient for plantation labor. Although by 1808 , at least 122,000 Africans from Senegal through 
Angola were imported legally, the influx of slaves from Angola is recognized for significantly contributing to the presence of African heritage on Sea Islands plantations. ${ }^{54}$ Between 1808 and 1860, Sea Island plantations began to drastically change. Due to the antislavery sentiment, plantations decreased in size. In 1860 , there were 69 percent of slaves in units of 20 or more. There were 42 percent of slaves in units of 50 or more. According to Rose, "A closer examination has shown, however, that three-fourths of the slaveholders owned fewer than twenty slaves each, and that only 19.9 per cent owned more than fifty. It is curious to note that even in the heart of the Carolina low country the typical planter was a small planter." ${ }^{55}$ At the close of the institution of slavery, there were 33,339 slaves and free persons on the South Carolina Sea Islands, according to the State Census of South Carolina in 1860 . There were 993 property owners with 883,048 acreage of land both improved and unimproved. However, it was not until the issue of the Emancipation Proclamation in 1865, that the institution of slavery ended as a lucrative business in the United States. ${ }^{56}$

The purpose of this chapter has allowed the reader to see how the taking of slaves, the influx of slaves, the production of slave labor, White absenteeism, and the task system have helped create Black cultural space during which specific aspects of the slave communities African heritage flourished before and after the slave trade was legally prohibited. The subsequent chapter continues the historical discussion of Black cultural space during the antebellum and post-slavery era and its focus on the maintenance of African cultural traditions such as folktales as a method to educate and socialize children on South Carolina Sea Islands plantations. 


\section{CHAPTER IV}

\footnotetext{
${ }^{1}$ Wilbur Cross, Gullah Culture in America (Westport, CT: Praeger, 2008). 2.

${ }^{2}$ Daryl C. Dance, From My People: 400 Years of African-American Folklore (New York, NY: Norton, 2002). 1.

${ }^{3}$ Bernard E. Powers, Jr., "A Founding Father and Gullah Culture: The National Park Service traces the dual plantation heritage at the Charles Pinckney National Historic Site near Charleston, South Carolina," in The Magazine of the National Parks and Conservation Association 72, no. 11-12 (1998): 28; Pollitzer, The Gullah People and Their African Heritage (Athens, GA: University of Georgia Press, 1999). 7-43.

${ }^{4}$ National Park Service, Low Country Gullah Culture Special Resource Study (Atlanta, GA: NPS Southeast Regional Office, 2005). 278; Margaret Washington Creel, "A Peculiar People": Slave Religion and Community-Culture among the Gullah (New York, NY: University Press, 1988). 35-37; William S. Pollitzer, The Gullah People and Their African Heritage (Athens, GA: University of Georgia Press, 1999). 43; Peter Wood, Black Majority: Negroes in Colonial South Carolina from 1670 through the Stono Rebellion (New York, NY: W.W. Norton and Company, 1974). 196.

${ }^{5}$ Wood, Black Majority, 3.

${ }^{6}$ Pollitzer, The Gullah People and Their African Heritage, 28; Wood, Black Majority, 3-6; Willie L. Rose, Rehearsal for Reconstruction: the Port Royal Experiment (Indianapolis, IN: Bobbs-Merrill, 1966). 48-55.

${ }^{7}$ Wood, Black Majority, 35.

${ }^{8}$ David D. Wallace, The History of South Carolina (New York, NY: The American Historical Society, 1935). 81; Ibid., 35-59; Charles Joyner, Down by the Riverside: A South Carolina Slave Community (Urbana, IL: University of Illinois Press, 1984). 14; Jeffrey W. Bolster, Black Jacks: African American Seamen in the Age of Sail (Boston, MA: Harvard University Press, 1997). 64.

${ }^{9}$ Philip D. Curtin, The Atlantic Slave Trade: A Census (Madison, Wisconsin: University of Wisconsin Press, 1969). 103-128; Joseph F. Holloway, Africanisms in American Culture (Bloomington, IN: Indiana University Press, 1991). 4-6.

${ }^{10}$ Wood, Black Majority, 59- 61.

${ }^{11}$ Joyner, Down by the Riverside, 47- 48.

${ }^{12}$ Ira Berlin, "Time, Space, and the Evolution of Afro-American Society on British Mainland North America," The American Historical Review 85, no. 1. (1980): 56-59.

${ }^{13}$ Wood, Black Majority, 132.

${ }^{14}$ Joyner, Down by the Riverside, 14; Bolster, Black Jacks, 64; Berlin, "Time, Space, and the Evolution of Afro-American Society on British Mainland North America," 58; Wood, Black Majority, 132-153.

${ }^{15}$ Ibid., 213-317.

${ }^{16}$ Ibid., 217.

${ }^{17}$ Holloway, Africanisms in American Culture, 7, table 4.

${ }^{18}$ Eugene D. Genovese, Roll Jordan Roll: The World the Slaves Made (New York, NY: Random House, Inc., 1972). 54; Mark Smith, ed. Stono: Documenting and Interpreting a Southern Slave Revolt (Columbia, SC: University of South Carolina Press, 2005). 20; Wood, Black Majority, 103.

${ }^{19}$ Ibid., 78 n.

20 "Historical Census Browser," University of Virginia, Geospatial and Statistical Data Center, 2004, accessed April 21, 2012, http://mapserver.lib.virginia.edu/collections/; Tom Blake, "Beaufort County South Carolina Largest Slaveholders From 1860 Slave Census Schedules and Surname Matches For African Americans on 1870 Census," August 2001, accessed April 21, 2012, http://freepages.genealogy.rootsweb.ancestry.com/ ajac/; Blake, "Charlestown County South Carolina Largest Slaveholders From 1860 Slave Census Schedules and Surname Matches For African Americans on 1870 Census," http://freepages.genealogy.rootsweb.ancestry.com/ ajac/; Blake, "Georgetown County South Carolina Largest Slaveholders From 1860 Slave Census Schedules and Surname Matches For African Americans on 1870 Census," http://freepages.genealogy.rootsweb.ancestry.com/ ajac/; Blake, "Orangeburg County South Carolina Largest Slaveholders From 1860 Slave Census Schedules and Surname Matches For African Americans on 1870 Census," http://freepages.genealogy.rootsweb.ancestry.com/ ajac/.
} 
${ }^{21}$ Genovese, Roll Jordan Roll, 366.

${ }^{22}$ Powers, "A Founding Father and Gullah Culture," 26-29; Daniel C. Littlefield, Rice and Slaves:

Ethnicity and the Slave Trade in Colonial South Carolina (Baton Rouge, LA: Louisiana State University

Press, 1981). 63; Robert W. Blythe, Emily Kleine, and Steven H. Moffson. "Charles Pinckney National

Historic Site: Historic Resource Study," National Park Service (2000): 31; National Park Service, Low

Country Gullah Culture Special Resource, 124.

${ }^{23}$ Joyner, Down by the Riverside, 43.

${ }^{24}$ Ibid., 19-20, table 1 and table 2; Ibid., 43; Ibid., 133.

${ }^{25}$ Eliza Lucas, The Letterbook of Eliza Lucas Pinckney, 1739-1762(Charlestown, SC: The South Carolina Historical Society, 1972). 16; National Park Service, Low Country Gullah Culture Special Resource, 124125; Henry A.M. Smith, "The Baronies of South Carolina," ed. Mabel Louise Webber, The South Carolina historical and genealogical magazine 16, no. 4 (1914): 157-158.

${ }^{26}$ Chlotilde R. Martin, Robert B. Cuthbert, and Stephen G. Hoffius, Northern Money, Southern Land: The Lowcountry Plantation Sketches of Chlotilde R. Martin (Columbia, SC: University of South Carolina Press, 2009). 45; Blake, "Beaufort County South Carolina Largest Slaveholders From 1860 Slave Census Schedules and Surname Matches For African Americans on 1870 Census," August 2001, accessed April 21, 2012, http://freepages.genealogy.rootsweb.ancestry.com/ ajac/.

${ }^{27}$ Herbert G. Gutman, The Black Family in Slavery and Freedom, 1750-1925 (New York, NY: Vintage Books, 1976). 46-52.

${ }^{28}$ Gutman, The Black Family in Slavery and Freedom, 1750-1925, 103.

${ }^{29}$ Wood, Black Majority, 64-73.

${ }^{30}$ Rose, Rehearsal for Reconstruction, 118-120. Frances A. Kemble, Journal of a Residence on a Georgian Plantation in 1838-1839 (Athens, GA: University of Georgia Press, ed. 1984, 1863). 111-182.

${ }^{31}$ Joyner, Down by the Riverside, 44.

${ }^{32}$ Berlin, "Time, Space, and the Evolution of Afro-American Society on British Mainland North America," 66.

${ }^{33}$ Genovese, Roll Jordan Roll, 366.

${ }^{34}$ Berlin, "Time, Space, and the Evolution of Afro-American Society on British Mainland North America," 56.

${ }^{35}$ Genovese, Roll Jordan Roll, 366-367; Joyner, Down by the Riverside, 45- 67.

${ }^{36}$ Ibid., 66.

${ }^{37}$ John W. Blassingame, Slave Testimony: Two Centuries of Letters, Speeches, Interviews, and Autobiographies (Baton Rouge, LA: Louisiana State University Press, 1977). 687.

${ }^{38}$ Genovese, Roll Jordan Roll, 59.

${ }^{39}$ Blassingame, Slave Testimony, 511.

${ }^{40}$ Ibid., 511-698.

${ }^{41}$ Berlin, "Time, Space, and the Evolution of Afro-American Society on British Mainland North America," 61; Joyner, Down by the Riverside, 56.

${ }_{42}$ Blassingame, Slave Testimony, 361.

${ }^{43}$ Ibid., 359.

${ }^{44}$ Berlin, "Time, Space, and the Evolution of Afro-American Society on British Mainland North America,"43-66; Blassingame, Slave Testimony, 567.

${ }^{45}$ Ibid., 66.

${ }^{46}$ Ibid., 43-66.

${ }^{47}$ Genovese, Roll Jordan Roll, 599.

${ }^{48}$ Berlin, "Time, Space, and the Evolution of Afro-American Society on British Mainland North America,"43-66; Genovese, Roll Jordan Roll, 567.

${ }^{49}$ Joyner, Down by the Riverside, 2; Patricia Jones-Jackson, When Roots Die/ Endangered Traditions on the Sea Islands (Athens, GA: University of Georgia Press, 1987). xi-xii; Pollitzer, The Gullah People and Their African Heritage, 95; Roger Abrahams, Afro-American Folktales: Stories From Black Traditions in the New World (New York, NY: Pantheon Books, 1985). 4.

${ }^{50}$ Thomas J. Brown and Kitty Green, Lessons Learned From the Gullah Experience: Powerful Forces in Education African American Youth (Columbia, SC: Brown Publishing, 1999). 2-5; Berlin, "Time, Space, and the Evolution of Afro-American Society on British Mainland North America," 58.

${ }^{51}$ Bolster, Black Jacks, 133-143; Rose, Rehearsal for Reconstruction, 191. 
${ }^{52}$ Ibid., 21.

${ }^{53}$ Pollitzer, The Gullah People and Their African Heritage, 67; Joyner, Down by the Riverside, 132; Berlin, "Time, Space, and the Evolution of Afro-American Society on British Mainland North America,"57-67.

${ }^{54}$ Creel, "A Peculiar People," 35-37; Pollitzer, The Gullah People and Their African Heritage, 43; Wood, Black Majority, 196; Ibid., 278-284; Holloway, Africanisms in American Culture, 6-10; Rose, Rehearsal for Reconstruction, 14-15.

${ }_{55}^{55}$ Ibid., 115-116.

${ }^{56}$ Gutman, The Black Family in Slavery and Freedom, 1750-1925, 44, table 10. 
CHAPTER V

\section{THE FAMILY AND CHILD SOCIALIZATION}

Teach our children our history so that they can gain confidence, selfreliance, and courage. ${ }^{1}$

Chapter four provided a historical analysis highlighting those characteristics of slavery that facilitated the emergence of Black cultural space on plantations and its influence on the retention of African folktales on the South Carolina Sea Islands. This chapter discusses the historical and contemporary parameters of kinship and family to explain the cultural contexts in which African folktales are used to educate and socialize children in the Gullah community.

\section{KINSHIP ON THE PLANTATION}

As explored in chapter four, this research refers back to the Good Hope plantation. This plantation is used to ascertain the character of kinship and community within the Black community on the South Carolina Sea Islands during and after the Civil War. Good Hope plantation, located in Orangeburg, South Carolina along the Santee River, was a large cotton-producing plantation owned by Joseph Heatly Dulles, an absentee owner. Good Hope had a slave population of 175 from 1800 to 1857. Of this population, there were 28 intact nuclear slave families with 154 children who were linked biologically and through marital ties. Within this extended network, the preservation of 
African cultural traditions helped maintain stability within the slave community. ${ }^{2}$

Herbert G. Gutman utilized plantation birth register lists, census slave schedules, and the Negro Cohabitation Certificates to observe and compare domestic arrangements on Good Hope with five other plantations: Cedar Vale in Virginia, Sterling in Louisiana, Bennehan-Cameron in North Carolina, Carlisle in Louisiana, and Henry Watson in Alabama. Although these plantations vary in location, size, and slave labor, they are similar because the slaves shared cultural traditions and created innovative ways to adapt socially and culturally to life on the plantation to construct kinship and family ties. ${ }^{3}$

Specifically, the naming process of slaves is a noticeable indication of kinship and family on the plantation. The cultural practice of naming children was a form of endearment and kinship that included naming slave children after living or deceased relatives and/or designating a pet or nickname. The naming practices on Good Hope detail the names of slave children and the relation of the child to the biologically-related family member with the same name. For example, Clarinda whose slave parents are Affy and On Cargo is named after her maternal grandparent. Additionally, naming a female child after her father was also a cultural practice on the plantation. ${ }^{4}$ Female slaves who took the names of their fathers had feminized names. This is evident on Sterling Plantation in Louisiana where a child was named Josephine, which is a feminized version of Joseph, the name of her father. ${ }^{5}$ Moreover, the use of pet or nicknames which many times replaced the first name was also a form of preserving the memory of family members. Patricia Guthrie explains nicknames as an expression of endearment and indication of strong kinship and family ties. She writes, "These names-given as a sign of recognition by members of the community to which one belongs-also provide basic social 
and personal identity." ${ }^{, 6}$ Through these naming practices, it is evident that kinship networks existed on Good Hope and other plantations to link slave families. ${ }^{7}$

Slaves who transmitted collective experiences generationally served as a primary source of kinship and family cohesion within the slave community on the South Carolina Sea Islands and on other Southern plantations. Marriage on the plantation helped create kinship and family unity on the plantation. Gutman used the 1866 Negro Cohabitation Certificates to acquire kinship and family data on plantations. In nearby Beaufort County, 411 marriages were registered, 58 were married less than 10 years, 23 were married between 10 and 19 years, 19 were married more than twenty years, and eight were married more than 30 years. This data explains that long-standing marriages prior to the Civil War helped sustain stable, nuclear slave families. ${ }^{8}$

On Good Hope plantation, a full birth register contains the names of most slave parents for each child. The name of the slave mother, father, and children indicates a stable slave community on Good Hope where partners were selected based on slaves sold into the plantation, living off of the plantation, or married into the twelve families started between 1800 and 1819 on the plantation. The certificates and register emphasizes that most slave children had two parents who lived in long-standing, settled marriages. ${ }^{9}$

Although Good Hope plantation was not disrupted by frequent sale, interregional migration, or slave transfers that threatened kinship and family structure, Gutman hypothetically describes the slave's response to family separation on the plantation. This separation would have caused the slave family to adapt to domestic arrangements including marital experiences unique to the new plantation. ${ }^{10}$ Gutman writes: 
Remarriage could not fully compensate for the vivid memories and feelings associated with forced separation from a spouse and from other blood kin, but behavior after sale and separation depended partly upon what slaves had experienced and learned in earlier marriages, families, and enlarged kin groups. ${ }^{11}$

Slave communities adapted to life on the plantation to help preserve kinship and

family. According to Gutman:

Slave children born in the 1840 s or the 1850 s grew up in a slave community made up of interrelated but well-defined immediate families. Such ties rooted them in a shared Afro-American past and helped define the identity of particular men, women, and children, allowing slave children to absorb values from parents, grandparents, other adult kin, and adult non-kin. They were not socialized simply by an owner or an overseer; the choices they later made as adults were shaped by socializing experiences rooted within the developing slave community itself. ${ }^{12}$

After 1857, the slaves on Good Hope adapted to plantation life by recreating kinship networks. During and after the Civil War, the last generation of slaves tended to maintain nuclear and resilient families. Gutman's research on Good Hope plantation substantiates the claim that despite the possibility of separation, the slave community that consisted of a biological and extended family that practiced African cultural traditions including folktales to teach children to adapt to and survive life on the plantation while maintaining a cohesive kinship network during and after slavery. It is asserted that since slavery, African cultural traditions including folktales have been preserved and transmitted generationally to help maintain intact kinship ties and promote a sense of communal identity. ${ }^{13}$

On the South Carolina Sea Islands, the slave's primary parental role was to educate and socialize Gullah children. According to William Harrison Pipes, "Parenting 
refers to the person(s) responsible for the nurture and guidance of children through developmental periods into adulthood." ${ }^{14}$ As in any Black community, the family is most important in encouraging children to foster healthy racial identity development by teaching them how to survive in a racist world. Slave parents understood the magnitude of their responsibility to their children, and so did the entire slave community that was secondary to the parent. The plantation was a social environment consisting of the biological and extended family that was responsible for providing mutual support to help children counter the harsh reality of slavery. Throughout the antebellum era, the influx of African slaves, White absenteeism, and the task system contributed to the development of Black cultural space that offered the constant renewal of African cultural traditions including the preservation of African folktales on South Carolina Sea Island plantations. Folktales were transmitted by slaves who were either born in Africa or were the descendants of Africans. These tales that adapted to life on the plantation imparted moral lessons and cultural values to slave children about their African history, culture, and identity. $^{15}$

Although African folktales were told at night on the plantation as an ostensible form of entertainment once slave labor tasks were completed, they were most importantly instructional. These tales were infused with serious messages to educate and socialize slave children to survive on the plantation and to maintain a strong appreciation of their African heritage. African folktales taught children how to act within the slave home and community. Janie Hunter, a native of the South Carolina Sea Islands, explains how her parents passed African folktales as a method to educate and socialize her into a world that did not see her character first, but rather her color. Hunter states, "When I come up, my 
parents sat us down on Sunday afternoon after church and taught us stories, and their life stories-how they came up. Some of my great-grandparents came up in slavery times, and all these stories and folktales that I tell are from way back in the history of slavery times." $" 16$

On Sea Islands plantations, slave parents taught children at an early age to display good manners and respect. According to Eugene Genovese, "For the slaves good manners meant respect for and deference to parents and all adults, black and white." ${ }^{17}$ When a slave child disobeyed an elder, no matter the person's race, both the slave parents and community were responsible for disciplining the child. As a result, African folktales served as a type of "code of conduct." For example, slave children were taught racial etiquette to avoid severe punishment on the plantation. Racial etiquette was a form of manners that taught slave children how to act on the plantation around slaveholders. Particularly, African folktales told on All Saints Parish plantations on the South Carolina Sea Islands stressed the importance of racial etiquette. Other lessons included overcoming obstacles by triumphing over the slaveholder, plotting insurrection, and gaining freedom. The lessons imparted from the tales' content provided various models of conduct for slave children. Moreover, African animal and human tales that included trickster tales that reflected the slaves' inner frustrations provided them with innovative tactics to achieve physical, spiritual, emotional, and/or mental freedom while on the plantation. ${ }^{18}$ These tales "lightened their burden of oppression, promoted group solidarity, provided ways for verbalizing aggression, sustaining hope, building selfesteem, and often represented areas of life largely free from the control of whites." ${ }^{\prime 19}$ African folktales were especially important during an era when reading and 
writing were illegal in Southern states such as South Carolina, both in law and custom. The Slave Code of 1740 legally prevented slaves from writing. In 1834, reading was prohibited out of fear of insurrection. According to Rose, it was believed that by 1862 , a few newly emancipated should have been able to read, but none should have been able to write. ${ }^{20}$ Although these laws and customs were enacted to forbid the literacy of slaves, not all were illiterate. Patricia C. Nichols writes, "Historically denied access to the European literate tradition by laws that forbade African slaves to read and write, and later denied equal access into public education, African-Americans passed along family histories, religious practices, and spiritual beliefs through an oral medium developed in Africa. ${ }^{21}$ Despite the prohibition of reading and writing, slaves used African folktales as a traditional and informal method to educate and socialize slave children.

Slaveholders did not always understand African folktales told in the Gullah language that consists of English and West African words. The Gullah language worked to the slave's advantage because a majority of slaveholders viewed the language as incomprehensible. As a result, this esoteric language was a weapon of defense against slaveholders. Roger Abrahams, Hughes and Bontemps, and John W. Blassingame explain that trickster tales told in a secret language helped the slaves survive life on the plantation. These tales that were partially understood by slaveholders who viewed them as harmless and non-threatening were used to educate and socialize slave children to overcome their statuses as slaves. These trickster characters imitated the bicultural identity embraced by the slaves. ${ }^{22}$ According to Blassingame:

The lessons the slave child learned about conformity were complex and contradictory. Recognizing the overwhelming power of the whites, parents taught children obedience as a means of avoiding pain, suffering, and 
death. At the same time, they did not teach unconditional submission. Instead, children were often taught to fight their masters and overseers to protect their relatives. $^{23}$

African folktales compensated for the laws against teaching persons of African descent to read and write. According to Rose, "Outside the areas where the master class had taken such pains to interfere actively, however, there lay sufficient terrain for the survival of many customs, folkways, and superstitions that bear the distinct imprint of West Africa." 24 Such a regard for literacy is further explained in the shift in social status from slave to contraband.

\section{FROM SLAVE TO CONTRABAND}

Charlotte Forten, a free Black woman from an affluent family in Philadelphia who joined the Port Royal Relief Committee as a volunteer for two years, describes her entrance into the South Carolina Sea Islands:

It was on the afternoon of a warm, murky day late in October that our steamer, the United States, touched the landing at Hilton Head. A motley assemblage had collected on the wharf, -officers, soldiers, and 'contrabands' of every size and hue: black was, however, the prevailing color. The first view of Hilton Head is desolate enough, - a long, low, sandy point, stretching out into the sea, with no visible dwellings on it, except the rows of small white-roofed houses which have lately been built for the freed people. ${ }^{25}$

While traveling by a waterway system from Beaufort to St. Helena Island, Forten observes the South Carolina Sea Islands. She writes, "The houses in the main street, which fronts the 'Bay,' we are large and handsome, built of wood, in the usual Southern style, with spacious piazzas, and surrounded by fine trees. ${ }^{26}$ When she arrives on the 
Island she acknowledges the Black residents and rejoices for their freedom. Forten writes, "Women in bright-colored handkerchiefs, some carrying pails on their heads, were crossing the yard, busy with their morning work; children were playing and tumbling around them. On every face there was a look of serenity and cheerfulness...And I thanked God that I had lived to see this day."27

On November $7^{\text {th }}$ of 1861 , the United States Navy arrived in Port Royal and routed the Confederates and plantation owners out of coastal South Carolina. Slaveholders fled the state abandoning their property including land, slaves, and cotton. After this victory, Beaufort, South Carolina fell into the hands of 12,000 Union Army soldiers. These soldiers were left with a large Black community totaling about 8,000 who were neither a slave nor free. These persons became known as "contrabands of war" after being placed under the authority of the U.S. Department of Treasury since the Emancipation Proclamation had not yet been officially decreed. Furthermore, the federal government, as it existed, was consulted to prepare the "contraband" community for emancipation. The Port Royal Experiment was created in configuration with the development of organizations that included the Educational Commission, National Freedmen's Relief Association and the American Missionary Association (AMA) that recruited northern volunteers to help develop The Port Royal Experiment. These volunteers that consisted of northern missionaries, abolitionists, and schoolteachers who viewed the experiment as an opportunity to show that formerly slaves were fully capable of becoming educated and independent were classified as Gideonites. A year later, The Port Royal Experiment was established on the South Carolina Sea Islands. ${ }^{28}$

In November of 1862, The Port Royal Experiment was developed to "encompass 
political and social changes to equal the transition from slavery to freedom." It had a three-objective agenda. First, these workers wanted to show that free Black persons could become economically prosperous through cotton cultivation. For example, a gang system was replaced with a task system as a method of labor after former slaves resisted. Second, the workers created a system of education. Third, the works focused on getting free Black persons to be property owners. This was used to show that the free Black population could be successful, free persons like White farmers. However, this thesis concentrates on the education objective of The Port Royal Experiment. ${ }^{29}$

The Port Royal Experiment recruited volunteers that included Laura Towne, Ellen Murray and Charlotte Forten. Towne, a Philadelphian native as noted earlier, served as a nurse and schoolteacher on the South Carolina Sea Islands. However, her role as a teacher is most important to this research. Towne believed that the educational objective of The Port Royal Experiment was most beneficial because it succeeded in teaching nearly 2,500 children and adults' reading, writing, and arithmetic. Other lessons focused on vocational skills. Murray, a British woman and close friend to Towne was also a schoolteacher. Both women helped establish the first school for persons of African descent in the United States. ${ }^{30}$

In April 1862 with the help of the Pennsylvania Freedman's Aid Society or Freedmen Association, Towne and Murray received a building and founded Penn School located at Oak Plantation on St. Helena Island in Beaufort, South Carolina. This school focused on teaching free Black persons vocational skills. With the interest in literacy, the school outgrew its location and moved to Brick Baptist Church in September 1882. As the student population continued to increase, once again, the school had to relocate. Penn 
School moved to a 50-acre lot where a pre-built structure was shipped from Pennsylvania to South Carolina. This building became the first official Penn School headquarters. Towne and Murray dedicated forty years of their lives to teaching on the South Carolina Sea Islands. ${ }^{31}$ According to Rose:

Here the first troops were recruited among the late slaves and put to the test of battle; the first extensive schools for slaves got under way and the assault on illiteracy began; abandoned land was confiscated and freemen took precarious title; the wage system received several trials and freedmen experimented with strikes and bargaining; political rallies and local politics first opened up an exciting range of experience. ${ }^{32}$

Forten was also qualified to teach at Penn School. As the first Black teacher hired to teach in Salem, Massachusetts, her prior teaching experience is most valuable to this research. $^{33}$

Although the goals of these teachers were to increase literacy within the Black community on the South Carolina Sea Islands, to their amazement, many of the adults and children were literate. Forten alludes to the literacy that was already present before the teachers and missionaries arrived to develop a method of formal schooling. She describes the life of Don Carlos, a newly emancipated man who was taught to read while a slave. She describes him as "a man of considerable intelligence." ${ }^{34}$ Education that included learning to read and write was a top priority for most Black families on the South Carolina Sea Islands especially since school was only offered for three months of the year. By 1862 , there were more than 1,700 children in the schools of St. Helena, Ladies, and Port Royal Islands combined. While it was known that many Black children learned their letters from White children, others had received secret instruction. Forten writes, "We went into the school, and heard the children read and spell. The teachers tell 
us that they have made great improvement in a very short time, and I noticed with pleasure how bright, how eager to learn many of them seem."35 Although many field hands related the power of reading and writing with both the slaveholder and privileged slaves such as drivers and domestics, all slaves desired an education. ${ }^{36}$

As a schoolteacher, Forten's class consisted mostly of young children who required picture-books and toys. However, for the older students, Forten taught basic literacy and arithmetic that included lessons on the English alphabet to teach the students to read and write. The children were also taught about the stars and moon, the birth of Christ, successful Black Americans, and Negro spirituals such as "Roll, Jordan Roll." Forten described her morning walk to the school that was on the Oak Plantation located in a Baptist Church, "My walk to school, of about a mile, was part of the way through a road lined with trees,- on one side stately pines, on the other noble live-oaks, hung with moss and canopied with vines. ${ }^{37}$ However, her description of her first day teaching a large class with very young and older students on the Sea Islands is not as pleasant. Forten writes, "Had my first regular teaching experience, and to you and you only friend beloved, will I acknowledge that it was not a very pleasant one. ${ }^{38}$ She mentioned that there were moments in which she was overwhelmed by the large school, yet she was inspired. Forten acknowledged the resiliency of her young students who she described as well-mannered and invested in their education especially since they studied between completing chores and working in the fields. Although the children were well-behaved and passionate about their education, their attention span was short which made it difficult to teach since her class consisted of younger and older students. Forten writes, "It is hard to keep them quiet and interested while I am hearing the larger ones. They are 
too young even for the alphabet, it seems to me. ${ }^{39}$

Notwithstanding the challenge, Forten remained motivated to teach the children about their ancestors including the heroic life of Toussaint Louverture that provided an example of heroism to encourage positive racial identity development. ${ }^{40}$ These school lessons resemble the function of African folktales that also educated and socialized children. According to Rose, "Most teachers agreed that on the lower levels of learning, involving in those days primarily rote memory of letters and numbers the children acquitted themselves exceptionally well. A long heritage of oral communication of folk customs, songs, and stories perhaps prepared the children to shine in these exercises." By December 31,1863 , the social status of former slaves changed from "contraband" to "emancipated." However, the post-antebellum era posed the same problem that established the institution of slavery: racial inequality. According to Idus A. Newby:

Between 1895 and 1968 the black Carolinian received few objective assurances of his equality with the white Carolinian. When he cast around for evidence of his equality, the black Carolinian found the consequences of discrimination. By the standards his society had taught him, he and his fellow blacks were poorer than whites, less educated, less cultures, less polished in social grace, less accomplished in every professional and vocational endeavor, less the masters of their fate, in a word, less civilized. $^{42}$

Due to institutional racism, the stability of the Black family remained especially vital to kinship and family connections in the contemporary Gullah community.

\section{KINSHIP AND COMMUNITY IN CONTEMPORARY PERSPECTIVES}

Patricia Guthrie offers a description of kinship and family structure on St. Helena Island plantation communities through the concept of catching sense that has helped to 
insulate Gullah-speaking persons who continue to practice their African heritage by transmitting African cultural traditions such as folktales to educate and socialize children on the Sea Islands since slavery. The Gullah family and community consists of a biological and extended kinship network that goes beyond a nuclear family comprised of a husband and wife to include fosterage and the role of grandparents in the rearing of children. ${ }^{43}$

Guthrie supports her discussion on kinship and family in the Gullah community by studying the compositions of 56 households totaling 207 persons on Fremont Plantation. Although the basic unit of a household consists of a married couple, she distinguished four different types of household compositions. The first type includes 20 households with one generation not only containing a husband and wife but widows and single women. The second type includes 23 households with two generations containing the husband and his wife and children, a widow with children, separated/ divorced wives with children, and single women with children. The third type includes nine households with three generations containing the husband-wife-children-grandchildren, husbandwife-grandchildren, widow-foster child-foster grandchildren, and widow-grandchildrenwidow's brother. The fourth type includes four households with four generations containing of the husband-wife-grandchildren-wife's mother, widow-childrengrandchildren with cohabitating partners and great grandchildren, and a single woman with children, grandchildren, and her mother's brother. Furthermore, each household unit consists of a household headship and household members who are designated certain responsibilities. Household headship includes persons who are married, widows, separated/ divorced, or single. In a marriage, both the husband and wife are appointed 
gendered responsibilities. For example, while the husband manages joint financial obligations, the wife manages the receipt and offering of produce. The household head governs members who are biologically related, or a part of an extended kinship network as household members that could include direct descendants and foster children, and resident and resident non-plantation members. ${ }^{44}$

On the Sea Islands, religion is a fusion of African spirituality and a Christian belief system that teaches children realistic and consecrated lessons to help them reach full personhood which indicates a level of maturity reached. Although praise house buildings no longer exist, its function subsists to resolve community issues including disputes, theft, and disrespect within household membership. Guthrie describes catching sense as a psychosocial and cross-cultural process that helps children, ages two to twelve years old, determine the community in which they belong. In the slave community, catching sense was a socio-religious ritual practiced by slave parents and community members to help guide children to adulthood. This unique survival strategy taught slave children to value a "collective memory" that reinforced kinship and family cohesiveness and unity within the slave community and after the Civil War when newly emancipated heads of households were granted land ownership. ${ }^{45}$

On January 16, 1865, General William Tecumseh Sherman proposed Special Field Order No. 15 that would designate the settlement of free Black persons on the Sea Islands. This proposal guaranteed unoccupied or abandoned land tracts and loaned army mules to newly emancipated persons on the Sea Islands. Although this order was an attempt to authorize the forty acres and a mule as a form of restitution for slavery, it was annulled the following year. As a result, most of the land was returned to former 
slaveholders. Despite this cancelation, many newly emancipated persons managed to keep their land, purchase or claim other areas of abandoned land. However, since many Black land owners did not officially record their heir deeds, their property was threatened by White developers. Although a majority of the free Black population experienced accelerated land loss, catching sense was a valuable advantage in maintaining family stability especially with the transmission of African cultural traditions such as folktales in the household. ${ }^{46}$ Guthrie writes:

Catching sense gave people their guiding principles, their knowledge of how to interact with one another. The process ended when the person belonged, when he or she left childhood and entered adulthood. Children became true members of their community when their social world and their social relationships expanded to include the public as well as the domestic domain. ${ }^{47}$

According to Guthrie, household composition includes members who caught sense on a plantation or did not catch sense, and members who belong to different churches and/or small praise houses important to the process of catching sense. Aspects of their African cultural traditions that include folktales function to educate and socialize children about their African heritage and the world in which they live within the household and community are still present. As a result, catching sense and kinship remains central to the lives of Gullah-speaking persons within the household and community. It has also helped the Gullah family and community to teach children valuable life lessons about transitioning into adulthood. It is possible that African folktales were used to help children learn moral lessons and cultural values. It is asserted that coupled with catching sense, African folktales not only continue to serve as a method to educate and socialize Gullah children due to timeless relevancy of the tales' content, 
but these tales help support kinship ties within the Gullah community. ${ }^{48}$

On the Sea Islands, it is commonly believed by Gullah-speaking persons that in comparison to children reared in urban areas, children reared in rural areas are more respectable and obedient. However, throughout the Gullah community, children are taught to respect a communal identity that values kinship bonds. As a result, the Gullah community on the South Carolina Sea Islands has managed to preserve and maintain strong kinship and family patterns within two social systems: the home and community. The Gullah family and community consists not only of the biological family, but an extended family that also included fictive kin who are responsible for teaching children moral lessons and cultural values such as modeling responsibility and respect for self and elders. $^{49}$

According to Andrew Billingsley, there are five ways in which the Black family socializes children. First, the community has always served as an extension of the family and parents that serves as a trusted elder to help prepare and guide children. Second, the community members are role models to admire. Third, the community encourages children to fight for what they believe in. Fourth, the community takes interest in the children, making sure they are educated and socialized to lead productive lives. And finally, the community serves as the primary teacher of children. ${ }^{50}$ Billingsley writes about the resiliency of Black families in America:

Strong families are those which seem to be guided in their patterns of interaction among members and with the outside world by a definite set of values or philosophy, with an accompanying pattern of behavior consistent with those values, and a certain degree of independence and control of the forces affecting the lives of their members. ${ }^{51}$ 
With the replacement of institutional slavery with institutional racism, the education and socialization of children is extremely vital to Black communities such as Gullah-speaking persons. Black parents are entitled to preparing their children to develop a bicultural identity that functions effectively in both a Black and White milieu. A bicultural identity supports the concept of "double consciousness" portrayed by the trickster character in African folktales. As bicultural, these tales teach children strategies on how to act, refrain from making negative decisions, and interact in inter-racial social settings. According to King, it is the parent's responsibility to teach children "how to forge a balance between social courtesies to whites and their own self-esteem. ${ }^{, 52}$ Black parents are encouraged to teach their children to develop a bicultural identity by educating and socializing their children on how to behave and respond in racially oppressive social contexts. Marguerite A. Wright examines the socialization of Black children at an early age. She writes:

According to psychologist Erik Erickson, children's primary psychosocial task at this time of life, around ages five and six, is to develop 'industry,' that is, self-confidence, self-discipline, and competence. They are supposed to learn the formal skills of life, how to play by the rules, and be a team member. If they do not learn these life skills, they become subject to feelings of inadequacy and inferiority. ${ }^{53}$

Furthermore, Wright describes the role of Black parents in regard to their children:

Black parents have a special responsibility to their children, who, because of their skin color, are likely to face challenges that many other children cannot even imagine. With love and nurturance from their families and support from society, black children have as good a chance to grow up feeling positive about themselves and their prospects as any other children. ${ }^{54}$ 
In the United States, Black parents are challenged to prepare their children to develop a healthy racial identity to counter institutional racism. Seven concepts explain Black children's understanding of their racial identity and its implications in a racist America. The first concept is social knowledge or social awareness. According to Harriette Pipes McAdoo, the interactions between Black children and others construct social knowledge or the understanding of one's social environment. Children develop social awareness by adapting to their environment. The second concept is socialization. Socialization is the process by which parents teach children how to navigate in various social systems. The third concept, racial socialization, is more precise in definition. It is the process by which parents shape their children's understanding of race. The fourth concept is identity. Identity or self-concept is the understanding of self that characterizes human behavior. The fifth concept is racial identity, which is the mental and emotional understanding of self. The sixth concept is racial awareness. Racial awareness is the acknowledgement of cultural differences and similarities. Children read the stage of racial identity when they learn to recognize and understand racial categories. The seventh concept, racial empowerment, emulates resilient traits of a group that overcomes major obstacles such as racism and oppression. These concepts describe the development of racial identity. In the African American community, racial socialization prepares children to survive successfully or unsuccessfully in the United States. ${ }^{55}$

Black parents use traditional cultural traditions such as African folktales to impart moral lessons and cultural values that racially socialize children to overcome adversity and appreciate their African heritage. African folktales prepare children to foster a bicultural identity in which they can navigate successfully in Black and White milieus. 
These folktales help raise Black children in the Gullah community. Joyner writes:

The old talk and the old tales, the old prayers and the old personal expressiveness are more than just quaint cultural artifacts. They have provided the islanders with a sense of continuity with generations gone before, a precious lifeline to courageous ancestors who survived slavery and endured generations of poverty. That heritage is a source of strength that has enables them to cope with the hail and upheaval of life. As we drift further and further out upon the sea of modernization, that heritage may be as crucial to our sanity and survival as to theirs. The Sea Islanders and their folk culture have something precious to offer us if we do not destroy them first. ${ }^{56}$

This chapter has examined kinship patterns on the plantation, the status change from slave to contraband, and kinship and community patterns in contemporary perspectives from the antebellum to post-slavery era that details the conditions that the missionaries, abolitionists, and Union army found at the time of 1862 and Charlotte Forten's daily account as a schoolteacher on the South Carolina Sea Islands to explain the cultural contexts in which African folktales are used to educate and socialize children in the Gullah community. An analysis of Good Hope plantation has been explored to provide the background of the kinship system that the slaves created during the antebellum era. An analysis of contemporary kinship has been studied using Guthrie's observation of family and community on St. Helena Island. This allows for an observation of the environment that existed through which children were socialized and also provided a cultural context through which the transmission of African derived folktales took place. The next chapter presents a literary and cultural analysis of ten African folktales comprised of moral lessons and cultural values that were used and adapted on the plantation and in the contemporary Gullah community on the South Carolina Sea Islands. 


\section{CHAPTER V}

${ }^{1}$ Marian Wright Edelman, "A Portrait of Inequality," in Black Families, ed., Harriette Pipes McAdoo, Fourth Ed. (Thousand Oaks, CA: Sage Publications, Inc., 2007). 325.

${ }^{2}$ Herbert G. Gutman, The Black Family in Slavery and Freedom, 1750-1925 (New York, NY: Vintage Books, 1976). 46-95; Gutman, The Black Family in Slavery and Freedom, 1750-1925, 95.

${ }^{3}$ Ibid., 133-135.

${ }^{4}$ Ibid., 94-95, table 13.

${ }^{5}$ Ibid.,119, table 15.

${ }^{6}$ Patricia Guthrie, Catching Sense: African American Communities on a South Carolina Sea Island (Westport, CT: Bergin \& Garvey, 1996). 46-87.

${ }^{7}$ Guthrie, Catching Sense, 46-87.

${ }^{8}$ Negro Cohabitation Certificates was a registration of slave marriages that reported long-standing marriages on Southern plantations such as Good Hope.; Gutman, The Black Family in Slavery and Freedom, 1750-1925, 14-16, table 3.

${ }^{9}$ Ibid., 86-123; Ibid., 45-53, table 11-12.

${ }^{10}$ Ibid., 145-152.

${ }^{11}$ Ibid., 152.

${ }^{12}$ Ibid., 87.

${ }^{13}$ Ibid., 88-95; Ibid., 204-223.

${ }^{14}$ William Harrison Pipes, “Old Time Religion: Benches Can't Say 'Amen,"” in Black Families, ed., Harriette Pipes McAdoo, Fourth Ed. (Thousand Oaks, CA: Sage Publications, Inc., 2007). 120.

${ }^{15}$ Mary A. Twining \& Keith E. Baird, "An Examination of African Retention in the Folk Culture of the South Carolina and Georgia Sea Islands" in Sea Island Roots: African Presence in the Carolinas and Georgia, Mary A. Twining \& Keith E. Baird (Trenton, NJ: Africa World Press, 1990). viii; Idus A. Newby, Black Carolinians: A History of Blacks in South Carolina From 1895 to 1968 (Columbia, SC: University of South Carolina Press, 1973). 140; Eugene D. Genovese, Roll Jordan Roll: The World the Slaves Made (New York, NY: Random House, Inc., 1972). 522; John Hope Franklin, "African American Families: A Historical Note," in Black Families, ed., Harriette Pipes McAdoo, Fourth Ed. (Thousand Oaks, CA: Sage Publications, Inc., 2007). 4; Wilma King, Stolen Childhood: Slave Youth in Nineteenth-Century America (Bloomington, IN: Indiana University Press, 1995). 71; Hazel Arnett Ervin, The Handbook of African American Literature (Gainesville, FL: University Press of Florida, 2004). 63.

${ }^{16}$ Roger Abrahams, ed. Afro-American Folktales: Stories From Black Traditions in the New World (New York, NY: Pantheon Books, 1985). 18; King, Stolen Childhood, 98; Guy Carawan and Candie Carawan, Ain't You Got a Right to the Tree of Life: The People of Johns Island, South Carolina, their Faces, their Words, and their Songs (Athens, GA: University of Georgia Press, 1989). 215.

${ }^{17}$ Genovese, Roll Jordan Roll, 511.

${ }^{18}$ Steven Barboza, The African American Book of Values: Classic Moral Stories (New York, NY: Doubleday, 1998).794; Willie Lee Rose, Rehearsal for Reconstruction: the Port Royal Experiment (Indianapolis, IN: Bobbs-Merrill, 1964). 134. Charles Joyner, Shared Traditions: Southern History and Folk Culture (Urbana, IL: University of Illinois Press, 1999). 192-193; Rose, Rehearsal for Reconstruction, 136; John W. Blassingame, The Slave Community: Plantation Life in the Antebellum South, Revised and Enlarged Ed. (New York, NY: Oxford University Press Inc., 1972). 188; Charles Joyner, Down by the Riverside: A South Carolina Slave Community (Urbana, IL: University of Illinois Press, 1984). 194.

${ }^{19}$ Blassingame, The Slave Community, 105.

${ }^{20}$ Rose, Rehearsal for Reconstruction, 86.

${ }^{21}$ Patricia C. Nichols, "Storytelling in Carolina: Continuities and Contrasts," Anthropology \& Education Quarterly 20, no. 3 (1989): 234.

${ }_{22}$ Abrahams, Afro-American Folktales, 9; Langston Hughes and Arna Bontemps, ed. The Book of Negro Folklore (New York, NY: Dodd and Meade, 1958). viii; Blassingame, The Slave Community, 127; William S. Pollitzer, The Gullah People and Their African Heritage (Athens, GA: University of Georgia Press, 1999). 162. Joyner, Down by the Riverside, 175; Blassingame, The Slave Community, 127; W. E. B. Du Bois, The Souls of Black Folk (The Souls of Black Folk (Rockville, MD: Arc Manor, 1964). 12-17; Martha Sims and Martine Stephens, Living Folklore: An Introduction to the Study of People and Their Traditions (Logan, UT: Utah State University Press, 2005). 153; Blassingame, The Slave Community, 186; Joyner, Shared Traditions, 16; Rose, Rehearsal for Reconstruction, 136. 
${ }^{23}$ Blassingame, The Slave Community, 188.

${ }^{24}$ Rose, Rehearsal for Reconstruction, 96.

${ }^{25}$ Charlotte Forten, "Life on the Sea Islands, Part I." Atlantic Monthly XIII (1864): 587.

${ }^{26}$ Forten, "Life on the Sea Islands, Part I.," 587.

${ }^{27}$ Ibid., 588.

${ }^{28}$ Rose, Rehearsal for Reconstruction, 15; Guthrie, Catching Sense, 2-3.

${ }^{29}$ Rose, Rehearsal for Reconstruction, 38; Ibid., 82-83.

${ }^{30}$ Guthrie, Catching Sense, 3-5.

${ }^{31}$ Rose, Rehearsal for Reconstruction, 203; National Park Service, Low Country Gullah Culture Special Resource Study (Atlanta, GA: NPS Southeast Regional Office, 2005). 126; Wilbur Cross, Gullah Culture in America (Westport, CT: Praeger, 2008). 32; Guthrie, Catching Sense, 4.

${ }^{32}$ Ibid., xviii

${ }^{33}$ Cross, Gullah Culture in America, 35.

${ }^{34}$ Charlotte Forten, diary entry, Wednesday, October 29, 1862, in The Journals of Charlotte Forten Grimke, 391.

${ }^{35}$ Forten, diary entry, Sunday, April 5, 1863, in The Journals of Charlotte Forten Grimke, ed., Brenda Stevenson (New York, NY: Oxford University Press, 1988, 470.

${ }^{36}$ Rose, Rehearsal for Reconstruction, 87; Ibid., 230-234; Ibid., 29-33; Rose, Rehearsal for Reconstruction, 87.

${ }^{37}$ Forten, "Life on the Sea Islands, Part I.," 592.

${ }^{38}$ Ibid., diary entry, Wednesday, November 5, 1862, in The Journals of Charlotte Forten Grimke, 394.

${ }^{39}$ Ibid., Wednesday, November 5 1862, in The Journals of Charlotte Forten Grimke, 394; Ibid., Rehearsal for Reconstruction, 161; Ibid., diary entry, The Journals of Charlotte Forten Grimke, 398-424; Ibid., diary entry, Monday December 15 1862, 419; Rose, Rehearsal for Reconstruction, 231; Forten, diary entry, Friday, October 31 1862, in The Journals of Charlotte Forten Grimke, 392; Ibid., Wednesday, November 5 1862 , in The Journals of Charlotte Forten Grimke, 394.

${ }^{40}$ Ibid., diary entry, Thursday, November 13, 1862, 397-398.

${ }^{41}$ Rose, Rehearsal for Reconstruction, 230.

${ }^{42}$ Newby, Black Carolinians, 21.

${ }^{43}$ Guthrie, Catching Sense, 6; Ibid., 59.

${ }^{44}$ Ibid., 49-55, table 1.

${ }^{45}$ Ira Berlin, "Time, Space, and the Evolution of Afro-American Society on British Mainland North America," The American Historical Review 85, no. 1. (1980): 66; Patricia Guthrie, Catching Sense: African American Communities on a South Carolina Sea Island (Westport, CT: Bergin \& Garvey, 1996). 3. ${ }^{46}$ Ibid., 92-108; Barboza, The African American Book of Values, 557; Ibid., 506; K Sue. Jewell, Survival of the African American Family: The Institutional Impact of U.S. Social Policy (Westport, CT: Praeger Publishers, 2003). 20; Guthrie, Catching Sense, 9; Ibid., 31-38; Ibid., 106-107; Rose, Rehearsal for Reconstruction, 285.

${ }^{47}$ Patricia Guthrie, "Catching Sense" and the Meaning of Belonging on a South Carolina Sea Island, ed. Shelia Walker, In African Roots/American Cultures (Lanham, MD: Rowman and Littlefield, 2001). 282. ${ }^{48}$ Guthrie, Catching Sense, 61-108.

${ }^{49}$ Ibid., 57; Pollitzer, The Gullah People and Their African Heritage, 8-9; National Park Service, Low Country Gullah Culture Special Resource Study, 88; Guthrie, Catching Sense, 58.

${ }^{50}$ Andrew Billingsley, Black Families in White America, Climbing Jacob's Ladder: The enduring legacy of African American families (New York, NY: Simon \& Schuster, 1992). 97-99.

${ }^{51}$ Billingsley, Black Families in White America, Climbing Jacob's Ladder, 97-98.

${ }^{52}$ King, Stolen Childhood, 71.

${ }^{53}$ Marguerite A. Wright, I'm Chocolate You're Vanilla: Raising Healthy Black and Biracial Children in a Race-Conscious World (San Francisco, CA: Jossey-Bass Publishers, 1998). 123.

${ }^{54}$ Wright, I'm Chocolate You're Vanilla, 144-145.

${ }^{55}$ Jan Carter-Black, "Teaching cultural competence: An innovative strategy grounded in the universality of storytelling as depicted in African and African American storytelling traditions," Journal of Social Work Education 43, no. 1 (2007): 36; Harriette Pipes McAdoo, "The Village Talks: Racial Socialization of Our Children," in Black Children: Social, Educational, and Parental Environments, ed. Harriette Pipes McAdoo (Thousand Oaks, CA: Sage Publications Inc., 2002). 50-88; Black, "Teaching cultural 
competence: An innovative strategy grounded in the universality of storytelling as depicted in African and African American storytelling traditions," 36; James P. Comer and Alvin F. Poussaint, Black Child Care: How to bring up a healthy black child in American: a guide to emotional and psychological development (New York, NY: Simon \& Schuster, 1975). 119; Harriette Pipes McAdoo, ed. Black Children: Social, Educational, and Parental Environments (Thousand Oaks, CA: Sage Publications Inc., 2002). 133; McAdoo, Black Children, xii; Jewell, Survival of the African American Family, 167; Ibid., 276; Lawrence W. Levine, Black Culture and Black Consciousness: Afro-American Folk Thought from Slavery to Freedom (New York, NY: Oxford University Press, 1977). 153; McAdoo, Black Children, 48; Black, "Teaching cultural competence," 34; King, Stolen Childhood, 72; Carolyn Bennett Murray and Jelani Mandara, "Racial Identity Development in African American Children: Cognitive and Experiential Antecedents," in Black Children: Social, Educational, and Parental Environments, ed. Harriette Pipes McAdoo (Thousand Oaks, CA: Sage Publications Inc., 2002). 85.

${ }^{56}$ Joyner, Shared Traditions, 281. 


\section{CHAPTER VI}

\section{LITERARY AND CULTURAL ANALYSIS}

On the slave plantation, African folktales were "painfully realistic stories which taught the art of surviving and even triumphing in the face of a hostile environment."

This chapter is a literary and cultural analysis of African folktales that were used and adapted on the South Carolina Sea Islands of the United States. This chapter thoroughly addresses the second research question that focus on the function, moral lessons, and cultural values present in the tales' content to educate and socialize children on the plantation, as well as Gullah children today:

1. What moral lessons and cultural values were conveyed by African folktales directed at children during the time of slavery and in contemporary society among the Gullah community on the South Carolina Sea Islands?

This research explores ten African folktales. Of the ten tales examined, six are animal tales and four are human tales. The animal tales explored are: "De Eagle An Eh Chillun," "Buh Turkey Buzzard and the Rain," "Origin of the Races," "You Never Know What Trouble Is Until It Finds You," "Chanticleer and the Barnyard Rooster," "Buh Lion and Buh Goat," "Buh Raccoon and Buh Possum." The human tales explored are: "Den to De Fiah," "John Saves Old Master's Children," and the "The People Could Fly." These tales are a reflection of the historical and contemporary living conditions experienced by 
Black communities such as the Gullah community.

Julius Lester explains that African folktales reflect individual and collective stories about ourselves and ancestors. These fables are cautionary, escape, humorous, and/or trickster animal and human tales that teach children a variety of lessons pertaining to: parent $\&$ child responsibilities, racial identity \& White privilege, human interactions, and building character traits such as courage, bravery, and resiliency. According to Steven Barboza, African folktales are examples of "the strengths, versatility, and resiliency of blacks-historic figures and relative unknowns." Moral lessons and cultural values are imparted from the content of these tales to help reconstruct the Black community that has been negatively impacted by slavery. ${ }^{2}$

African folktales were orally transmitted and subsequently preserved on the plantation as a central tool in maintaining a strong African heritage. ${ }^{3}$ Animal and human tales imparted lessons that taught slave children the importance of racial etiquette, responsibility, and attaining freedom amongst other cultural values. On the plantation, the characters in the African folktales revealed an authentic portrait of slave life on the plantation. ${ }^{4}$ Today, African folktales continue to serve as a creative way to preserve African heritage under oppressive living conditions. The moral lessons and cultural values of these folktales function to educate and socialize Black children to prepare them to rise above obstacles such as racism and oppression. Wade W. Nobles writes:

Given that African American children must become adults during a period in which racism, discrimination, and oppression will change disguises and not simply go away, the family parent-child relationship must center on the creation and maintenance of three senses: the sense of history, the sense of family, and the sense of the ultimate supreme power (God). ${ }^{5}$ 
This literary and cultural analysis is divided in a way that emphasizes the various lessons taught to children. The first of these lessons is parent and child responsibilities that teach children the benefits of working hard and refraining from preventable mistakes.

\section{PARENT AND CHILD RESPONSIBILITIES}

Three animal tales are highlighted: "De Eagle An Eh Chillun," "Buh Turkey Buzzard and the Rain," and "Buh Raccoon and Buh Possum." "De Eagle An Eh Chillun," teaches children to listen and to respect their parents. This tale provides content that focuses on the role of parents and their responsibility with an emphasis on the role of the Black father. It is the parent's responsibility to model the success that they want their children to achieve by being fearless of their potential. Yet, it is also the child's responsibility to exercise their full potential as prepared by the parent. The main focus is on the role of the parent and the prosperous work ethic modeled by parents.

"Buh Turkey Buzzard and the Rain" is a cautionary, escape, and humorous tale that teaches children to value lessons learned from parents. However, this tale teaches important lessons from the child's point of view. This tale provides content that focuses on the role of the child who must remember the wisdom and knowledge imparted from the parents. Although modeled by parents, it is the child's responsibility to lead a productive life. There are two goals that propel this tale. First, this tale teaches children to refrain from making mistakes. Second, this tale teaches children to learn from mistakes rather than perpetuate social problems such as disregarding racially oppressive behavior. As a result, the child must prove their resiliency by refraining from bad habits in order to meet goals and aspirations. This tale teaches that irresponsibility does not accomplish 
goals.

"Buh Raccoon and Buh Possum" is a cautionary and humorous trickster tale. This tale teaches children the repercussions of disobeying parents' guidance and perpetuating preventable mistakes. This tale teaches the importance of preserving integrity or dignity in the midst of oppression. Rather than covering issues with laughter and humor, this tale teaches children to adopt values such as courage, bravery, and resiliency modeled by parents to handle issues such as bullying. The dogs symbolize the oppressors, and Buh Possum's actions symbolize survival humor. Additionally, this tale teaches children to take ownership of responsibilities. Buh Possum is the character who represents the child whose irresponsibility and cowardice leads to his surrender to oppression. The lesson imparts that children must learn two lessons. They must learn to refrain from making careless mistakes, and they must learn to learn from their mistakes rather than perpetuate social problems to lead productive lives.

These three tales share similar thematic lessons that include the role of responsibility. Barboza writes, "Being responsible means being accountable, answerable, dependable, liable, or reliable. It means fulfilling one's obligation or duty. " ${ }^{, 6}$ This means that it is the responsibility of parents to educate and socialize their children to lead productive lives. Leading a productive life means being prepared to work diligently as responsible adults. The importance of developing a positive work ethic and honoring responsibility are moral lessons and cultural values acknowledged by African Americans in the United States. Barboza explains that, "African Americans have always had a strong work ethic. Hard work, in fact, is one of our most enduring legacies, in spite of its wretched origins in slavery."7 


\section{De Eagle An Eh Chillun}

In this animal tale, Buh Eagle is a wise eagle bird who supports and protects his two children. He does everything he can as a good parent, including providing his children food, shelter, and guidance to grow and become mighty birds like him. Rather than smother his children by keeping them sheltered to grow lazy, Buh Eagle encourages his children to reach their full potential. He teaches his children how to foster a good work ethic. He teaches them how to fly and be the best that they can. Once they learn to fly properly, Buh Eagle flies out from under his children's wings, allowing them to soar on their own because they have learned all that the wise Eagle could teach. They must now support and protect one another as Buh Eagle did for them.

Moreover, the family is the primary social system that educates and socializes children. This tale emphasizes the imperative role of Black parents because family is the primary social system that educates and socializes children. This tale also teaches that each parent must have a distinctive role in the lives of their children. This tale teaches a lesson that the father is just as important as the mother in the children's education and socialization since it uses the father as the main character. For example, Buh Eagle served as a positive role model for his children who taught the importance of working hard. He represented all of the characteristics of a strong and wise bird, which allowed his children to reach the same status. The father works to support and protect the children. This tale encourages the notion that slave families were nuclear or representative of American ideals of family because they had adapted to life in the United States. Traditional American values teach that the father's role is to work as the "breadwinner," while the mother rears the children as a homemaker. The value of the American dream is imbedded 
in American culture, and has been since slavery. As a result, this tale teaches the importance of maintaining a nuclear family but emphasizes that the father and mother both contribute to the education and socialization of children. According to Patricia Guthrie, both male and female household heads are responsible in the rearing of children. ${ }^{8}$ Both parents teach the child how to beat the racist stereotype that all Black people are lazy and irresponsible.

This animal tale emphasizes the role of the father historically and contemporarily. Slave parents prepared the child to exercise a productive work ethic, including teaching lessons about responsibility and accountability with production on the plantation. Wilma King writes about the role of slave parents:

Enslaved parents had an unusually heavy responsibility, for they not only had to survive but they also had to ensure that their children survived under conditions that were tantamount to perpetual war between slaveholders fighting to control their chattel while the bond servants were struggling to free themselves from the control of others. The African heritage was an important factor in how enslaved mothers and fathers guided their children through the strife.

This animal tale teaches the importance of the education and socialization of children to reach their full potential by working hard and appreciating responsibility which is a valuable gift shared between the parent and child within the Black family. This animal tale is extremely important in teaching parents how to prepare their children to be productive as adults. The father did not shelter his children by keeping them in the house and not working. He taught his children how to work by showing them how to work. Despite the impact of slavery on the slave family, the role of the slave father remained honored because he was the epitome of courage and compassion. ${ }^{10}$ According to Harold 


\section{Courlander:}

People ought to take notice of Buh Eagle and do as he does. When your children get big enough to work, make them work. Don't let them sit around the house doing nothing and expecting their fathers and mother to find food and clothes for them. If you do, your children are going to make you ashamed, and they will turn out very trifling. They will keep you dead-poor, too. Do the same as Buh Eagle. Mind your children well when they're little; and soon as they're big enough to work, make them work. ${ }^{11}$

On the plantation, this animal tale was important because it emphasized the specific role of slave parents. Slaves did not own their children- the slaveholder did, which further supported the paternalistic relationship that existed between the slave and the slaveholder on various plantations. Many male slaves viewed the slaveholder paternalistically which was emasculating and negatively impacted their roles as father's.

Other male slaves rejected paternalism on the plantation and remained the authority figure within the slave family. For the male slaves who rejected paternalism on the plantation, the status of the slave father was apparent. Slave parents taught children a multitude of lessons including the value of fostering a productive work ethic. On the plantation, work was first priority. It was important that at an early age, slave children were educated and socialized to work hard to avoid physical discipline such as whipping by slaveholders. This value in a productive work ethic also implied the rewards of incentives such as leisure time after tasks were completed, or better yet, emancipation.

"De Eagle An Eh Chillun" teaches that no matter the laws of slavery, the role of the slave father was important in exerting aspects of masculinity, power, and authority. John D. Smith referenced W. E. B. Du Bois who believed that because the slave husband did not have any power in the slave family, the slave home lacked strong leadership. 
Scholars such as Du Bois described the slave father or husband more like a guest in his own home who did not own any form of respect or responsibility. ${ }^{12}$ Despite this claim, the role of the slave father was integral to the identity development of slave children. V. Lynn Kennedy describes several slave families with father figures who helped educate and socialize slave children. Kennedy explains that "In a society intent on denying enslaved men any fatherhood rights that might challenge the claims of the white patriarchy, each assertion of paternal influence and family connections challenged the identity assigned to black men by antebellum society." ${ }^{13}$ This understanding of the Black father is in juxtaposition with the lessons imparted from the tales' content that focuses on the positive role the father in the Black family beginning with a true understanding of his role on the plantation on the South Carolina Sea Islands.

This tale provides for contemporary Gullah children, an example that demonstrates their ancestor's achievements. Barboza writes about the function of such tales in the education and socialization of children, "We can teach children to grow with their obligations and duties by giving them charge over small matters at first and slowly increasing their responsibilities. An important lesson might involve holding them accountable for tasks or work they agree to take on or are assigned." ${ }^{14}$ This tale teaches the importance of valuing responsibility by learning from their parents to work hard and reap the benefits of accomplished goals.

\section{Buh Turkey Buzzard and the Rain}

In this animal tale, Buh Turkey Buzzard lacks common sense that would enable him to get out of a bad situation. Such an account is evident when the rain is very heavy 
and lasts a long time. Although it is pouring rain, Buh Turkey Buzzard rests on a fence while trying to hide his head. He feels at his worst and promises himself that as soon as the rain ceases, he will build a house to protect himself from future rain fall. However, as soon as the rain comes to an end and the sun shines, he forgets about his promise to himself. Rather than keep his promise and build a house to shelter himself from future rains, he enjoys the current beautiful weather believing that since the rain stopped, it will never return. He convinces himself that he does not need to build the house anymore because the sun will always shine to make him feel happy and content. Essentially, this animal tale teaches lessons about carelessness and laziness, and the importance of preparing for the future. Rather than prepare for rain or unexpected obstacles, Buh Turkey Buzzard is content with his present condition because he is careless. He does not have a plan to escape such a depressing circumstance in the future. The experience of the rain should have encouraged Buh Turkey Buzzard to build a house, however, he was content is his current position. The rain is a constant reminder that people do not have control over the unexpected. This cautionary, escape, and humorous tale describes Buh Turkey Buzzard as a foolish bird whose laziness prevents him from living a stable life. Courlander writes, "A careless man is just like Buh Turkey Buzzard."15

On the plantation, this tale taught slave children lessons about responsibility, commitment, and determination. This tale teaches that life is unpredictable. This tale is told to prevent children from making careless mistakes. It teaches children the value of honoring a productive work ethic despite the belief that all Black persons are lazy. For example, irresponsibility is the refusal to recognize important duties. Refusing to own up to mistakes is also an act of irresponsibility. Buh Turkey Buzzard symbolizes a person 
who makes poor decisions. Persons like Buh Turkey Buzzard believe that making a choice is not always an option. ${ }^{16}$ This belief is detrimental if one refuses against a constructive choice. Barboza writes:

The older we grow, the more responsibilities we learn to manage. Some people, however, simply refuse to grow with new responsibilities. No matter how light their load, they struggle against being held accountable. Rejecting responsibility or refusing to explore your full potential to manage it is a mark of immaturity. So is not living up to the consequences of your actions. ${ }^{17}$

This tale teaches the importance of learning from mistakes and making positive decisions which is highly valued in the Gullah community. Buh Turkey Buzzard poor choices make him an example of what not to do. His life is a testament to how life can go wrong if one continues to make bad decisions. Buh Turkey Buzzard was unable to get out of his negative situation because he was not motivated to live a better life. As a result, he is a slave mentally because he cannot see beyond his current situation. For example, this tale teaches a lesson about many slaves who, after receiving freedom papers, decided to remain on the plantation because of contentment with the daily routine of slave labor. Many slaves were conditioned to accept life on the plantation rather than plot for freedom. Rather than interpret slavery as a debilitating experience by remembering the atrocities of his life as a slave, he remains a dependent slave out of pure comfort, than gain any form of freedom. Buh Turkey Buzzard is similar to minstrel figures such as the "Sambo" character in American literature. Buh Turkey Buzzard is described as "docile but irresponsible, loyal but lazy, humble but chronically given to lying and stealing.",

Today, this tale teaches that no matter one's circumstances learn from the past to prevent future mishaps. This tale is used to motivate children to make positive decisions. 
The moral lessons and cultural values imparted from this tell teaches Gullah children to appreciate their African history, culture, and identity. This tale provides Black children examples that if they are responsible, committed, and self-disciplined that they will achieve.

\section{Buh Raccoon and Buh Possum}

In this animal tale, Buh Raccoon questions Buh Possum on why he doubles over and doesn't fight back when the dogs attack him. Buh Possum responds with a foolish smile that his actions are in response to being tickled which causes him to forget to fight. Buh Raccoon does not understand Buh Possum's reasoning. The lesson in this animal tale is, "The cowardly man has all kinds of lies to tell to excuse himself."19 This tale teaches that rather than make excuses for cowardly motives and behavior, one should confront fears.

One interpretation of Buh Possum's actions is that he uses trickery in a negative way to mask his pain. Buh Possum feels that the only way to counter being tormented by the pack of dogs is by ignoring them. Rather than dealing with his issues, he makes excuses, denying that he is a victim. As a trickster, Buh Possum masks his fear and pain with laughter so that he does not have to deal with the reality of his circumstance. The fact that he laughs away his problems in the midst of misery supports the racial stereotype that Black persons are accustomed to dealing with racial oppression and have become desensitized to its negative impact.

On the plantation, the vicious dogs could symbolize plantation patrolmen such as overseers and drivers. Buh Possum symbolizes the positive and negative trickster traits of 
a slave, whereas Buh Raccoon symbolizes a resilient slave. According to Lawrence Levine, many slaves were mostly interested in learning lessons that helped them to avoid the victimization experienced by oppressors. ${ }^{20}$ This tale teaches children to learn from Buh Possum's foolish ways.

This cautionary tales teaches two lessons. First, the realistic feature of the dogs teaches a lesson about life on the plantation. Slaveholders used dogs such as hounds to instill fear and prevent insurrection. Many African slaves who ran away feared their encounter with hounds. Eugene Genovese writes, "Some slaveholders kept their own 'nigger dogs'- especially fierce hounds trained to track down runaways-but many more enlisted those belonging to poor whites who earned a living as professional slave catchers." These dogs were feared more than the slaveholders because, "They bit, tore, mutilated and if not pulled off in time, killed their prey." However, slaves who presumed to plot insurrection, used trickster techniques to disengage the dogs. ${ }^{21}$ Second, this tale teaches lessons to children about the advantages and disadvantages of laughter to overcome obstacles. The use of laughter to suppress issues is classified as survival humor that is used to guide persons through difficult situations. ${ }^{22}$ On the plantation, survival humor was a trickster motive used to conceal problems. According to Barboza:

Ironically, African American humor traces its origins to terrible times: to slavery, when blacks had precious little to laugh about. But after toiling in the fields or in the big house, they returned to the slave quarters and, among themselves, mocked the master and mistress. Slaves masked their intelligence, feigning ignorance so the master would dismiss them as harmless fools. $^{23}$

This animal tale emphasizes that the use of survival humor can be positive or negative. Levine, Ralph Ellison, and Constance Rourke explain humor in the Black 
community as a positive method in dealing with problems. Survival humor was used on the plantation as a source of control to help oppressed persons maintain a sense of control over their lives by placing frustration at the center of a joke to counteract hopelessness. Many slaves used laughter to create the illusion of combating obstacles as a form of manipulation that helped them understand their anger. ${ }^{24}$ Levine provides a description of humor similar to the way Buh Possum utilizes it:

We have already observed this element at work in the slave trickster tales which induced laughter through a sudden reversal of roles or fortunes. However temporarily, the venerated were vanquished or at least made to look foolish by the lowly. Reversal of roles remained one of the chief mechanisms of black laughter long after slavery, not only one of the chief mechanisms of Black laughter long after slavery, not only in the trickster tales which continues to be popular but in the entire body of jokes which the freedmen and their descendants told one another. ${ }^{25}$

Buh Possum uses humor as a weapon to manipulate his oppressed status, and it is effective to a degree. According to Genovese, oppressed persons who use survival humor to deal with issues makes them dangerous not only to the oppressors, but to themselves. ${ }^{26}$

Yet, the use of humor to hide issues can be debilitating, especially since it is many times linked with minstrelsy. Humor operates to mask feelings of shame. Rather than dealing with internal issues, humor covers these issues up which could contribute to even more problems. Buh Possum, who uses humor to get out of his situation, makes him a different type of trickster: a minstrel character that is not an authentic depiction of the Black experience. According to Levine, Ellison and Sterling Brown, in European American folklore, southern humorists used laughter as a form of entertainment to introduce an exploited and stereotypical portrait of the Black American who became a vacuous, happy-go-lucky, Sambo image. Both Ellison and Brown describe minstrelsy as 
a form of entertainment for White persons, but not for Black persons who would rather confront their issues rather than smile at them. ${ }^{27}$ Constance Rourke writes:

Minstrelsy was of course white masquerade; and the double use of the mask seemed to create a profound satisfaction for American audience, as if the sheer accomplished artifice aroused an instinctive response among them. The mask might be worn as an inheritance or for amusement or as a front against the world in any of these impersonations, concealing a childish and unformed countenance: but it was part of a highly conscious self-projection. ${ }^{28}$

Although Stanley Edgar Hyman believes that "the smart man playing dumb" during "conflict situations" is a primary feature in the Black community, Ellison attacks this claim by stating that the use of humor during difficult situations is an American feature. ${ }^{29}$ Nevertheless, whether humor has a positive or negative function, "Humor is what you wish in your secret heart were not funny, but it is, and you must laugh. Humor is your own unconscious therapy."30

Today, "Buh Raccoon and Buh Possum" exemplifies what not to do in the midst of struggle. It warns children to refrain from making negative choices to avoid negative consequences. It is used to help the child critically think of ways Buh Possum could have reacted differently to the pack of dogs. With this tale, children learn strategies to counter injustices. With the replacement of the institution of slavery with the institution of racism, the dogs metaphorically represent oppressors that could include social issues such as bullying. For many children, being bullied is their first encounter with oppression. Bullying victimizes children who are perceived as powerless or weak. Bullying creates low self-esteem and a lack of confidence which are characteristics fostered by Buh Possum. The moral lessons and cultural values imparted teach that it is the responsibility 
of the oppressed to create solutions to solve injustices such as racial oppression. It is important that the Black child does not identity as a coward, but as a courageous person who can overcome adversity.

\section{RACIAL IDENTITY \& WHITE PRIVILEGE}

In addition to a concern with parental roles and responsibility, racial identity and White privilege are important to the development of Black children. The human tale, "Origin of the Races" and the animal tale, "You Never Know What Trouble Is Until It Finds You" are explored as having the same function with different content. "Origin of the Races" is a cautionary tale that is much different from the other animal and human tales examined. This tale teaches children about race and racial identity within a historical and contemporary context. The construction of race as biological rather than cultural helped justify the institution of slavery that was supported by Anglo-Saxon or White persons. Such an understanding of race helped develop institutional racism in the United States. "You Never Know What Trouble Is Until It Finds You" is a cautionary trickster tale that imparts several lessons with the most important lesson focusing on the impact of White privilege that contributes to racial disparity for Black persons in America.

\section{Origin of the Races}

Uncle Remus is a male slave who shares a tale about race with a little White boy. The child notices that Uncle Remus' palms are White like his own. This discovery mystifies the child, who asks Uncle Remus to explain his color or race. Uncle Remus responds with an explanation that is unwritten history. His tale begins a long time ago 
when the human race was Black. This was a time when everyone got along and was united until a special pond was discovered. According to Uncle Remus, this special pond had the magical power to turn one's skin from Black to White. Many Black persons went to the pond to dip their bodies in to become White. Soon, the pond was overcrowded with Black persons and not everyone could get the full benefits of the pond. While many became White, others became Mulatto (one-half White and one-half Black) by dipping in parts of their bodies. Uncle Remus illustrates that persons, who arrived to the pond late, were only able to dip their hair in the water to straighten it; they became Chinese. The palms of Uncle Remus's hands are only White because he arrived late to the pond (could serve as a symbol of "colored people's time" or CPT, and the repercussions of it). Uncle Remus believes that racial groups such as persons of Chinese, Native American, and Mulatto descent were in the same racial category because of their similar complexion and hair texture. This tale featuring a magical pond was a way for Uncle Remus to describe the evolution of race to the White child.

Although Uncle Remus teaches that the first human was Black, he also teaches a lesson about the inherited privilege of White skin. As a result, this human tale is cautionary. This tale teaches that Uncle Remus wanted to change his Black skin to White even if it meant only dipping his palms into the pond. With White palms, Uncle Remus believes that he has gained an aspect of White privilege. This lesson illustrates how race is politically and psychologically understood by both White and Black persons in America. ${ }^{31}$ Uncle Remus teaches that only persons who are White or look White can succeed in America. This tale teaches the danger of trying to assimilate into European American culture. The danger is becoming a representation of Uncle Remus, a type of 
minstrel caricature who is not an authentic representation of the Black experience.

Joel Chandler Harris originally created Uncle Remus as an "authentic" representation of a Black person, but others subscribed different meanings to the character. According to Hugh T. Keenan, Harris presumed to accurately portray the dialect and demeanor of the character Uncle Remus in his first collection. He believed that Uncle Remus described as smiling, loyal male slave, challenged minstrelsy. However, this character intentionally supports the racial stereotype that slaves were always dedicated to the life of the slaveholder. This depiction makes Uncle Remus a type of minstrel figure who would rather "grin at trouble" than solve his problems logically. This description of Uncle Remus represents a trait of survival humor that existed in Black face minstrelsy which used persons of African descent as a medium of comedy. ${ }^{32}$ Anthony Manna writes, "By playing it smart, Remus resembles the black minstrel showman who, in a grotesque reversal of reality, darkens his face and dresses the part to preserve the stereotype of black inferiority and white superiority.",33

According to Brown, Harris was a southern author who supported slavery through his stereotypical description of African Americans. Since all Black persons used the pond to become White, this tale could be interpreted as supporting Americanization. Manna writes about the repercussions of Uncle Remus's character whose silence toward slavery strips him of his integrity and credibility. ${ }^{34}$ This tale is cautionary because Harris directly supported the institution of slavery. Harris's position makes this human tale cautionary.

With the magical pond, Black persons are able to change their physical appearance to gain social privileges based on race. Black persons who rush to the pond to change their race are interpreted as embodying self-hatred. The description of an 
overcrowded pond alludes to its tremendous importance. It suggests that the White race is viewed as desirous and the Black race is not. This internalization of self-hatred is debilitating to racial identity development. The consequence of the magical pond is that it only changes skin color. It can be assumed that the person only undergoes a physical transformation which could prove problematic. Moreover, there are repercussions for Black persons who do not reach the pond which is an indicator of CPT. The main consequence is that they remain Black and oppressed. However, for Black persons who reach the pond and undergo physical transformation, there is a high chance that most will reject their African history, culture, and identity to assimilate into European American culture. Despite this result, according to Uncle Remus all desire to access the pond to completely transform their physical appearance.

Today, this tale continues to impart the same lessons, but in a different social context. The magical pond symbolizes different tactics used to develop lighter skin to gain social advantages unavailable to persons with darker skin. It teaches that White skin is powerful and Black skin is powerless. The use of this magical pond describes the detestation of Black skin, and the admiration of White skin. This tale teaches a lesson about the Color Complex which is a product of racial oppression. The Color Complex is present in racial division in Black communities based on skin complexion. Modern technology that has the ability to change physical appearance takes the place of the magical pond that Uncle Remus describes. The lessons imparted from the tales' content remains important today because institutional racism is perpetuated with colorism in the Black community. The moral lessons and cultural values imparted educate and socialize Gullah children to understand the historical and contemporary implications of race in 
America.

You Never Know What Trouble Is Until It Finds You

Bruh Rabbit and Bruh Gator are at odds with one another. Bruh Gator constantly boasts about his life of luxury in the marsh land. He brags that his children live in the river which is why they have such a great education. Bruh Rabbit responds to Bruh Gator that it must be nice to not see "Trouble." When Bruh Gator hears about this "Trouble," he becomes interested and asks questions. In disbelief that Bruh Gator never experienced "Trouble," tricky Bruh Rabbit devises a plan to finally stop Bruh Gator from bragging about his life under water. Bruh Rabbit recommends that he introduce Bruh Gator to "Trouble" the following day. They both agree to the meeting. The next day, Bruh Gator gets dressed for his meeting with Bruh Rabbit. As he heads out the door, his wife and children ask him about his travels. He tells them that he is going to meet "Trouble." His wife and children want to go with him. Although apprehensive, Bruh Gator permits them to travel. They leave their quiet home in the marshland to meet Bruh Rabbit and the infamous "Trouble." Once they reach land, they look for Bruh Rabbit in the tall thicket of the sweet grass but he is nowhere to be found. Finally they become tired and take a nap. As they sleep, Bruh Rabbit is nearby, watching them while smoking his pipe low in the grass. As he watches the family all content with their "Trouble"-free lives, Bruh Rabbit knocks the coal from his pipe into the grass, causing a fire that wakes Bruh Gator and his family. Afraid but curious, they admire what seems to be "Trouble," but soon, the fire spreads through the grass, burning the alligator's bare White skin. Watching from afar on a stump, Bruh Rabbit laughs hysterically at their ignorance, yelling to Bruh Gator to stay 
in the marshland if he never wants to experience "Trouble" again. Bruh Gator and his family sprint while crying to their home in the marshland to cool their scorched bodies that are no longer White, but Black and rough-looking. Bruh Gator threatens Bruh Rabbit to stay away from the marshland, or he will get what he came for. As a result of this incident, it is no wonder that all Alligators have a horny hide, and all Rabbits are afraid of Alligators and the marshland.

This cautionary trickster tale teaches many lessons, with the main lesson focusing on race and class privilege. Although Bruh Rabbit's color is never mentioned in any of the African animal tales, he symbolizes an oppressed person who is tainted by racism. Bruh Rabbit is a Black because he lives on land where unexpected problems surface. "Trouble" represents a type obstacle such as racism. Bruh Gator and his family symbolize the oppressor and the oppressor's family because they are described as buckras, a West African term meaning "White people." This tale illustrates that an alligator's natural habitat is in water but the alligator can still survive to a degree on land. This difference in habitat implies that White persons are entitled to certain privileges unavailable to others. However, Bruh Gator is not completely unaffected by racial stratification and the imbalance of power based on race because he eventually meets "Trouble." This tale teaches that even though Bruh Gator or White persons live a life of racial privilege, that White persons are also negatively impacted. Due to their interaction, Bruh Gator is taught what it is like to Black in America.

On the plantation, this tale imparted several lessons that emanate from Bruh Rabbit's duping of Bruh Gator. Bruh Rabbit's habitat on land could represent the plantation since Bruh Gator is taken into a field. Bruh Gator's water habitat could 
represent the plantation house where the slaveholder resided. However, it is not until Bruh Gator is exposed to issues that result on land outside of his natural habitat that he learns a lesson that further differentiates Bruh Rabbit's living circumstances from his own. According to Houston Baker, Jr., "In 'Why Brer Gator's Hide Is So Horny,'” the protagonist conceals his feelings about Brer Gator in order to trick the larger animal into a painful situation, one which alters the gator's perspective as well as his appearance." ${ }^{35}$ Interestingly, the title of this version of the tale alludes to the implications of being a Black person. To be a Black person means to have experienced some form of trouble or difficult social condition. According to Priscilla Jaquith, "Alligator learns that those who go looking for trouble will probably find it." 36

By the end of the tale, Bruh Gator also teaches Bruh Rabbit a lesson. The last sentence of this tale teaches Gullah children about what it means to be a Black person in America. This tale teaches children that racism affects the oppressed as well as the oppressor which explains how Bruh Gator's hide got so Black and rough, or "horny" as the tale describes race. This tale teaches about the competitive relationship between Bruh Gator and Bruh Rabbit. It teaches that the Rabbit or Black person will always reap the disadvantages because of racial oppression that could lead to fear and anxiety. According to Genovese, many slaves were fearful of the slaveholder as well as other White men. ${ }^{37}$

Today, "You Never Know What Trouble Is Until It Finds You" teaches Gullah children the historical and contemporary implications of Blackness in America. It teaches children how White privilege creates economically disparate communities. According to John W. Roberts, since slavery, the race and class disparity that exists because of White privilege has created the perceptions of intra-group privilege based on 
social standing within the Black community. ${ }^{38}$ This tale is an example of oppression which fuels systemic poverty, a class issue that further creates racially disparate communities. It teaches Gullah children to resist racism by exposing its effect on privileged persons who might not understand how their advantages are creating disadvantages for others. This tale encourages Gullah children to challenge racism in creative ways in order to survive; this means that Gullah children learn to "play the system" using the trickster motives that Rabbit is so inclined to use. The moral lessons and cultural values imparted teach Gullah children how to survive in a racist America.

\section{HUMAN INTERACTIONS}

The animal tale "Chanticleer and the Barnyard Rooster" and the human tale "Den To De Fiah" are explored as reflecting intra-racial and interracial human interactions. "Chanticleer and the Barnyard Rooster" is a cautionary trickster tale that imparts lessons about paternalism and friendship. This tale teaches children to develop healthy friendships. "Den To De Fiah" is a cautionary and escape trickster tale that teaches two lessons about human interaction that focus on paternalism and loyalty. This tale teaches children to develop healthy friendships.

\section{Chanticleer and the Barnyard Rooster}

Buh Chanticleer is the most beautiful bird. He is also the most confident, courageous as the leader of the other birds, and has the strongest morning crow. Buh Chanticleer is the best bird on the plantation farm which angers, Yellow Rooster who is a violent gang member. To test Buh Chanticleer's vigor, Yellow Rooster starts a fight, but 
Buh Chanticleer runs him right off the plantation farm. Afterwards, every time he notices Buh Chanticleer coming near, he ran. Yellow Rooster had grown afraid of Buh Chanticleer, but his fear would soon come to an end. As a trickster, Yellow Rooster decides that he was afraid and timid for far too long. Yellow Rooster devises a plan to get even with Buh Chanticleer. He spies on Buh Chanticleer as he practices his morning routine. Yellow Rooster goes to the spot where Buh Chanticleer crows, practicing his morning routine. It is soon that he perfects Buh Chanticleer's crow. He is now ready to show the other birds, which rooster has the best crow.

Buh Chanticleer discovers Yellow Rooster's plan. This frustrates Buh Chanticleer who wants the imposter banished from the plantation farm. Trickster, Buh Chanticleer thinks of ways to throw out Yellow Rooster. A family member gives Buh Chanticleer the idea to call Buh Fox, an animal known as the most vicious trickster of them all, to destroy Yellow Rooster. Buh Chanticleer gives Buh Fox the details about the competition and where to find Yellow Rooster. It is no time before Yellow Rooster is eaten by Buh Fox. But there is just one thing; Buh Fox is still hungry and eats Buh Chanticleer. According to Courlander, the moral lesson of the tale is, "When you want someone to do you a service, call on your friend. Don't trust your enemy to do it." ${ }^{39}$

This cautionary trickster tale was used to impart lessons about human interactions within the slave community, and the slave-slaveholder relationship on the plantation. This tale focuses on the unsuccessful Buh Chanticleer whose trickster motives backfire. Charles Joyner explains that like Buh Chanticleer, many tricksters are unsuccessful and become victims. ${ }^{40}$ Buh Chanticleer's negative choice leads not only to Yellow Rooster's death, but his own. Buh Chanticleer represents the most efficient slaves such as the slave 
driver on the plantation. His followers represent the slave community. Yellow Rooster symbolizes a slave who is jealous of the "drivers" status on the plantation. It is assumed that Buh Fox is a slaveholder because he is not a rooster.

Today, "Chanticleer and the Barnyard Rooster" teaches children the danger of jealously, negative competition, violence, and revenge. This teaches children the consequences of Buh Chanticleer's negative actions. Buh Chanticleer was eaten by an untrustworthy animal: Buh Fox. Barboza explains the importance of teaching children at an early age to distinguish between rewarding and harmful friendships. ${ }^{41}$ The moral lessons and cultural values imparted teach children to be careful when seeking and receiving advice, but most importantly, it teaches children the importance of developing positive human interactions.

\section{Den To De Fiah}

Uncle Jack is a male slave who fights for respect by refusing his tasks on the Sipsey plantation. Uncle Jack is the only slave who has not been caught and whipped by Master Sipsey. This is bothersome to Master Sipsey who wants to discipline Uncle Jack for his refusal. Master Sipsey calls on Jim, a faithful male slave, to help him catch Uncle Jack. As Master Sipsey expects, Jim provides him with Uncle Jack's daily routine. Jim explains that every night he and Uncle Jack sit under a big Oak tree where Jim plays the banjo and sings for Uncle Jack who dances to the music. Jim states that he will help Master Sipsey catch Uncle Jack by building a fire and singing a coded song as a symbol that Uncle Jack is present. Master Sispey and Jim agree to initiate the plan.

That night, Jim sings and plays his Banjo as Uncle Jack dances near the fire. This 
is Master Sipsey signal to attach. When Master Sipsey jumps from behind the tree to catch Uncle Jack, an unaware Uncle Jack throws Master Sipsey into the fire. Master Sipsey survived the fire, but it taught him a lesson about trying to discipline Uncle Jack. Afterwards, Master Sipsey stopped trying to whip Uncle Jack. This is exactly what Uncle Jack wanted.

On the plantation, this cautionary and escape trickster tale describes three trickster characters: Uncle Jack, Jim, and Master Sipsey. Uncle Jack is not a typical "Uncle" character or minstrel caricature. Instead, Uncle Jack is a realistic portrait of a male slave who fights against paternalism and demands respect on the plantation. Genovese describes rebellious slaves who Uncle Jack represented:

There were the individualists who wanted to be left alone, but who gave no trouble when allowed to work in their own way. A master might, if he could without disrupting general discipline, look the other way. But if he could not or would not, then he would have a rough and rebellious man or woman on his hands. These slaves provided a defiant individuality that strengthened the other slave' ability to resist the master as an allcommanding pure will. But they were not likely to be of much help in building a spirit of community solidarity in the quarters, for their power derived precisely from being loners. ${ }^{42}$

Uncle Jack is contrasted with Jim, another male slave who reflects a minstrel caricature as loyal and accepting of paternalism on the plantation. However, the historical use of the name, Jim also references minstrelsy. In the 1830s, Thomas Darthmouth Rice or "Daddy Rice," a White man born in New York made a living by being the first to rub burnt cork on his face while singing and dancing to stereotypically portray a smiling, handicapped Black man during a minstrel routine entitled "the Jim Crow." The name Jim Crow is believed to identify the name of the crippled Black man he portrayed or his 
owner living in Kentucky or Ohio. According to Ellison, African Americans understood the minstrel figure as a complete rejection of their identity not only by White persons, but also African Americans. For example, the presence of Nigger Jim as a minstrel figure was an embarrassment for many Black persons. ${ }^{43} \mathrm{Jim}$ is a degrading character who secretly agrees to help trickster, Master Sipsey catch and punish Uncle Jack. As a result, it would seem that the stereotypical status of the word "Uncle" would best fit Jim, rather than Uncle Jack.

It is assumed that this human tale was not told in close proximity to the slaveholders on the plantation because of its realistic features. This tale identifies a number of key features including the name of the slaveholder, the residential status of the slaveholder, the names of the slaves, the use of the task system, and the presence of leisure time after tasks are completed. These realistic aspects of the tale teach children a realistic portrait of life for slaves. It also presents two characters, Uncle Jack and Jim who view slavery differently. This tale is important in deconstructing the stereotype that all slaves were loyal to the slaveholder and supported paternalism.

On the plantation, a cultural value that was brought to the Americas was the high regard for kinship networks that included established friendships. Joyner writes, "Friendship and altruism were held up as positive values within the slave community, but such traits were not exhibited by the tricksters in their social relations with the powerful." ${ }^{44}$ Although friendships were valued on the plantation, this tale teaches that not everyone in the slave community were friends which is the case for Uncle Jack and Jim whose friendship is unstable because of Jim's loyalty to paternalism. This tale imparts lessons about human interactions within the slave community with characters, Uncle Jack 
and Jim. Although both meet to enjoy music as a form of entertainment after their tasks are completed, it is Jim who helps Master Sipsey punish Uncle Jack. Like Jim, many slaves were more interested in developing a relationship with the slaveholder than with the slave. It is not certain whether or not Jim is identified as a slave overseer or driver, but it is evident that he has some form of authority in helping manage the behavior of Uncle Jack. As a result, Jim indirectly represents a type of overseer or driver on the plantation. Genovese provides the expectations of slaves who were relied on as trustworthy:

Overseers expected the hands to help them subdue one of their number $s$ who resorted to physical resistance. Usually they did assist in subduing a rebel, either because they feared punishment or because they feared that the overseer would shoot the resistant slave, or because they thought the overseer justified in a particular case, or because they hated the slave in question, or because of any combination of these reasons. Yet, sometimes they refused to intervene or helped the victim to escape. ${ }^{45}$

John W. Blassingame explained that there were untrustworthy slaves on the plantation. Slaves who were loyal to the slaveholder were outcasts in the slave community. Such an account examines how friendship on the plantation was at times, problematic. This human tale is similar to many true stories that detail rebellious slaves who challenged racial oppression. According to planter, David Gavin of South Carolina in 1861, a male slave named Big Jim who never got into any trouble on the plantation, finally rebelled against Gavin who "corrected" him for overloading a wagon. Big Jim physically bit Gavin, and ran away. Gavin regretted treating Big Jim cruelly. ${ }^{46}$ Many slaves on South Carolina plantations rebelled against using the gang system. Due to this rebellion, the task system replaced the gang system. 
Today, "Den To De Fiah" teaches several lessons relevant to the Gullah community. This tale teaches a realistic lesson about interracial and intra-racial relationships including friendship and trust-building. This tale teaches that, "A good friend is, of course, a trusted and loyal companion. But not all loyalties stem from solid friendships. Some loyalties are merely ceremonial. However, a person of high moral character will uphold a sworn allegiance regardless of whether it involves people who are likable or unlikable, friendly or unfriendly. ${ }^{, 47}$ This tale teaches children to carefully choose their friends. It teaches children how people can one day be your friend and the next, be your enemy which describes Uncle Jack and Jim's relationship. The moral lessons and cultural values imparted teach children to recognize positive and negative attributes within friendships. Such recognition helps determine sustaining companionship as is both loyal and trustworthy to the right person.

\section{BUILDING CHARACTER: COURAGE, BRAVERY, AND RESILIENCY}

Three tales are explored: the animal tale "Buh Lion and Buh Goat," the human tale, "John Saves Old Masters Children," and another human tale, "The People Could Fly." "Buh Lion and Buh Goat," an escape and trickster tale, is a great example of courage, bravery, and resiliency. Buh Goat stands up to Buh Lion, his oppressor, by demanding that Buh Lion respect him. This tale explains that bravery means facing one's fears. It means stepping out on faith and believing in oneself. "John Saves Old Master's Children" is an escape and trickster tale that teaches a number of lessons about the bravery, courage, and resiliency with the primary lesson being using trickery to attain freedom. These lessons help children overcome adversity such as racism and oppression. 
"The People Could Fly" is a cautionary, escape and trickster tale that imparts lessons about the power of faith, community, and memory to achieve emancipation. This tale teaches children to remember that their ancestors were brave, courageous, and resilient in Black communities such as the Gullah community. This tale teaches children to appreciate their unique African heritage. This tale motivates children to believe that like their ancestors, they too can "fly" and prevail over racism and oppression. These three tales are testimonies that courage is the trait that replaces fear during adversity. ${ }^{48}$ These tales realistically portray the Black community as tenacious.

\section{Buh Lion and Buh Goat}

Buh Lion notices that Buh Goat is relaxing and enjoying the day while lying on top of a large rock and chewing something interesting. The fact that Buh Goat is minding his own business and eating something astonishes Buh Lion. Buh Lion continues to spy until he creeps up on the timid Buh Goat to ask what he is eating. Although Buh Lion is known for his confidence and physical strength, and Buh Goat is known for his apprehension and physical weakness, Buh Goat faces his fears. He speaks powerfully to Buh Lion stating that he is chewing on a rock, and if he knew any better, he would mind his business, or else he would chew and eat Buh Lion. This is a bold statement that makes Buh Lion contemplate whether or not Buh Goat is capable of chewing through a rock, let alone him. With this threat, Buh Lion retreats from his initial trickster motives and walks away. Buh Lion is taught a lesson through Buh Goat's newfound confidence. The moral lesson to this tale is, "A bold man gets out of his difficulties, a coward loses his life.",49

On the plantation, this escape and trickster tale was used to teach multiple lessons. 
Buh Lion physical strength represents the slaveholder and Buh Goat's physical weakness represents the slave. The slaveholder represented authority while the slave represented powerlessness. However, Buh Goat is mentally strong because he is no longer insecure but self-confident. This tale also teaches the lesson that perception is reality. Although Buh Goat is afraid, he does not show it. He remains brave to overcome his circumstance which is a trait which many persons embrace in order to rise above problems. ${ }^{50}$ Buh Goat is audacious, but he is not completely fearless. Even courageous people are at times fearful. Courageous people do not focus on weakness but strengths. Buh Goat represents slaves who resisted fought for freedom and justice.

Today, this tale imparts the same lessons in a different social context. High selfesteem is a key characteristic of Buh Goat. Self-esteem derives from a sense of "pride, self-respect, and self-satisfaction. Self-esteem blossoms or wilts with confidence in your ability to carry out your own plans, or fulfill an intention." ${ }^{\text {51 }}$ The moral lessons and cultural values imparted teach children to refrain from cowardice and exert courage and bravery. This tale teaches that no matter the magnitude of fear, self-confidence and perseverance allows one to triumph through adversity.

\section{John Saves Old Master's Children}

John saves Old Master's children who are stuck on a boat in the middle of a lake that begins to turn over. When John explains that the children are in danger, the children's mother, Ole Missy is not alarmed. Compared to Ole Missy, Old Master and John are frantic. However, between the two, it is John who takes the initiative to save the children. For such heroism, Old Master promises John his freedom upon filling the barn 
with a year of crops. John completes the task and is granted his freedom. Hitherto, the moral of the tale does not surface until John begins to walk towards Canada [a symbol of emancipation] as a free man. During his walk toward freedom, Old Master uses trickery to dissuade John from leaving the plantation by expressing that he along with his wife and children really love him, but at the end of the day, he is still a "good nigger."

This derogatory epithet is used by Old Master against John to promote paternalism. However, John does not fall for any of Old Master's trickery. Old Master's description of John as a "good nigger" is far from realistic and does not deter John from his goal in attaining freedom. Old Master is unaware that John also has trickster ways. He does not know that John played the submissive role in order to obtain his freedom. Duncan Clinch Heyward provided a South Carolina saying that describes the role of the trickster figure in the tale and realistically, "De buckruh [whites] hab scheme, en de nigger hab trick, en ebery time de buckruh scheme once de nigger trick twice." ${ }^{, 52}$ This quote explains the hidden agenda of slaves such as John.

On the plantation, this human tale was used to teach children about duality which consisted of acting a certain way in front of the slaveholder, and another way in the slave community. Du Bois believed that "double consciousness" could be difficult since it required Black persons to weave through social systems as both loyal and disloyal to White persons. ${ }^{53}$ This understanding of identity helped many slaves secure their freedom which is true for characters such as John who was a role model because he never stopped walking toward Canada. Moreover, this escape and trickster tale teaches a lesson about focusing on the attainment of a goal by being strong-willed and fearless. Joyner writes, "But the slave trickster is not satisfied with outwitting Old Maussa, gaining his freedom, 
and acquiring wealth and power. The quest is for status." ${ }^{54}$ This quote implies the importance of pride.

This tale imparts lessons about economic and psychological oppression. This tale describes the capitalistic operation of the institution of slavery. John's labor on the plantation is only viewed economically. Old Master expects John to tend to his children, and complete tasks such as filling a barn with a year of crops to accumulate wealth on the plantation. Although slaveholders classified slaves merely as commodities, respect was anticipated within the slave community. ${ }^{55}$ Additionally, this tale teaches about psychological oppression with the description of John and Old Master's relationship. Old Master and John are both tricksters. Old Master predicts that John will stay on the plantation if he calls him a "good nigger." This racial epithet encourages paternalistic characteristics such as dependency and contentment. For many slaveholders, a "good nigger" was a high honor for the slave. The "good nigger" did not rebel, but was reliable to the slaveholder. Genovese described slaves who used "double consciousness" as a method of trickery to play the role of the "good nigger." He writes:

From the black point of view, there is a great difference between being a 'good Negro" and being a 'white man's nigger.' The latter, in fact, is often brutal in his relations with blacks and dependent upon white protection to keep him from having to answer for crimes and outrages. This type, which has had a long history in every class society, appeared frequently on the slave plantations. ${ }^{56}$

In "John Saves Old Master’s Children," Old Master's trickster motives are unsuccessful because John is also a trickster who has learned to show Old Master one side of his personality and leave another side hidden as a type of duality or "double consciousness." According to Roberts, "Whether John emerged victorious over Old 
Master or appeared as a numskull over whom Old Master triumphed was less important in their evaluation of John's actions than the fact that the tales revealed the master-slave relationship as one which justified trickster-like behavior."57

This human tale teaches several lessons about the historical and contemporary implications of interracial human interactions. The moral lessons and cultural values imparted in this tale teach children to view John as a positive role model because he remained committed to achieving freedom and persevered despite his difficult life on the plantation.

\section{The People Could Fly}

On a large-cotton producing Sea Island plantation is a slave community. The slaves are overworked and weak from strenuous labor. They plow the fields as resident owners including the master, overseer, and driver manage the plantation. They are the harshest of slaveholders in the town. When a woman, who has just given birth, carrying her newborn baby on her back, falls into the field from exhaustion, she and her baby are severely whipped back to work. When the baby cries, she throws her breast over her shoulder to sooth the baby, whispers foreign words into the baby's ear, and continues to work. However, it is not long before she again becomes weak, stumbles, and falls to the ground. She and her baby are severely lashed by the slaveholders. Once she gains strength to rise to her feet, she confides in the oldest male slave on the plantation. They speak in a language that is foreign to the slaveholders. Soon, the young woman falls again, and is lashed. Again, she speaks to the old man, and is encouraged to stay strong. However, the third time she falls, and is lashed, she responds differently. After she and 
her baby are whipped, she asks the old man if it is time. The old man agrees, and she and he baby take to the sky, flying away from the plantation. The slaveholders run after her but it is too late. She had flown past the sun.

After experiencing this, the slaveholders walk back to the field hands to make sure work is getting completed, but soon, a male slave falls from exhaustion, and he too is lashed severely. When he gains enough strength to stand, the old man speaks to him in the same foreign language. The slaveholders tell the man to return to his work area. Instead, he laughs in their faces, and rises to the sky to fly away as the young woman had. Another slave falls from weakness and listens to the old man's words. He also flies away. It is then that the slaveholders label the old man who speaks in the foreign tongue as responsible for the flight of the slave. They order him to receive severe lashes, but as they approach, the old man laughs in their faces. He speaks in a secret language known to the old slaves on the plantation. When he speaks, he lifts his arms unleashing a secret that permits the old slaves to remember the power that they always owned to fly back to Africa; women with babies, fly with their children suckling at their breasts. As they fly, the new slaves born on the plantation watch in fear of their lives because they either can't remember the words, or were never taught to fly. When the old man looks back at the poor souls who are left, he encourages them to run for their freedom. On the plantation, and after freedom, the tale of the flying Africans was passed down to children. And, today, it is still told.

"The People Could Fly" is a cautionary, escape, and trickster tale that teaches lessons about life on the plantation, the importance of freedom, memory, the preservation of African heritage, and the repercussions of not transmitting African cultural traditions 
to children. On the plantation, this tale was realistic in describing life on many large cotton-producing residential owner plantations that used the task or gang system on the Sea Islands. Barboza writes about the conditions on the plantation:

Slaves survived beatings, torture, and back-breaking labor under the hot sun. They worked from 'can to can't' (from 'can' see at sunrise to 'can't see at night), reaching deep within for strength and stamina. Even if they were planting cotton or digging a ditch, their work became an expression of their own great nobility. And when slaves did not reap rewards for their toil and trouble, many considered that they might get it 'by and by,' in heaven. ${ }^{58}$

"The People Could Fly" is realistic in its description of physical punishment that often led to death which is in complete opposition to the idea of paternalism on the plantation. This method of slave labor on the cotton plantation caused many slaves to resist in large numbers of the severe living conditions on the plantation. Insurrection was an issue facing many large plantations. According to Genovese, "No plantation of any size totally avoided the runaway problem. Everywhere, the slaveholders had to build a certain loss of labor-time and a certain amount of irritation into their yearly calculations." 59 Furthermore, Genovese writes about the role of the slaveholders, "And worst of all were the drivers for the slave traders, who ranked, along with their masters, as the friends of the regime. Their brutality provided a conjuncture for two of the three meanings of the word 'driver' in the Old South; it could also mean a slave trader or a carriage driver." ${ }^{60}$ Moreover, "Slaves ran not simply from a particular whipping but from the torments regularly inflicted by cruel or sadistic masters or overseers. ${ }^{, 61}$ Barboza writes, "Blacks were expected to aspire to no more in life than hard, back-breaking labor for others." This quote alludes to the realistic experience of life on the plantation that 
included the quest for freedom. ${ }^{62}$

This tale describes the slave's inherent power that is accessed with memory. Although slaves from Angola were believed to possess supernatural powers, this inherent power was equally distributed throughout the slave community but only available if remembered. The old man who is an African slave possesses the ability to fly permitting their escape to freedom. It is suggested that their ability to fly is suppressed with the harsh realities of the middle passage and life on the plantation. With this suppression, many slaves shed their wings or forgot they owned them. This was a consequence of the institution of slavery. However, with this hidden trait of being African, slaves were able to gain freedom. According to Hazel Arnett Ervin, the flying African is "A tale that recounts the belief in the ability of native-born Africans to call on a special-African derived power to lift them up from the burden of slavery in America and return them to Africa. As myth, the suggestion is that the African American is bound in body and weighed down in chains, but his spirit is not to be enslaved." ${ }^{63}$ However, it is still preserved, allowing them to rise above their circumstances. This survival represents the African cultural traditions that were hidden and preserved on the plantation. According to Virginia Hamilton, “A plausible explanation might be the slaves running away from slavery, slipping away while in the fields or under cover of darkness. In code language murmured from one slave to another, 'Come fly away!' might have been the words used. Another explanation is the wish-fulfillment motif." 64 The old slaves had the power to fly or overcome their circumstances meaning that they retained their African heritage, but did not transmit it to the new generation of slaves who did not have a memory of Africa because they were born on the plantation. To illustrate, while many slaves could attest to 
a former life on the African continent, the most memorable were personal narratives extracted from the tales that detailed life in Africa and slavery in America. For those born into slavery, oral narratives detailed the "old country" or Africa. Such a recollection provided persons born into slavery the indigenous history, culture and language of Africa. This tale was told to inspire children to preserve African memory that included their history, culture, and identity. With such a profound memory one could secretly resist slavery. This tale was a testament that all slaves had the power to escape slavery whether it was through flying or running away. ${ }^{65}$

Today, the moral lessons and cultural values imparted from this tale teaches children to remember and appreciate their resilient ancestors, African cultural traditions, and the repercussions of not transmitting African history, culture, and identity in the family. It teaches children the importance of respecting elders who are the carriers of the African heritage. It also teaches children about their inherent strength, resiliency, and tenacity. Barboza explains that, "Tenacious people are nearly impossible to defeat, turn down, or turn around-they're as unyielding as the day is long."

Essentially, a large majority of these tales end with a hypothetical question, or direct moral statement used to educate and socialize children. However, no matter the content of the folktale, one aspect of the tale remained consistent: the ending. African folktales end with lessons that do not focus on living happily ever after but a to-becontinued conclusion. ${ }^{67}$ According to Joyner, it is most important not to:

Miss perhaps the central meaning of the trickster tales to the slaves; but to magnify that identification out of proportion-to take the trickster tales merely as vicarious protest tales-is to miss other levels of their meaning completely. That the animal tales provided slaves with a satirical depiction of the society in which they lived has been somewhat obscured by an 
overemphasis on similarities between the trickster and the slave. ${ }^{68}$

The moral truth in the tales' endings provides children examples of perseverance from an oppressed community. ${ }^{69}$ According to Barboza:

Though some stories might seem dated, they nevertheless relate values that are as vital today as they were yesterday. Other inclusions deal with slavery because the words of slaves may offer insights into our human condition today. Everyone can benefit from knowing certain harsh facts about American history, including slavery. ${ }^{70}$

Today, with the replacement of the institution of slavery with institutional racism, the underclass will need Brer Rabbit and John tales to impart moral lessons and cultural values to help educate and socialize children to deal with racial disparity and inequality. As a result, the same moral lessons and cultural values imparted from the tales told on the plantation are told today. The African folktales explored here are cultural adaptations that survived slavery to reflect the preservation of the Black experience in America. These animal and human tales teach children to foster resiliency and live approvingly by their ancestors. $^{71}$

This chapter provides a thorough literary and cultural analysis of six animal and four human tales comprised of moral lessons and cultural values that were adapted and transmitted generationally in Black communities such as the Gullah community during to educate and socialize Black children to survive adversity during slavery. The following chapter not only provides a summation of this research, but focuses on a current description of the South Carolina Sea Islands and its residents to assert that African folktales continue to educate and socialize Gullah children today. 


\section{CHAPTER VI}

${ }^{1}$ Lawrence W. Levine, Black Culture and Black Consciousness: Afro-American Folk Thought from Slavery to Freedom (New York, NY: Oxford University Press, 1977). 115.

${ }^{2}$ Julius Lester, On Writing for Children \& Other People (New York: NY: Dial Books, 2004).73; Steven Barboza, The African American Book of Values: Classic Moral Stories (New York, NY: Doubleday, 1998). 4-10.

${ }^{3}$ Terrell A. Young, Joseph Bruchac, Nancy Livingston, and Catherine Kurkjian. "Children's Books: Folk Literature: 'Preserving the Storytellers' Magic.” The Reading Teacher 57, no. 8 (2004): 782-792.

${ }^{4}$ Levine, Black Culture and Black Consciousness, 82.

${ }^{5}$ Wade W. Nobles, “African American Family Life: An Instrument of Culture," in Black Families, ed. Harriette Pipes McAdoo, Fourth Ed. (Thousand Oaks, CA: Sage Publications, Inc., 2007). 75-76.

${ }^{6}$ Barboza, The African American Book of Values, 743.

${ }^{7}$ Ibid., 249.

${ }^{8}$ Patricia Guthrie, Catching Sense: African American Communities on a South Carolina Sea Island (Westport, CT: Bergin \& Garvey, 1996). 47.

${ }^{9}$ Wilma King, Stolen Childhood: Slave Youth in Nineteenth-Century America. Bloomington, IN: Indiana University Press, 1995). 1.

${ }^{10}$ Barboza, The African American Book of Values, 250; John W. Blassingame, The Slave Community: Plantation Life in the Antebellum South. Revised and Enlarged Ed. (New York: Oxford University Press, Inc., 1972). 190.

${ }^{11}$ Harold Courlander, Afro American Folklore: The Oral Literature, Traditions, Recollections, Legends, tales, Songs, Religious Beliefs, Customs, Sayings and Humor of Peoples of African Descent in the Americas (New York, NY: Marlowe \& Company, 1976). 489.

${ }^{12}$ John D. Smith, "The Unveiling of Slave Folk Culture, 1865-1920," Journal of Folklore Research 21, no. 1 (1984): 54.

${ }^{13}$ V. Lynn Kennedy, Born Southern: Childbirth, Motherhood, and Social Networks in the Old South (Baltimore, MD: The John Hopkins University Press, 2010). 135.

${ }^{14}$ Barboza, The African American Book of Values, 744.

${ }^{15}$ Courlander, Afro American Folklore, 490.

${ }^{16}$ Barboza, The African American Book of Values, 743; Ibid., 65.

${ }^{17}$ Ibid., 743.

${ }^{18}$ Guthrie, Catching Sense, 45; Willie Lee Rose, Rehearsal for Reconstruction: the Port Royal Experiment (Indianapolis, IN: Bobbs-Merrill, 1964). 129.

${ }^{19}$ Courlander, Afro American Folklore, 488.

${ }^{20}$ Levine, Black Culture and Black Consciousness, 119.

${ }^{21}$ Eugene D. Genovese, Roll Jordan Roll: The World the Slaves Made (New York, NY: Random House, Inc., 1972). 651-652.

${ }^{22}$ Barboza, The African American Book of Values, 883.

${ }^{23}$ Ibid., 883.

${ }^{24}$ Ibid., 883; Levine, Black Culture and Black Consciousness, 300; Ralph Ellison, Shadow and Act (New York, NY: Random House, 1964). 54; Constance Rourke, American Humor: A Study of the National Character (New York, NY: Harcourt, Brace, and Company, 1931). 99; Ibid., 324.

${ }^{25}$ Levine, Black Culture and Black Consciousness, 301.

${ }^{26}$ Genovese, Roll Jordan Roll, 84.

${ }^{27}$ Levine, Black Culture and Black Consciousness, 300; Ellison, Shadow and Act, 47-48; Sterling Brown, The Negro in American Fiction (Washington, D.C.: The Associates in Negro Folk Education, 1937). 13.

${ }^{28}$ Rourke, American Humor, 100.

${ }^{29}$ Ellison, Shadow and Act, 54.

${ }^{30}$ Barboza quotes Langston Hughes, The African American Book of Values, 885.

${ }^{31}$ Melville Herskovits, an anthropologist who believed that racism was a product of psychological and socioeconomic problems.

${ }^{32}$ Hugh T. Keenan, "Joel Chandler Harris and the Legitimacy of the Reteller of Folktales," in Sitting at the Feet of the Past: Retelling the North American Folktales for Children, ed. Gary D. Schmidt and Donald R. 
Hettinga (Westport, CT: Greenwood Press, 1992). 83; Brown, The Negro in American Fiction, 56; Rourke, American Humor, 82.

${ }^{33}$ Anthony L. Manna, "Br'er Rabbit Redux" in Sitting at the Feet of the Past: Retelling the North American Folktales for Children, ed. Gary D. Schmidt and Donald R. Hettinga (Westport, CT: Greenwood Press, 1992). 98.

${ }^{34}$ Brown, The Negro in American Fiction, 55; Manna, "Br'er Rabbit Redux" 97.

35 " Henry L. Gates, Linda Goss, and Marian E. Barnes, ed. Talk that Talk: An Anthology of AfricanAmerican Storytelling. New York, NY: Simon \& Schuster, 1989). 101.

${ }^{36}$ Priscilla Jaquith, "Folktale Decisions" in Sitting at the Feet of the Past: Retelling the North American Folktales for Children, ed. Gary D. Schmidt and Donald R. Hettinga (Westport, CT: Greenwood Press, 1992). 77.

${ }^{37}$ Genovese, Roll Jordan Roll, 646.

${ }^{38}$ John W. Roberts, "African American Diversity and the Study of Folklore." Western Folklore 52. 2/4, (1993): 167.

${ }^{39}$ Courlander, Afro American Folklore, 490.

${ }^{40}$ Charles Joyner, Down by the Riverside: A South Carolina Slave Community (Urbana, IL: University of Illinois Press, 1984). 180.

${ }^{41}$ Ibid., 666.

${ }^{42}$ Genovese, Roll Jordan Roll, 628.

${ }^{43}$ David Pilgrim, "Who Was Jim Crow?" Jim Crow Museum at Ferris State University. Ferris State University, September 2000, accessed April 18, 2012, http://www.ferris.edu/jimcrow/who.htm; Isabel Wilkerson, The Warmth of Other Suns: The Epic Story of America's Great Migration (New York, NY: Random House, 2010). 40-41; Ellison, Shadow and Act, 40.

${ }^{44}$ Joyner, Down by the Riverside, 176.

${ }^{45}$ Ibid., 623.

${ }^{46}$ Blassingame, The Slave Community: Plantation Life in the Antebellum South, 316; Genovese, Roll Jordan Roll, 620.

${ }^{47}$ Barboza, The African American Book of Values, 833.

${ }^{48}$ Ibid., 65.

${ }^{49}$ Courlander, Afro American Folklore, 490.

${ }^{50}$ Barboza, The African American Book of Values, 65.

${ }^{51}$ Ibid., 215.

${ }^{52}$ Duncan C. Heyward, Seed from Madagascar (Chapel Hill, NC: University of North Carolina Press, 1937). 165.

${ }^{53}$ W. E. B. Du Bois, The Souls of Black Folk (Rockville, MD: Arc Manor, 1964). 12.

${ }^{54}$ Joyner, Down by the Riverside, 187.

${ }^{55}$ Barboza, The African American Book of Values, 793.

${ }^{56}$ Genovese, Roll Jordan Roll, 629.

${ }^{57}$ John W. Roberts, From Trickster to Badman: The Black Folk Hero in Slavery and Freedom (Philadelphia, PA: University of Pennsylvania Press, 1989).61.

${ }^{58}$ Barboza, The African American Book of Values, 249.

${ }^{59}$ Genovese, Roll Jordan Roll, 653.

${ }^{60}$ Ibid., 372.

${ }^{61}$ Ibid., 649 .

${ }^{62}$ Barboza, The African American Book of Values, 19.

${ }^{63}$ Hazel Arnett Ervin, The Handbook of African American Literature (Gainesville, FL: University Press of Florida, 2004). 62.

${ }^{64}$ Virginia Hamilton, The People Could Fly: American Black Folktales, Illus. Leo Dillon and Diane Dillon (New York, NY: Alfred A. Knopf, 1985). 172.

${ }^{65}$ Hamilton, The People Could Fly, 172-173.

${ }^{66}$ Barboza, The African American Book of Values, 313.

${ }^{67}$ Roger Abrahams, ed. Afro-American Folktales: Stories From Black Traditions in the New World (New York, NY: Pantheon Books, 1985). 3.

${ }^{68}$ Joyner, Down by the Riverside, 175.

${ }^{69}$ Abrahams, Afro-American Folktales, 118; Jan Carter-Black, "Teaching cultural competence: An 
innovative strategy grounded in the universality of storytelling as depicted in African and African

American storytelling traditions." Journal of Social Work Education 43, no.1 (2007): 34; Abrahams, AfroAmerican Folktales, 4.

${ }^{70}$ Ibid., 11.

${ }^{71}$ Lester, On Writing for Children \& Other People, 107; Jeffrey W. Bolster, Black Jacks: African American Seamen in the Age of Sail (Boston, MA: Harvard University Press, 1997). 142; Thomas A. Green, ed. African American Folktales (Westport, CT: Greenwood Press, 2009). Preface. 


\section{CHAPTER VII}

\section{SUMMARY AND CONCLUSION}

The survival of African people away from their ancestral home is one of the great acts of human endurance in the history of the world. ${ }^{l}$

This chapter is a summation of the research that explored the development of Black cultural space and its influence on the historical and contemporary function of African folktales as a method to educate and socialize Gullah children on the South Carolina Sea Islands. This research recognizes the significance of African folktales by using a socio-cultural historical lens to understand the presence of Black identity in a White world.

\section{THE GREAT MIGRATION}

During slavery, large White-absentee plantations that used the task system offered slaves "free time" to pursue recreational activities that isolated them from White persons and helped them organize small communities of Black autonomy. The constant influx of African persons from the same region of West Africa renewed African history, culture, and identity by enabling slaves to both preserve their African heritage and maintain a strong kinship and family structure through catching sense that is a type of rites of passage that helped to successfully guide children as they developed into adulthood. ${ }^{2}$

Furthermore, the preservation of family and kinship was also present during pre- 
reconstruction. During this time, the status of persons of African descent changed from slave to contraband. As a result, the involvement from government officials was required not only to protect the contrabands new status, but their forthcoming rights as citizens. For example, General William Tecumseh Sherman's Special Field Order No. 15 helped provide newly emancipated persons with forty acres and a mule as a form of restitution. Although the proposal was short-lived, since the annulment, the African American population has undergone many forms of oppression which have led to the emergence of the Great Migration. ${ }^{3}$

According to Isabel Wilkerson, the Great Migration roughly spanned from 1915 to 1975. It was a "mass relocation" and demographic resettlement of southern Black persons. These persons migrated within two distinct wave patterns that lasted roughly 30 years each. She describes the first wave that lasted from 1915 to the 1930s as "a silent pilgrimage." Wilkerson writes that, in the 1920s, 903,000 African Americans from the South migrated to the North. In the 1930 s, there were 480,000 Black migrants. This wave that was during the WWI era (1914-1918) and the Great Depression motivated newly emancipated persons to migrate from the South to non-Southern states and from rural areas to the city for better civil treatment and economic opportunities. Although this wave has received the most attention from historians, the second wave was the largest. ${ }^{4}$

The second wave that lasted from 1940 to the 1970s was during the WWII era (1939-1945). As the largest migration, approximately 6 million Black persons traveled from the South to the Northeast, Midwest, and West. Wilkerson also uses census data to provide statistics on the migration patterns of Blacks for the second wave of the Great Migration. For example, in the 1940s, there were 1.6 million Black migrants. In the 
1950s, there were 1.4 million migrants. Particularly, in South Carolina, the out-migration of African Americans was a response to the in-migration of White persons that soared with the establishment of connector bridges and the availability of air conditioning throughout various Sea Islands. In the 1960s, there were 1 million African American migrants. This migration was possible because there were three primary water transport systems that reached northern and western states made it possible for southern African Americans to migrate to the North. One stream system that was located along the southeastern coast traveled through states such as South Carolina to northeastern cities such as New York, Philadelphia, and the District of Columbia. ${ }^{5}$

In South Carolina, one of the main reasons for the out-migration of Gullahspeaking persons was the lack of employment opportunities. For example, after the boll weevil destroyed a number of southern cotton fields, sharecropping was no longer required. As a result, African Americans were motivated to migrate to the North mainly for better living conditions and job opportunities. However, towards the end of the Great Migration in the mid-1970s, Wilkerson has stated that many African Americans returned to the South after the passage of the Civil Rights Act of 1964 that led to the termination of Jim Crow laws in the American South. ${ }^{6}$ While African Americans returned to the South to visit family and friends temporarily, others returned to live. For example, many African American children whose parents traveled North or West particularly during the second wave of the Great Migration, desired to return to the South. Despite this interest, the out-migration of Gullah persons continues to increase. ${ }^{7}$

Since the end of the Great Migration, land developers have encouraged Gullah persons to sell their land to further develop the growing tourism economy on the Sea 
Islands. The development of new military reservations and bases on Black-owned land and the work of land developers that promote urbanization with the establishment of resorts and tourism on Sea Islands such as Hilton Head have impacted the economy in South Carolina and helped increase violence and crime. ${ }^{8}$

\section{THE SEA ISLANDS TODAY}

The South Carolina Sea Islands that were once inhabited by a predominately African American community are now inhabited by a large White population interested in land development that promotes resorts, tourism, military reservations, and private communities that economically benefit new White residents and exploit the Gullah community. As a result, Black land owners remain threatened by White developers who are economically invested in establishing vacation and retirement homes behind gated communities that further contribute to Black land loss and the out-migration of African Americans on the South Carolina Sea Islands. According to the National Park Service (NPS), the Georgia and South Carolina Sea Islands are estimated as having an African American population of 652,701 in 2005. The 2000 U.S. Census Tracts of South Carolina and the 2010 U.S. Census Bureau also provide evidence of White and Black presence on the Sea Islands referenced in this research to provide evidence that Gullah-speaking persons continue to reside on the Sea Islands (see appendix). This research focuses on five of 16 South Carolina Sea Islands including: Daufuskie Island (the only residential Sea Island in South Carolina), St. Helena Island, Hilton Head Island, Johns Island, and Sullivan's Island. These Sea Islands that once had a majority African American population now have a large White population. ${ }^{9}$ 
Daufuskie Island is the only residential "Sea Island." Accessible via water transportation, this island is located between Savannah, Georgia and Hilton Head Island in Beaufort. In the late $19^{\text {th }}$ century and early $20^{\text {th }}$ century, an oyster canning factory was opened to provide labor for the predominately African American community that consisted of nearly 2,000 residents. After pollution ended oyster harvesting on the island leaving majority of Gullah speakers without work, the African American population began to decline. Although 2010 census data for Daufuskie Island is not available, it is estimated that the population is approximately 250 with less than 20 persons representing the Gullah community. This island is comprised of two resorts, a gated residential community, and underdeveloped land plots intended for residential property. Despite the out-migration of African Americans, Daufuskie Island remains known for its Gullahspeaking population. ${ }^{10}$

St. Helena Island is the largest Sea Island in Beaufort. According to the 2010 U.S. Census Bureau, 33.9 percent of the population is African American. Due to the inmigration of White persons, the island is known for its developing resort amenities that support the tourism industry while contributing to the out-migration of African Americans. Despite the out-migration of African Americans and in-migration of White persons who are interested as land developers in improving the Sea Islands economy, African American or Gullah culture remains at the center of the island. Although it is growing economically, regulations help protect and preserve the rich historical and cultural features of the island that include a focus on the presence of Gullah-speaking persons. For example, the installation of condominium facilities and gated communities are prohibited on the island. Coffin Point where Coffin Point Plantation was located is 
one of the communities on the Island. ${ }^{11}$

Hilton Head Island, a point near the entrance of Port Royal, is a resort town located in Beaufort. During Reconstruction, the island not only provided a military hospital built by Union soldiers, but the island was a place where Blacks could buy land, gain an education, receive governmental housing, and join the Port Royal Relief Committee as volunteers. Today, Hilton Head is comprised of 12 miles of oceanfront landscapes of the Atlantic Ocean which makes it an ideal summer vacation destination, a time when the population is largest. According to the 2010 U.S. Census Bureau, less than 10 percent of the population is African American. Although Hilton Head offers several public beaches and island parks, over fifty percent of the island is located within small, gated communities with a predominately White population. However, since the development of the Sea Pines Resort in 1956, which is known for serving as a stop on the PGA Tour during the Heritage Golf Classic, the island has become known as a resort town comprised of private "plantations" such as Indigo Run Plantation and Spanish Wells Plantation. Moreover, while the promotion of resorts, tourism, and gated communities further establishes Hilton Head as a prototype for resorts around the country, the culture of African Americans who identify as Gullah persons on the island is threatened. ${ }^{12}$

Johns Island is located off the coast of Charlestown. According to the 2010 U.S. Census Bureau, 28 percent of the population is African Americans. Historically, the area is known for its rice, indigo, and cotton-producing plantations. Although the island is located near downtown Charlestown, an urban area that interests land developers that have initiated resorts and private communities, majority of the island has managed to retain its rural charm. As a result, it is assumed that African Americans who could 
represent a Gullah-speaking population are unthreatened by land development present on other islands with resorts and gated communities. ${ }^{13}$

Sullivan's Island, a town in Charlestown, is comprised of a 0.8 percent African American population. This town is known for its position during the trans-Atlantic slave trade. As the largest slave port in North America, it is estimated that over 40 percent of slaves were traded on the island and dispersed throughout North America. As a result, it is believed that 50 percent of African Americans had ancestors who were traded on Sullivan's Island. Today, African cultural traditions are still retained and practiced in the African American community on this island even though the population is lower than 1 percent. For example, in Mount Pleasant, one of the most practiced African cultural traditions in the Gullah community is the production of sweetgrass baskets. These African-designed fanner baskets were used agriculturally and domestically to separate the hulls and chaff from the grain on rice plantations through a winnowing process. Sweetgrass basketry is of interest to industrialists whose tourism efforts exploit Gullahspeaking persons while economically benefiting White persons on the Sea Islands. Moreover, since the island has not undergone drastic land development that is most noticeable of other islands that encourage resorts and private residential communities, it is assumed that the African American population that could include Gullah speaking persons residing on the island, continue to practice their rich cultural heritage unthreatened to a degree. ${ }^{14}$

Presently, while urbanization operates to establish resorts and tourism on the Sea Islands, land retention and its influence on intact kinship and family patterns unique to the Gullah community remain threatened. Despite the declining African American 
population on the South Carolina Sea Islands, census data confirms that members of the Gullah community who remain on the Sea Islands have continued as avid preservationists of their rich African heritage. Not only do residents continue to celebrate their African heritage, but many who have left the state also return to the South Carolina Sea Islands for annual cultural festivals where African cultural traditions such as folktales are presented. A few of these festivals include: the "Native Islander Gullah Celebration" that is held on Hilton Head Island in February; the "Gullah Festival" that is the oldest and largest of the annual cultural festivals and is held in May on Beaufort's Waterfront Park; "Daufuskie Day" that is held on the island as a designated day for former Gullah speaking residents to return and celebrate their heritage is held in June; and "Heritage Days" that is celebrated at The Penn Center on St. Helena Island in November. The Gullah community has also received national recognition on the Nickelodeon Gullah Gullah Island television series and educational children's program was inspired by Daufuskie Island and filmed on the South Carolina Sea Islands.

Cultural festivals held on the Sea Islands challenge the tourism industry that develops resorts, tourist attractions, military installations, and gated communities that is contributing to the out-migration of Gullah persons throughout the South Carolina Sea Islands. Moreover, local, state, and federal organizations were established politically as a direct response and strategy to protect Black owned land against tourism. Dr. Emory Campbell, a former Executive Director of Penn Center who identifies as a Gullah person, describes the bond between Black owned land and kinship, "It [land] provides that sense of place so central to holding families together-that family compound which provides the physical connection so vitally important to this culture." 15 Five of these programs include 
the South Carolina National Heritage Corridor, Gullah/ Geechee Sea Island Coalition, the Daufuskie Island Historical Foundation, and the Gullah/ Geechee Cultural Heritage Corridor Commission, and the Gullah Geechee Group. ${ }^{16}$

In 1996, the U.S. Congress established the South Carolina National Heritage Corridor to help protect communities such as the Gullah community on the Sea Islands. This Corridor focuses on three cultural developments of the state to include the presence of European settlers throughout the antebellum South, the establishment and development of slavery, and the use of trade routes. With its focus on South Carolina history, it acknowledges the early influence of the settlers from the Barbados. ${ }^{17}$

In the same year, Marquetta L. Goodwine, a native of St. Helena Island, founded the Gullah/Geechee Sea Island Coalition. This coalition aims to "promote and participate in the preservation of Gullah and Geechee history, heritage, culture, and language; works toward Sea Island land re-acquisition and maintenance; and celebrates Gullah/Geechee culture through artistic and educational means electronically and via 'grassroots scholarship." In July 2000, Goodwine became the Chieftess of the Gullah/Geechee Nation known as "Queen Quet" on the Sea Islands. ${ }^{18}$ A year later, the Daufuskie Island Historical Foundation was organized to help sustain African cultural traditions on the island by the Gullah community themselves. This foundation is a non-profit organization that focuses that operates similar to a museum that holds artifacts, records, and resources used to further increase a cultural appreciation of the Gullah community of Daufuskie Island. $^{19}$

On October 12, 2006, the Gullah/Geechee communities received governmental assistance. Separate from the NPS, the federal commission was created by the 
Democratic Congressman representing South Carolina's District 6, James E. Clyburn, to help the Gullah/Geechee communities on a local, state, and federal level. The Gullah/Geechee Cultural Heritage Corridor Commission that is also referenced as the Low Country operates to protect the Gullah community for future generations by recognizing, supporting, and preserving African heritage. According to Congressman Clyburn, "The Gullah/Geechee culture is the last vestige of fusion of African and European languages and traditions brought to these coastal areas. I cannot sit idly by and watch an entire culture disappear that represents my heritage and the heritage of those who look like me. ${ }^{20}$ In 2009, the Gullah Geechee Group, a non-profit organization helped support the preservation of African heritage on the Sea Islands. The Gullah community remains the only Black community in the United States with a national designation. $^{21}$

These organizations have helped challenge the tourism industry and increase recognition and appreciation for African cultural traditions practiced among Gullah speakers throughout the Sea Islands. Due to the efforts of these organizations and members of the Gullah community, the interest in protecting African cultural traditions such as folktales attests to the importance of its adaptation and preservation within the Black family. For example, although Mary Burroughs no longer serves as the primary storyteller in the family; her daughter has taken on the role. ${ }^{22}$ Moreover, folktales are transmitted generationally to impart moral lessons and cultural values about trial and error, racial and cultural identity, family history, maintaining strong family relationships, and overcoming adversity. These tales are testaments of bravery and courage that teach lessons about African heritage and the importance of conquering racial injustice. ${ }^{23}$ 
According to Roger Abrahams:

The interest of these stories extends beyond a simple community response to a large-scale social process, for they are related not only to genre tales brought from the Old World but to particular family stories as well, reminiscent and anecdotes about how specific members of the family developed ways of getting by during the hardest of the hard times. ${ }^{24}$

The preservation of African folktales among insulated Gullah-speaking persons of the South Carolina Sea Islands makes them particularly resilient because they hold strongly to their West Africa roots. Mary A. Twining and Keith E. Baird write:

These cultural retentions, deeply rooted as they are in ancestral African folkways, are of considerable importance in the study of Sea Islands family life. For although they exist in syncretism form, these survivals are still eminently functional in the society; and at the same time, consciously and unconsciously, Sea Islanders clearly derive from them a reassuring sense of cultural and historical continuity. ${ }^{25}$

According to Steven Barboza, Thomas J. Brown and Kitty Green, the Gullah community is the most authentic representation of the African American experience. Folktales are examples of adaptation that mark them out from the rest of African descended persons in the United States.

\section{MELVILLE J. HERSKOVITS}

Anthropologist Melville J. Herskovits acknowledged the African past embraced by persons of African descent who, through the trans-Atlantic slave trade, were taken to the Americas. Herskovits believed that persons of African descent who were brought to the New World were resilient because they adapted to social conditions by merging African cultural traditions with European American cultural traditions to survive. ${ }^{26}$ His 
theory of cultural change helps dispel the idea that Black persons in the United States such as the Gullah-speaking persons are devoid of a distinct African heritage. He writes, "To give the Negro an appreciation of his past is to endow him with the confidence in his own position in this country and in the world which he must have, and which he can best attain when he has available a foundation of scientific fact concerning the ancestral cultures of Africa and the survivals of Africanisms in the New World."27

According to Herskovits's research on the implications of acculturation, the hostile contact between the slaveholder and slave began with the establishment of the trans-Atlantic slave trade. Slavery was the situation that allowed the process of acculturation to occur on the plantation. As a result, slave communities on the South Carolina Sea Islands merged their African cultural traits with the cultural traits of slaveholders to develop a creolized culture that transformed the African slave community to an African American community who identify as Gullah persons. The slave community embraced a bicultural identity that reflected the presence of "double consciousness." For example, their African cultural traditions that included folktales covertly modeled the benefits of acculturation.

Essentially, Herskovits theory of cultural change helped him prove that White persons and African Americans were carriers of influential traditions. He explained that on Sea Island plantations, both slaveholders and slaves learned from one another because acculturation is a two-way street. Herskovits recognized the Gullah community that maintained their rich African heritage despite their social conditions under racial oppression. His research was further supported by the collection of folktales that had been collected and additional elements of Black culture that were awaiting discovery by 
other researchers. Herskovits's theory of cultural change provides evidence that African survivals are valuable cultural tradition artifacts in Black communities such as the Gullah community on the South Carolina Sea Islands. ${ }^{28}$ He writes, "That such counterparts as these are found for explanatory tales and myths, as well as for the better-known African animal tales, would seem to indicate that the body of African mythology and folk tales has been carried over in even less disturbed fashion than has hitherto been considered the case." ${ }^{29}$ The research aims to provide more data on folklore in the Gullah community as Herskovits envisioned.

Wilbur Cross corresponded with Dr. Joseph Opala, an American Anthropologist and scholar of Gullah Studies who describes the contemporary Gullah community on the South Carolina Sea Islands:

The Gullah still form a strong, cohesive community in South Carolina and Georgia. It is true that their isolation has been breaking down for the past forty years. Many have left the rural areas for jobs in the cities. Young people are attending university and finding professional positions away from home. Television, telephones, bridges, good roads, and ferries have come to the once, most remote parts of the Gullah area - and many "old fashioned" customs have been lost. But the Gullah still hold to their special identity, and they still take pride in their common heritage. Those who have moved away often return for family gatherings to expose their children to grandparents, to Gullah lore, and to the local life. ${ }^{30}$

\section{RESEARCH FINDINGS}

This thesis began with two research questions that explored the three factors that contributed to Black cultural space on the plantation and its influence on the preservation and adaptation of African folktales that are reservoirs of African history, culture, and identity transmitted in Gullah communities of the South Carolina Sea Islands. The first 
research question is, what factors existed during the antebellum era which created Black cultural space that would have permitted the continuation of folktales over time? Three primary factors contributed to the development of Black cultural space: the influx of African slaves from the same geographical region of Africa, White absenteeism, and the task system as a method of slave labor. First, the influx of slaves from the same region of Africa helped create Black cultural space on South Carolina Sea Islands plantations. Slaveholders preferred slaves from the Windward coast, a rice-growing region of West Africa. These slaves were believed to specialize in the cultivation of rice because the countries in which they came from including Sierra Leone were nearly identical to South Carolina in geography and climate. As a result, slaves from this region and surrounding countries began to enter the Sea Islands in staggering numbers making rice the first major agricultural cash crop in South Carolina. However, the constant renewal of slaves from the same African countries on the Sea Islands helped to isolate the slave community who continued to preserve their African heritage. Second, White absenteeism contributed to the creation of Black cultural space because it was a direct response to the hazardous environmental conditions that surrounded rice-producing plantations that required water harvesting in mosquito infested marshes. Due to these conditions, slaveholders fled from their plantations to prevent the spread of deadly diseases such as malaria, yellow fever, and small pox. These slaveholders left behind large slave populations managed by overseers and drivers who were many times Black. Consequently, the combination of absentee owners and the cultural isolation of the slaves helped grant a certain degree of autonomy and freedom on Sea Islands plantations. Third, the task system that was a compromise between the slaveholder and slave that helped to track progress on the 
plantation and offered slaves incentives to pursue recreational activities once daily work quotas were completed created Black cultural space on Sea Islands plantations. During leisure, slaves adapted their African-derived cultural traditions that included folktales to life on the plantation. During the antebellum era, these three factors contributed to the development of Black cultural space that created Gullah-speaking communities that continue to preserve, practice, and protect African cultural traditions such as folktales on the South Carolina Sea Islands.

The second research question is, what moral lessons and cultural values were conveyed by African folktales directed at children during the time of slavery and in contemporary society among the Gullah community on the South Carolina Sea Islands? This research provided a literary and cultural analysis of ten African folktales that were summarized, analyzed, and interpreted along with a socio-cultural historical analysis of the unique Gullah experience to explain that the lessons imparted from these tales on the plantation remain the same today. These tales are testimonies of perseverance, courage, resiliency, and hope in the Gullah community of the South Carolina Sea Islands. Barboza writes, "Since the first black person set foot in America, African Americans have been waging a fierce battle not only for human rights or civil rights, but for thinking rights, too-for control over self-perception." ${ }^{31}$ These tales impart encouraging lessons about overcoming adversity during the existence of slavery, the Civil War, emancipation, Jim Crow, WWI and WWII, two great migrations, the civil rights era, and institutional racism that continues to influence the lives of Black Americans today. According to Henry Louis Gates, "The stories that we tell ourselves and our children function to order our world, serving to create both a foundation upon which each of us constructs our sense of reality 
and a filter through which we process each event that confronts us every day." 32 Today, African folktales remain a form of creative, Black resistance in America. ${ }^{33}$

This new research asserts that the development of Black cultural space has influenced the preservation and adaptation of African cultural traditions such as folktales that are found in recent collections of folklore. Since slavery, these tales have persisted just as the family system has to help educate and socialize children within Black communities. It is predicted that African folktales will continue to prepare children to fight institutional racism only with the maintenance of strong kinship and family patterns that help preserve the unique African history, culture, and identity that exists among African American communities that include Gullah persons on the South Carolina Sea Islands. 


\section{CHAPTER VII}

\footnotetext{
${ }^{1}$ Quote by John Henrik Clarke

${ }^{2}$ Guthrie, Catching Sense, 21-38; Mekada Graham, "The 'miseducation' of Black children in the British educational system-towards an African-centred orientation to knowledge," in Educating Our Black Children: New Directions and Radical Approaches, ed. Richard Majors (New York, NY: RoutledgeFalmer, 2001). 71-73.

${ }^{3}$ National Park Service, Low Country Gullah Culture Special Resource Study (Atlanta, GA: NPS Southeast Regional Office, 2005). 49-54; Willie Lee Rose, Rehearsal for Reconstruction: the Port Royal Experiment (Indianapolis, IN: Bobbs-Merrill, 1964). 327-331.

${ }^{4}$ Isabel Wilkerson, The Warmth of Other Suns: The Epic Story of America's Great Migration (New York, NY: Random House, 2010). 8-13; Wilkerson, The Warmth of Other Suns, 177-178.

${ }^{5}$ National Park Service, Low Country Gullah Culture Special Resource Study, F5-6; Ibid., 216-218.

${ }^{6} \mathrm{Jim}$ Crow laws lasted from the 1880 s to the 1960 's; Ibid., 10.

${ }^{7}$ Ibid., 9; Ibid., 178; Ibid., 413-459.

${ }^{8}$ Ibid., 216-217.

${ }^{9}$ National Park Service, Low Country Gullah Culture Special Resource Study, 62; Richard A. Long, "Gullah Culture Special Resource Study Statement of National Historical and Cultural Significance" in Low Country Gullah Culture Special Resource Study, National Park Service (Atlanta, GA: NPS Southeast Regional Office, 2005). 101; Cross, Gullah Culture in America, 152-154; South Carolina Budget and Control Board's Office of Research and Statistics, "South Carolina Community Profiles: Census Tracts," last modified 2011, http://sccommunityprofiles.org/.

10 "Island History." The Daufuskie Island Historical Foundation, last modified unknown. http://www.daufuskieislandhistoricalfoundation.org; "The Gullah of Daufuskie Island, SC: 300 Years of African American Life on Daufuskie Island, SC," The Daufuskie Island Historical Foundation, last modified 2010, http://daufuskieislandhistoricalfoundation.org/Gullah-of-Daufuskie.html.

${ }^{11}$ St. Helena Island CCD, Beaufort County, South Carolina, 2010 US Census Bureau Profile of General Population and Housing Characteristics, last modified 2010, http://www.factfinder2.census.gov/.

${ }^{12}$ Hilton Head Island Town, South Carolina, 2010 US Census Bureau Profile of General Population and Housing Characteristics, last modified 2010, http://www.factfinder2.census.gov/.; "Hilton Head Island History." Town of Hilton Head Island Beaufort County, South Carolina, last modified 2009. http://www.hiltonheadislandsc.gov/.

13 "Johns Island, South Carolina," South Carolina's Information Highway, last modified 2012. http://www.sciway.net/city/johnsisland.html; Johns Island CCD, Charlestown, South Carolina, 2010 US Census Bureau Profile of General Population and Housing Characteristics, last modified 2010, http://www.factfinder2.census.gov/.

${ }^{14}$ Melissa D. Hargrove, "Marketing Gullah: Identity, Cultural Politics, and Tourism," Master of Science thesis (Knoxville, TN: University of Tennessee, 2000); Peter Wood, Black Majority: Negroes in Colonial South Carolina from 1670 through the Stono Rebellion (New York, NY: W.W. Norton and Company, 1974). 61; Sullivan's Island town, South Carolina, 2010 US Census Bureau Profile of General Population and Housing Characteristics, last modified 2010, http://www.factfinder2.census.gov/.; "Sullivan's Island Historical and Architectural Inventory Survey Report 1987, Town of Sullivan's Island Official Website, last modified 2007-2008, http://www.Sullivan'sisland-sc.com/; National Park Service, Low Country Gullah Culture Special Resource Study, 64-67.

${ }^{15}$ Wilbur Cross, Gullah Culture in America (Westport, CT: Praeger, 2008). 17-20.

${ }^{16}$ Joko Sengova, "My Mother Dem Nyus to Plan' Reis: Reflections on Gullah/Geechee Creole Communication, Connections, and the Construction of Cultural Identity," in Afro-Atlantic Dialogues: Anthropology in the Diaspora, ed. Kevin A Yelvington (Santa Fe, NM: School of American Research Press, 2006). 230-242; National Park Service, Low Country Gullah Culture Special Resource Study, 68; Mary A. Twining and Keith E. Baird, "Introduction to Sea Island Folklife," Journal of Black Studies 10, no. 4 (1980): 395; Guthrie, Catching Sense, 5-28; Ibid., 122.

17 "About Us," South Carolina National Heritage Corridor, last modified 2012. http://www.scheritagecorridor.org/.
} 
${ }^{18}$ Cross, Gullah Culture in America, 161; National Park Service, Low Country Gullah Culture Special Resource Study, 95.

19 "The Gullah of Daufuskie Island, SC: 300 Years of African American Life on Daufuskie Island, SC." Last modified 2012. http://daufuskieislandhistoricalfoundation.org/Gullah-of-Daufuskie.html.

20 "About Us," Official Site Gullah/Geechee Cultural Heritage Corridor. Last modified 2012. http://gullahgeecheecorridor.org.

${ }^{21}$ Cross, Gullah Culture in America, 153-161; Roger Abrahams, ed. Afro-American Folktales: Stories From Black Traditions in the New World (New York, NY: Pantheon Books, 1985). 267.

${ }_{22}$ Thomas J. Brown and Kitty Green, Lessons Learned From the Gullah Experience: Powerful Forces in Education African American Youth (Columbia, SC: Brown Publishing, 1999). 21; Joyner, Down by the Riverside, 195; Steven Barboza, The African American Book of Values: Classic Moral Stories (New York, NY: Doubleday, 1998). 505-506; Lawrence W. Levine, Black Culture and Black Consciousness, xi; Joyner, Shared Traditions, 272.

${ }^{23}$ Herbert G. Gutman, The Black Family in Slavery and Freedom, 1750-1925 (New York, NY: Vintage Books, 1976). 50; John W. Blassingame, The Slave Community: Plantation Life in the Antebellum South, Revised and Enlarged Ed. (New York, NY: Oxford University Press Inc., 1972). 31; Charles Joyner, Shared Traditions: Southern History and Folk Culture (Urbana, IL: University of Illinois Press, 1999). 4. ${ }^{24}$ Abrahams, Afro-American Folktales, 265.

${ }^{25}$ Mary A. Twining and Keith E. Baird, "Sea Island Culture: Matrix of the African American Family," in Sea Island Roots: African Presence in the Carolinas and Georgia, ed. Mary A. Twining and Keith E. Baird, (Trenton, NJ: Africa World Press, 1991). 10.

${ }^{26}$ Melville J. Herskovits, R. Redfield, and Ralph Linton, "Memorandum for the Study of Acculturation," American Anthropologist 38, (1935): 149-151; Jeffrey W. Bolster, Black Jacks: African American Seamen in the Age of Sail (Boston, MA: Harvard University Press, 1997). 53; Charles Joyner, Shared Traditions: Southern History and Folk Culture (Urbana, IL: University of Illinois Press, 1999).195.

${ }^{27}$ Melville J. Herskovits, The Myth of the Negro Past (Boston, MA: Beacon Press, 1958). 32.

${ }^{28}$ Herskovits and Herskovits, The New World Negro, 7-11; Melville J. Herskovits and Frances S. Herskovits, The New World Negro: Selected Papers in Afroamerican Studies (Bloomington, IN: Indiana University Press, 1966). 149.

${ }^{29}$ Ibid., 275.

${ }^{30}$ National Park Service, Low Country Gullah Culture Special Resource Study, 61.

${ }^{31}$ Barboza, The African American Book of Value, 313.

${ }^{32}$ Henry Louis Gates, Linda Goss and Marian E. Barnes, ed. Talk that Talk: An Anthology of AfricanAmerican Storytelling (New York, NY: Simon \& Schuster, 1989). 17.

${ }^{33}$ Barboza, The African American Book of Value, 215; Ibid., 9; Gutman, The Black Family in Slavery and Freedom, 1750-1925, 46; Eugene D. Genovese, Roll Jordan Roll: The World the Slaves Made (New York, NY: Random House, Inc., 1972). 584; Barboza, The African American Book of Values, 5. 


\section{REFERENCES}

"About Us." http://gullahgeecheecorridor.org. Official Site Gullah/Geechee Cultural Heritage Corridor. 2012. Web. 12 April 2012.

"About Us," http://www.sc-heritagecorridor.org/. South Carolina National Heritage Corridor. 2012. Web. 5 June 2012.

Abrahams, Roger, ed. Afro-American Folktales: Stories From Black Traditions in the New World. New York, NY: Pantheon Books, 1985. Print.

Allen, W.R. "African American family life in societal context: Crisis and hope." Sociological Forum 10 (1995): 569-592. Print.

Barboza, Steven. The African American Book of Values: Classic Moral Stories. New York, NY: Doubleday, 1998. Print.

Barnett, Naomi and Gloria T. Blatt. "Anansi, A Hero For All Seasons.” Ed. Gloria T. Blatt. Once Upon a Folktale: Capturing the Folklore Process With Children. New York, NY: Teachers College Press, 1993. 152-164. Print.

Bascom, William R. "Acculturation Among the Gullah Negroes." American Anthropologist 43 (1941): 43-50. Print.

---. "Four Functions of Folklore.”The Study of Folklore. Ed. Alan Dundes. Englewood Cliffs, NJ: Prentice-Hall, Inc., 1965. 279-298. Print.

Berlin, Ira. "Time, Space, and the Evolution of Afro-American Society on British Mainland North America." The American Historical Review 85.1. (1980): 44-78. Print.

Billingsley, Andrew. Black Families in White America, Climbing Jacob's Ladder: The enduring legacy of African American families. New York, NY: Simon \& Schuster, 1992. Print.

Black-Carter, Jan. "Teaching cultural competence: An innovative strategy grounded in the universality of storytelling as depicted in African and African American storytelling traditions." Journal of Social Work 43.1 (2007): 31-50. Print. 
Blake, Tom. "Beaufort County South Carolina Largest Slaveholders From 1860 Slave Census Schedules and Surname Matches For African Americans on 1870 Census," http://freepages.genealogy.rootsweb.ancestry.com/ ajac/. Aug. 2001. Web. 21 April 2012.

---. "Charlestown County South Carolina Largest Slaveholders From 1860 Slave Census Schedules and Surname Matches For African Americans on 1870 Census," http://freepages.genealogy.rootsweb.ancestry.com/ ajac/. Aug. 2001. Web. 21 April 2012.

---. "Georgetown County South Carolina Largest Slaveholders From 1860 Slave Census Schedules and Surname Matches For African Americans on 1870 Census," http://freepages.genealogy.rootsweb.ancestry.com/ ajac/. Aug. 2001. Web. 21 April 2012.

---. "Orangeburg County South Carolina Largest Slaveholders From 1860 Slave Census Schedules and Surname Matches For African Americans on 1870 Census," http://freepages.genealogy.rootsweb.ancestry.com/ ajac/. Aug. 2001. Web. 21 April 2012.

Blatt, Gloria T, ed. Once Upon a Folktale: Capturing the Folklore Process with Children. New York, NY: Teachers College Press, 1993. Print.

Blassingame, John W. Slave Testimony: Two Centuries of Letters, Speeches, Interviews, and Autobiographies. Baton Rouge, LA: Louisiana State University Press, 1977. Print.

---. The Slave Community: Plantation Life in the Antebellum South. Revised and Enlarged Ed. New York, NY: Oxford University Press Inc., 1972. Print.

Blythe, Robert W., Emily Kleine, and Steven H. Moffson. "Charles Pinckney National Historic Site: Historic Resource Study." National Park Service, 2000. Print.

Bolster, W. Jeffrey. Black Jacks: African American Seamen in the Age of Sail. Boston, MA: Harvard University Press, 1997. Print.

Brewer, James Mason. “American Negro Folklore.” Phylon 6.4 (1968): 3-4. Print.

Brookes, Stella B. Joel Chandler Harris: Folklorist. Athens, GA: University of Georgia Press, 2009. Print.

Brown, Sterling. The Negro in American Fiction. Washington, D.C.: The Associates in Negro Folk Education, 1937. Print. 
Brown, Thomas J. and Kitty Green. Lessons Learned From the Gullah Experience: Powerful Forces in Education African American Youth. Columbia, SC: Brown Publishing, 1999. Print.

Carawan, Guy and Candie Carawan. Ain't You Got a Right to the Tree of Life: The People of Johns Island, South Carolina, their Faces, their Words, and their Songs. Athens, GA: University of Georgia Press, 1989. Print.

Comer, James P. and Alvin F. Poussaint. Black Child Care: How to bring up a healthy black child in American: a guide to emotional and psychological development. New York, NY: Simon \& Schuster, 1975. Print.

Colombo, Gary., Bonnie Lisle and Sandra Mano, Framework: Culture, storytelling and college writing. Boston, MA: Bedford Books, 2007. Print.

Courlander, Harold. Afro American Folklore: The Oral Literature, Traditions, Recollections, Legends, tales, Songs, Religious Beliefs, Customs, Sayings and Humor of Peoples of African Descent in the Americas. New York, NY: Marlowe \& Company, 1976. Print.

Creel, Margaret Washington. "A Peculiar People" Slave Religion and Community-Culture among the Gullahs. New York, NY: New York University Press, 1988. Print.

Cross, Wilbur. Gullah Culture in America. Westport, CT: Praeger, 2008. Print.

Curtin, Philip D. The Atlantic Slave Trade: A Census. Madison, Wisconsin: University of Wisconsin Press, 1969. Print.

Dance, Daryl Cumber. From My People: 400 Years of African-American Folklore. New York, NY: Norton, 2002. Print.

"Daufuskie Island, South Carolina, 2010 Demographic Profile Data." http://www.factfinder2.census.gov. U.S. Census Bureau, table, DP-1 Profile of General Population and Housing Characteristics, 2010. Web. 30 May 2012.

Dorson, Richard M. American Negro Folktales. Bloomington, IN: Indiana University Press, 1956. Print.

Du Bois, W. E. B. The Souls of Black Folk. Rockville, MD: Arc Manor, 1964. Print.

Dundes, Alan. "The Functions of Folklore."The Study of Folklore. Ed. Alan Dundes. Englewood Cliffs, NJ: Prentice-Hall, Inc., 1965. 277-278. Print. 
---. Interpreting Folklore. Bloomington, IN: Indiana University Press, 1980. Print.

---. The Study of Folklore. Englewood Cliffs, NJ: Prentice-Hall, Inc., 1965. Print.

Eagleton, Terry. Literary Theory: An Introduction, Anniversary ed. Minneapolis, MN: University of Minnesota Press, 2008. Print.

Edelman, Marian Wright "A Portrait of Inequality." Ed. Harriette Pipes McAdoo, Black Families. Fourth ed. Thousand Oaks, CA: Sage Publications, Inc., 2007. 319-327. Print.

Ellison, Ralph. Shadow and Act. New York, NY: Random House, 1964. Print.

Ervin, Hazel Arnett. The Handbook of African American Literature. Gainesville, FL: University Press of Florida, 2004. Print.

Evans, David. "The Reinterpretation of African Musical Instruments in the United States." Ed. Okpewho, Isidore, Carole Boyce Davies, Ali A. Mazrui. The African Diaspora: African Origins and New World Identities.

Bloomington, IN: Indiana University Press, 1999. 379-391. Print.

Felluga, Dino. "Module on Stephen Greenblatt: On History." http://www.purdue.edu/guidetotheory/newhistoricism/modules/greenblatth istory.html. Introductory Guide to Critical Theory, 2011. Web. 29 July 2012.

Fish, Stanley. There's No Such Thing As Free Speech: And It's a Good Thing, Too, Part 8. New York, NY: Oxford University Press, Inc., 1994. Print.

Forten, Charlotte. The Journals of Charlotte Forten Grimke. Ed., Brenda Stevenson. New York: NY: Oxford University Press, 1988. Print.

---. "Life on the Sea Islands, Part I." Atlantic Monthly XIII (1864): 587-596.

Foster, James R. Great Folktales of Wit and Humor. New York, NY: Harper \& Brothers, 1955. Print.

Franklin, John Hope. "African American Families: A Historical Note.” Ed. Harriette Pipes McAdoo, Black Families. Fourth ed. Thousand Oaks, CA: Sage Publications, Inc., 2007. 3-6. Print.

Gates, Henry Louis., Linda Goss, and Marian E. Barnes, ed. Talk that Talk: An Anthology of African-American Storytelling. New York, NY: Simon \& Schuster, 1989. Print. 
Genovese, Eugene D. Roll Jordan Roll: The World the Slaves Made. New York, NY: Random House, Inc., 1972. Print.

Gershenhorn, Jerry. Melville J. Herskovits and the Racial Politics of Knowledge. Omaha, NE: University of Nebraska Press, 2004. Print.

Gibbs, Tyson. "Ethnographic and Ethnohistorical Report on Snee Farm, Charles Pinckney National Historic Site." National Park Service. Denton, TX: University of North Texas, Oct. 2006. Print.

Gonzales, Ambrose E. The Black Border: Gullah Stories of the Carolina Coast. Columbia, SC: The State Company, 1922. Print.

Goodwine, Marquetta L. Frum Wi Soul Tuh de Soil: The Cash Crops of the Sea Islands, Gullah/Geechiee: Africa's Seed in the Winds of the Diaspora, Volume III. Beaufort, SC: Kinship Publications, 1999. Print.

Graham, Mekada. "The 'miseducation' of Black children in the British educational system-towards an African-centred orientation to knowledge," Ed. Richard Majors. Educating Our Black Children: New Directions and Radical Approaches. New York, NY: RoutledgeFalmer, 2001.61-78. Print.

Green, Thomas A., ed. African American Folktales. Westport, CT: Greenwood Press, 2009. Print.

Guthrie, Patricia. Catching Sense: African American Communities on a South Carolina Sea Island. Westport, CT: Bergin \& Garvey, 1996. Print.

---. "Catching Sense" and the Meaning of Belonging on a South Carolina Sea Island, Ed. Shelia Walker, In African Roots/ American Cultures. Lanham, MD: Rowman and Littlefield, 2001. 275-282. Print.

Gutman, Herbert G. The Black Family in Slavery and Freedom, 1750-1925. New York, NY: Vintage Books, 1976. Print.

Hamilton, Virginia. The People Could Fly: American Black Folktales. Illus. Leo Dillon and Diane Dillon. New York, NY: Alfred A. Knopf, 1985. Print.

Hargrove, Melissa D. "Marketing Gullah: Identity, Cultural Politics, and Tourism." Masters thesis, Knoxville, TN: University of Tennessee, 2000. Print.

Harris, Joel Chandler. Nights With Uncle Remus: Myths and Legends of the Old Plantation. Boston, MA: Houghton Mifflin, 1883. Print. 
Hefflin, Bena R. and Mary Alice Barksdale-Ladd. "African American Children's Literature That Helps Students Find Themselves: Selection Guidelines for Grades K-3." The Reading Teacher 54.8 (2001): 810-819. Print.

Herskovits, Melville J. Acculturation: The Study of Culture Contact. Glouchester, MA: Peter Smith, 1958. Print.

---. The Myth of the Negro Past. Boston, MA: Beacon Press, 1958. Print.

Herskovits, Melville J., and Frances S. Herskovits. The New World Negro: Selected Papers in Afroamerican Studies. Bloomington, IN: Indiana University Press, 1966. Print.

Herskovits, Melville J., R. Redfield, and Ralph Linton. "Memorandum for the Study of Acculturation." American Anthropologist 38 (1935): 149-152. Print.

Heyward, Duncan Clinch. Seed from Madagascar. Chapel Hill, NC: University of North Carolina Press, 1937. Print.

"Hilton Head Island History." http://www.hiltonheadislandsc.gov/. Town of Hilton Head Island Beaufort County, South Carolina. 2009. Web. 2 June 2012.

"Hilton Head Island Town, South Carolina." http://www.factfinder2.census.gov/. 2010 US Census Bureau Profile of General Population and Housing Characteristics, 2010, Web. 30 May 2012.

"Historical Census Browser." http://mapserver.lib.virginia.edu/collections/. University of Virginia, Geospatial and Statistical Data Center, 2004. Web. 21 April 2012.

Holloway, Joseph F. Africanisms in American Culture. Bloomington, IN: Indiana University Press, 1991. Print.

hooks, bell. Rock my soul: Black people and self-esteem. New York, NY: Washington Square Press, 2003. Print.

Hughes, Langston, and Arna Bontemps, ed. Book of Negro Folklore. New York, NY: Dodd and Meade, 1958. Print.

Hurston, Zora Neale. Mules and Men. New York, NY: Negro Universities Press, 1969. Print.

"Island History." http://www.daufuskieislandhistoricalfoundation.org. The Daufuskie Island Historical Foundation . unknown year. Web. 2 June 2012. 
Jackson, Bruce. American Folklore Society, Judith McCulloh, and Marta Weigle. Folklore/ Folklife. Ed. Bruce Jackson and American Folklore Society. Bloomington, IN: Indiana University, 1984. Print.

Jaquith, Priscilla. "Folktales Decisions.” Ed. Gary D. Schmidt and Donald R. Hettinga. Sitting at the Feet of the Past: Retelling the North American Folktales for Children. Westport, CT: Greenwood Press, 1992. 77-79. Print.

Jewell, K. Sue. Survival of the African American Family: The Institutional Impact of U.S. Social Policy. Westport, CT: Praeger Publishers, 2003. Print.

"Johns Island CCD, Charlestown, South Carolina." http://www.factfinder2.census.gov/. 2010 US Census Bureau Profile of General Population and Housing Characteristics, 2010, Web. 1 June 2012.

"Johns Island, South Carolina." http://www.sciway.net/city/johnsisland.html. South Carolina's Information Highway. 2012. Web. 2 June 2012.

Jones, Charles C. Gullah Folktales from the Georgia Coast. Athens, GA: University of Georgia Press, 2000. Print.

---. Negro Myths from the Georgia Coast, Told in the Vernacular. Boston, MA: Houghton, Mifflin, 1888. Print.

Jones-Jackson, Patricia. When Roots Die/ Endangered Traditions on the Sea Islands. Athens, GA: University of Georgia Press, 1987. Print.

Joyner, Charles. Down by the Riverside: A South Carolina Slave Community. Urbana, IL: University of Illinois Press, 1984. Print.

---. Shared Traditions: Southern History and Folk Culture. Urbana, IL: University of Illinois Press, 1999. Print.

Kemble, Frances A. Journal of a Residence on a Georgian Plantation in 18381839. Athens, GA: University of Georgia Press, 1984. Print.

Keenan, Hugh T. "Joel Chandler Harris and the Legitimacy of the Reteller of Folktales." Ed. Gary D. Schmidt and Donald R. Hettinga. Sitting at the Feet of the Past: Retelling the North American Folktales for Children. Westport, CT: Greenwood Press, 1992. 81-91. Print.

Kennedy, V. Lynn. Born Southern: Childbirth, Motherhood, and Social Networks in the Old South. Baltimore, MD: The John Hopkins University Press, 2010. Print.

King, Wilma. Stolen Childhood: Slave Youth in Nineteenth-Century America. 
Bloomington, IN: Indiana University Press, 1995. Print.

Lester, Julius. On Writing for Children \& Other People. New York, NY: Dial Books, 2004. Print.

Lewis-Wade, Margaret. Lorenzo Dow Turner: Father of Gullah Studies. Columbia, SC: University of South Carolina Press, 2007. Print.

Levine, Lawrence W. Black Culture and Black Consciousness: Afro-American Folk Thought from Slavery to Freedom. New York, NY: Oxford University Press, 1977. Print.

Littlefield, Daniel C. Rice and Slaves: Ethnicity and the Slave Trade in Colonial South Carolina. Baton Rouge, LA: Louisiana State University Press, 1981. Print.

Long, Richard A. "Gullah Culture Special Resource Study Statement of National Historical and Cultural Significance." Low Country Gullah Culture Special Resource Study. Atlanta, GA: NPS Southeast Regional Office, 2005. 101-103. Print.

Lucas, Eliza. The Letterbook of Eliza Lucas Pinckney, 1739-1762. Charlestown, SC: The South Carolina Historical Society, 1972. Print.

Manna, Anthony L. "Br'er Rabbit Redux." Ed. Gary D. Schmidt and Donald R. Hettinga. Sitting at the Feet of the Past: Retelling the North American Folktales for Children. Westport, CT: Greenwood Press, 1992. 93-108. Print.

Martin, Chlotilde R. Northern Money, Southern Land: The Lowcountry Plantation Sketches of Chlotilde R. Martin. Ed. Robert B. Cuthbert and Stephen G. Hoffius. Columbia, SC: University of South Carolina Press, 2009. Print.

May, Jill P. "Theory and Textual Interpretation: Children's Literature and Literary Criticism," The Journal of the Midwest Modern Language Association 30.5 (1997): 81-96. Print.

McAdoo, Harriette Pipes, ed. Black Children: Social, Educational, and Parental Environments. Second Ed. Thousand Oaks, CA: Sage Publications Inc., 2002. Print.

---. Black Families. Fourth ed. Thousand Oaks, CA: Sage Publications, Inc., 2007. Print.

McAdoo, Harriette Pipes. "The Village Talks: Racial Socialization of Our Children.” Ed. Harriette Pipes McAdoo, Black Children: Social, 
Educational, and Parental Environments. Thousand Oaks, CA: Sage Publications Inc., 2002. 47-55. Print.

Montrose, Louis. "Renaissance Literary Studies and the Subject of History," English Literary Renaissance 16 (1986): 6. Print.

Murray, Carolyn Bennett and Jelani Mandara. "Racial Identity Development in African American Children: Cognitive and Experiential Antecedents." Ed. Harriette Pipes McAdoo, Black Children: Social, Educational, and Parental Environments. Thousand Oaks, CA: Sage Publications Inc., 2002. 73-96. Print.

Nathans, Sydney. "Fortress Without Walls: A Black Community After Slavery. In Holding on to the Land and the Lord." Ed. Robert Hall and Carol B. Stack. Southern Anthropological Society Proceedings, No. 15. Athens, GA: University of Georgia Press, 1982. 55-68. Print.

National Park Service. Low Country Gullah Culture Special Resource Study. Atlanta, GA: NPS Southeast Regional Office, 2005. Print.

Newby, Idus A. Black Carolinians: A History of Blacks in South Carolina From 1895 to 1968. Columbia, South Carolina: University of South Carolina Press, 1973. Print.

Nichols, Patricia C. "Storytelling in Carolina: Continuities and Contrasts." Anthropology \& Education Quarterly 20.3 (1989): 232-245. Print.

Nobles, Wade W. "African American Family Life: An Instrument of Culture." Black Families. Ed. Harriette Pipes McAdoo. Fourth ed. Thousand Oaks, CA: Sage Publications, Inc., 2007. 69-78. Print.

Ochiai, Akiko. "The Port Royal Experiment Revisited: Northern Visions of Reconstruction and the Land Question," The New England Quarterly 74.1 (2001): 94-117. Print.

Opala, Joseph. The Gullah: Rice, Slavery, and the Sierra Leone-American Connection. Freetown, Sierra Leone: USIS, 1987. Electronic Source.

Pilgrim, David. "Who Was Jim Crow?" Jim Crow Museum of Racist Memorabilia, Ferris State University, Sept. 2000. Web. 18 April 2012.

Pipes, William Harrison. “Old Time Religion: Benches Can't Say 'Amen.” Ed. Harriette Pipes McAdoo, Black Families. Fourth ed. Thousand Oaks, CA: Sage Publications, Inc., 2007. 101-124. Print. 
Pollitzer, William S. The Gullah People and Their African Heritage. Athens, Georgia: University of Georgia Press, 1999. Print.

Powers, Bernard E. Jr. "A Founding Father and Gullah Culture: The National Park Service traces the dual plantation heritage at the Charles Pinckney National Historic Site near Charleston, South Carolina." The Magazine of the National Parks and Conservation Association National Parks Conservative Association 72.11-12 (1998): 26-29. Web.

Puckett, Newbell N. Folk Beliefs of the Southern Negro. Chapel Hill, NC: University of North Carolina, 1926. Print.

Reddick, Lawrence D. Crusader without Violence. New York, NY: Harper \& Row, Publishers, 1959. Print.

Roberts, John W. "African American Diversity and the Study of Folklore." Western Folklore 52.2/4, (1993): 157-171. Print.

---. From Trickster to Badman: The Black Folk Hero in Slavery and Freedom. Philadelphia, PA: University of Pennsylvania Press, 1989. Print.

Roney, Craig. "Telling Stories: A Key to Reading and Writing." Ed. Gloria T. Blatt. Once Upon a Folktale: Capturing the Folklore Process With Children. New York, NY: Teachers College Press, 1993. 9-25. Print.

Rose, Willie Lee. Rehearsal for Reconstruction: the Port Royal Experiment. Indianapolis, IN: Bobbs-Merrill, 1964. Print.

Rourke, Constance. American Humor: A Study of the National Character. New York, NY: Harcourt, Brace, and Company, 1931. Print.

Sanfield, Steve. "Across Cultures: Stories That Say L'Chaim." Ed. Gary D. Schmidt and Donald R. Hettinga. Sitting at the Feet of the Past: Retelling the North American Folktales for Children. Westport, CT: Greenwood Press, 1992. 69-76. Print.

Schmidt, Gary D. and Donald R. Hettinga, Ed. Gary D. Schmidt and Donald R. Hettinga. Sitting at the Feet of the Past: Retelling the North American Folktales for Children. Westport, CT: Greenwood Press, 1992. Print.

Sengova, Joko. "My Mother Dem Nyus to Plan' Reis: Reflections on Gullah/Geechee Creole Communication, Connections, and the Construction of Cultural Identity." Ed. Kevin A Yelvington. Afro-Atlantic Dialogues: Anthropology in the Diaspora. Santa Fe, New Mexico: School of American Research Press, 2006. 211-248. Print. 
Sims, Martha and Martine Stephens. Living Folklore: An Introduction to the Study of People and Their Traditions. Logan, UT: Utah State University Press, 2005. Print.

Smith, Henry A.M. "The Baronies of South Carolina." Ed. Mabel Louise Webber, The South Carolina historical and genealogical magazine 16.4, South Carolina Historical Society (1914): 149-165. Print.

Smith, John D. "The Unveiling of Slave Folk Culture, 1865-1920.” Journal of Folklore Research 21.1 (1984): 47- 62. Print.

Smith, Mark, ed. Stono: Documenting and Interpreting a Southern Slave Revolt. Columbia, SC: University of South Carolina Press, 2005. Print.

South Carolina Community Profiles: Census Tracts. Sccommunityprofiles.org. South Carolina Budget and Control Board's Office of Research and Statistics, 2011.Web. 21 April 2012.

"St. Helena Island CCD, Beaufort County, South Carolina." http://www.factfinder2.census.gov/. 2010 US Census Bureau Profile of General Population and Housing Characteristics, 2010, Web. 30 May 2012.

"Sullivan's Island Historical and Architectural Inventory Survey Report 1987." http://www.sullivansisland-sc.com/. Town of Sullivan's Island Official Website. 2007-2008. Web. 2 June 2012.

"Sullivan's Island town, South Carolina." http://www.factfinder2.census.gov/. 2010 US Census Bureau Profile of General Population and Housing Characteristics, 2010, Web. 2 June 2012.

"The Gullah of Daufuskie Island, SC: 300 Years of African American Life on Daufuskie Island, SC." http://daufuskieislandhistoricalfoundation.org/Gullah-of-Daufuskie.html. The Daufuskie Island Historical Foundation, 2010. Web. 7 June 2012.

Turner, Lorenzo Dow. Africanisms in the Gullah Dialect. Chicago, IL: University of Chicago Press, 1949. Print.

Twining, Mary A. and Keith E. Baird. "Introduction to Sea Island Folklife." Journal of Black Studies 10.4. (1980): 387-416. Print.

---. "Sea Island Culture: Matrix of the African American Family." Ed. Mary A. Twining and Keith E. Baird Sea Island Roots: African Presence in the Carolinas and Georgia. Trenton, NJ: Africa World Press, 1991. Print. 
--.. Sea Island Roots: African Presence in the Carolinas and Georgia. Trenton, NJ: Africa World Press, 1991. Print.

Wallace, David Duncan. The History of South Carolina. New York, NY: The American Historical Society, 1935. Print.

Wilkerson, Isabel. The Warmth of Other Suns: The Epic Story of America's Great Migration. New York, NY: Random House, 2010. Print.

Wood, Peter. Black Majority: Negroes in Colonial South Carolina from 1670 through the Stono Rebellion. New York, NY: W.W. Norton and Company, 1974. Print.

"Info Page." http://www.worldatlas.com. Graphic Maps, Woolwine-Moen Group. 2012. Web. 14 July 2012.

Wright, Marguerite A. I'm Chocolate You're Vanilla: Raising Healthy Black and Biracial Children in a Race-Conscious World. San Francisco, CA: JosseyBass Publishers, 1998. Print.

Young, Terrell A., Joseph Bruchac, Nancy Livingston, and Catherine Kurkjian. "Children's Books: Folk Literature: 'Preserving the Storytellers' Magic." The Reading Teacher, 57.8 (2004): 782-792. Print.

Young, Terrell A., and Phyllis M. Ferguson, "From Anansi to Zomo: Trickster Tales in the Classroom." The Reading Teacher 48.6 (1995): 490-503. Print. 
Table 1

2000 U.S. Census Tracts of South Carolina

\begin{tabular}{|c|c|c|c|c|c|c|}
\hline $\begin{array}{c}\text { Sea Islands } \\
\text { in S.C. }\end{array}$ & $\begin{array}{c}\text { Land } \\
\text { Tracts }\end{array}$ & $\begin{array}{c}\text { Total } \\
\text { Population }\end{array}$ & $\begin{array}{c}\text { White } \\
\text { Population }\end{array}$ & $\begin{array}{c}\text { Percentage } \\
\%\end{array}$ & $\begin{array}{c}\text { African } \\
\text { American } \\
\text { Population }\end{array}$ & $\begin{array}{c}\text { Percentage } \\
\text { \% }\end{array}$ \\
\hline $\begin{array}{c}\text { Daufuskie } \\
\text { Island }\end{array}$ & Tract 21 & 14,246 & 11,660 & 81.8 & 1,987 & 13.9 \\
\hline $\begin{array}{c}\text { St. Helena } \\
\text { Island }\end{array}$ & Tract 12 & 1,079 & 1,071 & 99.3 & 3 & 0.3 \\
\hline $\begin{array}{c}\text { Hilton } \\
\text { Head Island }\end{array}$ & Tract 104 & 2,836 & 1,958 & 69 & 666 & 23.5 \\
\hline $\begin{array}{c}\text { Hilton } \\
\text { Head Island }\end{array}$ & Tract 107 & 4,184 & 4,062 & 97.1 & 68 & 1.6 \\
\hline $\begin{array}{c}\text { Sullivan's } \\
\text { Island }\end{array}$ & Tract 48 & 1,911 & 1,887 & 98.7 & 12 & 0.6 \\
\hline $\begin{array}{c}\text { Johns } \\
\text { Island }\end{array}$ & Tract 50 & 5,091 & 1,171 & 34.8 & 3,259 & 64.0 \\
\hline \hline
\end{tabular}


Table 2

2010 U.S. Census of South Carolina

\begin{tabular}{|c|c|c|c|c|c|}
\hline $\begin{array}{c}\text { Counties in } \\
\text { S.C. }\end{array}$ & $\begin{array}{c}\text { Total } \\
\text { Population }\end{array}$ & $\begin{array}{c}\text { White } \\
\text { Population }\end{array}$ & $\begin{array}{c}\text { Percentage } \\
\%\end{array}$ & $\begin{array}{c}\text { African } \\
\text { American } \\
\text { Population }\end{array}$ & $\begin{array}{c}\text { Percentage } \\
\%\end{array}$ \\
\hline $\begin{array}{c}\text { Daufuskie } \\
\text { Island }\end{array}$ & 250 & $\begin{array}{c}230 \\
\text { (estimated) }\end{array}$ & N/A & $\begin{array}{c}>20 \\
\text { (estimated) }\end{array}$ & N/A \\
\hline $\begin{array}{c}\text { St. Helena } \\
\text { Island }\end{array}$ & 22,051 & 13,446 & 61 & 7,486 & 33.9 \\
\hline $\begin{array}{c}\text { Hilton Head } \\
\text { Island }\end{array}$ & 37,793 & 31,419 & 83.1 & 2,776 & 7.3 \\
\hline $\begin{array}{c}\text { Sullivan's } \\
\text { Island }\end{array}$ & 1,791 & 1,762 & 98.4 & 14 & 0.8 \\
\hline $\begin{array}{c}\text { Johns Island } \\
\text { Island }\end{array}$ & 15,181 & 9,568 & 63 & 4,257 & 28 \\
\hline
\end{tabular}

Source: U.S. Census Bureau, Census 2010. 
Map

$\underline{\text { South Carolina Sea Islands }}$

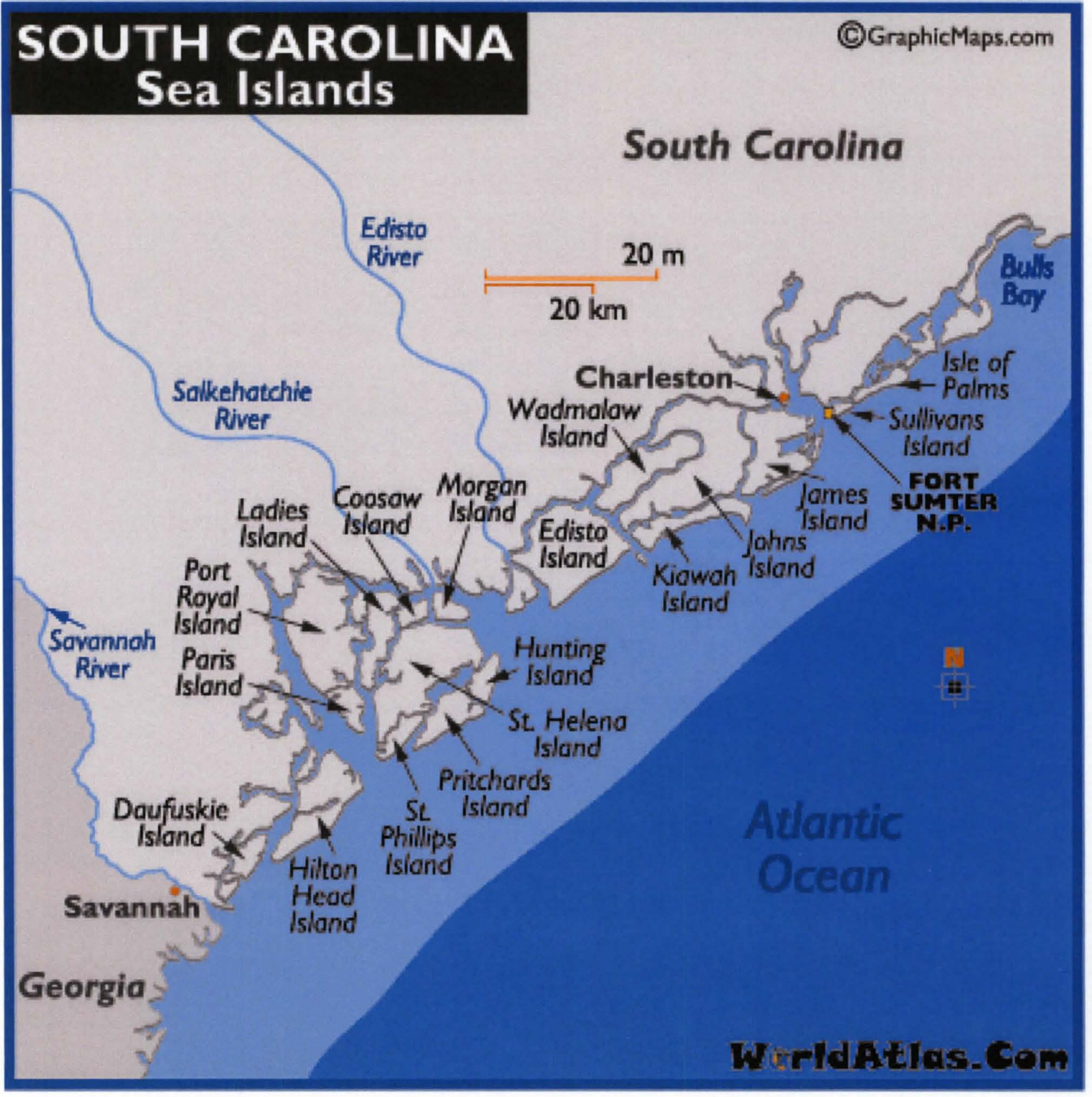




\title{
CURRICULUM VITAE
}

\author{
NAME: Tytianna Nikia Maria Wells Smith \\ ADDRESS: 3257 Taylor Blvd \\ Louisville, Kentucky 40215 \\ EMAIL: $\quad$ Tnwell01@yahoo.com \\ DOB: Detroit, Michigan- February 24, 1987

\section{EDUCATION}

M.A. Pan-African Studies (January 2011- August 2012)

University of Louisville, Louisville, KY

Cumulative Grade Point Average: 3.841

Concentrations: African American History, African American Cultural

Traditions, Black Folktales, African American Literature, Black Family

\section{Study Abroad}

Pan-African Studies Trinidad \& Tobago: University of West Indies (July 2007)

African American Theatre Program: Beijing, Hong Kong, Xiamen, China (Dec 2007)

Muhammad Ali Institute Scholars Program: Morocco and Senegal, Africa, Universite

Gaston Berge de Saint Louis (May 2008)

B.A. $\quad$ English (August 2005-December 2009)

Concentration: African American Literature

University of Louisville, Louisville, KY

Cumulative Grade Point Average: 2.63

B.A. Pan-African Studies (August 2005-December 2009)

University of Louisville, Louisville, KY

Cumulative Grade Point Average: 3.725

Cum Laude

Cumulative Graduating GPA: 3.03 


\section{ACADEMIC AWARDS}

\section{Graduate Dean's Citation}

School of Interdisciplinary and Graduate Studies

University of Louisville, 2012

Graduate Teaching Assistantship (GTA) Academy, Participant

University of Louisville, Fall 2011-Spring 2012

Anne Braden Institute for Social Justice Research, Graduate Assistantship (GA)

Department of Pan-African Studies,

University of Louisville, Fall 2011-Spring 2012

U of L Creative Writing Scholarship

Department of English

University of Louisville, 2011-2012

Pan-African Graduate Student Association (PGSA), Vice-President

Department of Pan-African Studies

University of Louisville, Fall 2011

University of Louisville, Dean's List

University of Louisville, Fall 2011

University of Louisville, Dean's Scholar

University of Louisville, Summer 2011

University of Louisville, Dean's List

University of Louisville, Spring 2011

University of Louisville, Dean's List

University of Louisville, Spring 2009

Outstanding Undergraduate Senior: Nancy Pollock Memorial Award Department of Pan-African Studies

University of Louisville, 2009

University of Louisville, Fola Iyun Scholarship

Department of Pan-African Studies

University of Louisville, 2008-2009

U of L Creative Writing Scholarship

Department of English

University of Louisville, 2008-2009

Muhammad Ali Institute for Peace and Justice Scholarship Program

University of Louisville, 2007-2009 


\section{KEES Scholarship}

University of Louisville, 2005-2009

Woodford R. Porter Full Tuition Scholarship

University of Louisville, 2005-2009

Most Outstanding C.O.N.E.C.T. Peer Mentor Program Award

University of Louisville, 2007-2008

Distance Education Scholarship

Department of Pan-African Studies

University of Louisville, 2007-2008

U of L Creative Writing Scholarship

Department of English

University of Louisville, 2007-2008

University of Louisville, Dean's Scholar

University of Louisville, Spring 2008

University of Louisville, Dean's List

University of Louisville, Fall 2008

U of L Creative Writing Scholarship

Department of English

University of Louisville, 2006-2007

Outside Scholarship

University of Louisville, 2005-2006

\section{PUBLICATIONS}

\section{The Black Hawk Publication}

All monthly volumes and issues were comprised of various articles, many of which were written by the founder between April 2006-August 2009. Samples of the publication are available in print only.

\section{Courier-Journal Teen Hot Spot Blog}

Protecting Our Children

October 21, 2008

A Reader's Misconception

October 20, 2008

Proclaiming Power and Dignity

October 15, 2008 
A Simple Game, A Complex History

October 15, 2008

What a Woman Must Do

October 15, 2008

A Cultural Exchange: Reflecting on China

February 5, 2008

AATP Performs Three Plays in China

Daily Blog from China to the U.S.

December 2- December 20, 2007

Walking to Remember

October 15, 2007

Feeding Your Spirit

October 10, 2007

U of L Take's Back the Night

September 27, 2007

A Sac of Problems

September 25, 2007

Impoverished Minds Lead Impoverished Lives

September 22, 2007

Treason to Whiteness is Loyalty to Humanity

September 21, 2007

\section{The Louisville Cardinal Newspaper}

Student Athletes Take Advantage of Tutoring

October 23, 2007

Despite Strides, Some Students See Segregation on Campus

September 25, 2007

September $11^{\text {th }}$ Marks Spiritual Change for Professor

Professor Profile: Dr. Denise Martin

September 11, 2007

Couples Spend Semester at Sea

September 4, 2007

Students Face Dorm Dilemmas

August 21, 2007 
Annual Event Celebrates, Inspires Change for Women

August 21, 2007

\section{Louisville Eccentric Observer (LEO) Weekly}

Grotesque Burlesque Valentine

Feb 10, 2006

Candy Licker: An Urban Erotic Tale

Book Review

Feb 15, 2006

Expressions of You Provides an Open Stage and a Refuge

March 22, 2006

Nibbles Dinning News Bits Section:

Uncorked Wine Tasting: Glassworks

Wine Advertisement

March 8, 2006

Eat All Day: Gumbo A Go-Go

Restaurant Advertisement

March 29, 2006

Arts \& Entertainment Section:

A PEACE of Musical Harmony

Music Advertisement

January 11, 2006

Zora Neale Hurston Celebration

Black History Advertisement

January 25, 2006

'Crossing Over' Freedom Walk

Tribute Advertisement

February 22, 2006

A Tribute to Paul Laurence Dunbar

Tribute Advertisement

March 19, 2006

Trio Joubran

Music Review

April 5, 2006 
Wise Guys Fabrication Grand Opening

Restaurant Review

April 26, 2006

"Colored Troops In the Civil War"

Lecture Advertisement

February 22, 2006

\section{The Louisville Patriot}

$U$ of L Assists Displaced Students from Gulf

September 2005

\section{MEDIA INTERVIEW}

University of Louisville Cardinal Cam (December 2007). The Journey of a World Explorer \{Online\}. Available at http://louisville.edu/cardinalcam/

\section{PROFESSIONAL ACADEMIC EXPERIENCE}

Administrative

Associate Educator, Muhammad Ali Center

Louisville, KY (2012-present)

Substitute Teacher, Jefferson County Public Schools (JCPS)

Louisville, KY (2010-present)

Graduate Assistant, Anne Braden Institute for Social Justice Research

Louisville, KY (2011-2012)

Math Tutor, St. George's Community Center

Louisville, KY (2010-2011)

Youth Counselor, Maryhurst, Inc. (Psychiatric Residential Treatment Facility)

Louisville, KY (2010)

After- School Program Teacher, Americana Community Center

Louisville, KY (2010)

Co-founder of S.H.E. (Solidifying Her Evolution) Choreopoetry Group

Louisville, KY (2007-2010)

Print Journalist, Courier-Journal Teen Hot Spot Blog

Louisville, KY (2007-2009) 
Academic Peer Mentor/ Community Service Chair, C.O.N.E.C.T

Peer Mentoring Program

University of Louisville (2007-2009)

Founder/ Editor-In-Chief/ Layout Designer, The Black Hawk Publication

University of Louisville (2006-2009)

Broadcast \& Print Journalist, University of Louisville Cardinal Cam

University of Louisville (2007-2008)

Print Journalist, The Louisville Cardinal Newspaper

University of Louisville (2006-2007)

\section{Teaching}

Long-Term JCPS Substitute Teacher

08/30/2010- 11/23/2010 Fern Creek High School, ECE/LBD English Teacher, Created/ Organized Curriculum Approved by JCPS, PD Trained, Louisville, KY.

04/28/2010- 05/21/2010 Valley High School, ECE/LBD Math, Science, and Social Studies Teacher. Louisville, KY.

Short-Term JCPS Substitute Teacher

K-12 School

Brown School, Louisville, KY

Elementary School

Slaughter Elementary School, Louisville, KY

McFerran Preparatory Academy, Louisville, KY

Kennedy Montessori Elementary School, Louisville, KY

Kenwood Elementary School, Louisville, KY

Breckinridge- Roosevelt Elementary School, Louisville, KY

King Elementary School, Louisville, KY

Jacob Elementary School, Louisville, KY

Kerrick Elementary, Louisville, KY

\section{Middle School}

Moore Traditional Middle School, Louisville, KY

Conway Middle School, Louisville, KY

Noe Middle School, Louisville, KY

Lassiter Middle School, Louisville, KY

Westport Middle School, Louisville, KY

Johnson Traditional Middle Elementary, Louisville, KY

Stuart Middle School, Louisville, KY

Olmstead North Middle School, Louisville, KY 
Myers Middle School, Louisville, KY

Thomas Jefferson Middle School, Louisville, KY

\section{High School}

Fern Creek High School, Louisville, KY

Valley High School, Louisville, KY

Seneca High School, Louisville, KY

Iroquois High School, Louisville, KY

Western High School, Louisville, KY

Fairdale High School, Louisville, KY

Wagner High School, Louisville, KY

Westport TAPP School (Teenage Parent Program), Louisville, KY

Eastern High School, Louisville, KY

Shawnee High School, Louisville, KY

Atherton High School, Louisville, KY

Liberty High School, Louisville, KY

Pleasure Ridge Park High School, Louisville, KY

Central High School, Louisville, KY

\section{Internships}

\section{Communications Internship}

March of Dimes Louisville Chapter

Louisville, KY (2009)

Department of Communications Internship

Children's Defense Fund (CDF) National Headquarters

Washington, D.C. (2008)

Political Internship

Legislative Research Commission (LRC) State Capitol

Frankfort, KY (2007)

Freedoms Schools Servant Leader Intern

Children's Defense Fund (CDF)

Louisville, KY (2007)

\section{Journalism Internship}

Louisville Eccentric Observer (LEO) Weekly

Louisville, KY (2006)

\section{RESEARCH}

University of Louisville

2012 "An Exploration of African Folktales among the Gullah Community of the South Carolina Sea Islands: History, Culture, and Identity." PAS 604: Thesis, Dr. Yvonne Jones. 
"Deconstructing Juvenile Delinquency in the African American Community." PAS 408: Research Methods-WR, Dr. Jennifer Jewell.

2009 "Black Parenting Styles Impact Racial Socialization." PAS 352:

The Black Child, Dr. Danielle Brown.

"People's of the Sea (Rojo): Trinidadian Folklore/ Mythology."

PAS 586: Field Research- Trinidad \& Tobago, Dr. Theresa Rajack- Talley.

\section{INVITED PRESENTATIONS \& CONFERENCES}

2012

2012

2012

2012

2011

2011

2011

2011

2011

Advocacy Track Participant, "Campus Progress National Conference," Washington, D.C.

$39^{\text {th }}$ Annual Joseph H. McMillan Black Family Conference, Presenter of "An Exploration of African Folktales among the Gullah Community of the South Carolina Sea Islands: History, Culture, and Identity." Louisville, KY.

Anne Braden Institute for Social Justice Research, created a JCPS Social Studies Interactive Teaching Curriculum for local teachers focusing on the Civil Rights Movement in Kentucky including the history of the late Anne Braden. Graduate Assistant Project. University of Louisville, Louisville, KY.

Guest Speaker, "Motivational Speaker," Empire Beauty School. Louisville, KY.

Anne Braden Institute for Social Justice Research, created a Book Discussion Group Kit/ Reader's Guide for Dr. Michelle Alexander's The New Jim Crow: Mass Incarceration in the Age of Colorblindness. Graduate Assistant Project. University of Louisville, Louisville, KY.

Bonner Leaders Present How Can We Best Serve Workshop. Anne Braden Institute for Social Justice Research, Joint-Presenter of Candid Conversation about Racial Inequality. Session Two. University of Louisville, Louisville $\mathrm{KY}$.

Anne Braden Institute for Social Justice Research, $5^{\text {th }}$ Annual Lecture, JointIntroduction of speaker, Dr. Michelle Alexander, author of The New Jim Crow: Mass Incarceration in the Age of Colorblindness. University of Louisville, Louisville KY.

International Day of Peace, Joint- Presenter of Anne Braden Institute for Social Justice Research, Graduate Assistant Project. University of Louisville, Louisville, KY.

Delta Academy Program, Presenter of "My Black is Beautiful." Delta Sigma Theta Sorority, Incorporated. Louisville Alumnae Chapter, Louisville, KY. 
Delta Jabberwok, Presenter of "Confessions of a College Student."

Delta Sigma Theta Sorority, Incorporated. Louisville Alumnae Chapter, Louisville, KY.

S.H.E! Workshop, “Women's Empowerment," Maryhurst, Inc., Louisville, KY.

S.H.E! Workshop, “Women's Empowerment," Delta Academy Program: A Celebration of Women, Delta Sigma Theta Sorority, Incorporated. Louisville Alumnae Chapter, Louisville, KY.

S.H.E.! Workshop, "IDENTITY," Shelby Park, Women In Transition (WIT), The People's Fest: Building Unsettling Movement: A National Conference to End Poverty, Louisville, KY.

S.H.E! Workshop, "Women's Empowerment," Saturday Academy-Sister Summit \#4, Park Duvall Community Center, Louisville, KY.

S.H.E! Workshop, "IDENTITY," River Bend Winery, Louisville, KY.

S.H.E! Workshop, "Black History," Collegiate 100 Black Women's Appreciation Dinner, University of Louisville, Louisville, KY.

S.H.E! Workshop, "IDENTITY," Collegiate 100/SAAB RSO Black Women's Appreciation Dinner, University of Louisville, Louisville, KY.

S.H.E! Workshop, "LGBT Empowerment," Lesbian Gay Bisexual Transgender (LGBT) Services Program, University of Louisville, Louisville, KY.

Spoken Word Soloist, "Once Upon A Time," Zeta Phi Beta Sorority, Incorporated. Black Men's Appreciation Dinner, University of Louisville, Louisville, KY.

S.H.E! Workshop, "Black History," Americana Community Center, Dr. Martin Luther King, Jr. Celebration, Louisville, KY.

S.H.E! Workshop, "LGBT Empowerment," Rudyard Kipling, Louisville, KY.

Participant, "The Joshua \& Deborah Generation," Samuel DeWitt Proctor Institute for Child Advocacy Ministry, Alex Haley Farm, Clinton, TN.

Participant, "Young Adult Leadership Training (YALT) Program," Children's Defense Fund, Alex Haley Farm, Clinton, TN.

Journalism Track Participant, "Campus Progress Southern Regional Conference," Morehouse College, Atlanta, GA. 
Tsakopoulous Library Galleria, Sacramento, CA.

2008

Guest Speaker, “Motivational Speaker," Paul Mitchell The SchoolLouisville. Louisville, KY.

2008

Journalism Tract Participant, "Campus Progress National Conference," Washington, D.C.

2008

2008

Participant, "Children's Defense Fund Freedom Schools National Day of Social Action," Washington, D.C.

S.H.E! Workshop, “Women Empowerment," Kentucky Social Forum Spoken-Word Showcase, Berea College, Berea, KY.

Panelist, "Building Sisterhood in the Black Community," Saturday AcademySister Summit \#3, Louisville, KY.

2008

S.H.E! Workshop, "IDENTITY," Association of Black Students (ABS) Talent Showcase, University of Louisville, Louisville, KY.

2008

S.H.E! Workshop, “IDENTITY,” S.H.E! Expressions of You Coffee House, Louisville, KY.

2008

Tytianna N.M. Wells Fundraiser, "A Fundraiser in the Arts for International Peace \& Justice," Blu Mountain Coffee House, Louisville, KY.

S.H.E! Workshop, “IDENTITY,” Blu Mountain Café, Louisville, KY.

2007

YMCA Black Achievers Program, Presenter of "The Black Hawk

Publication." YMCA Black Achievers Program, University of Louisville, Louisville, KY.

S.H.E! Workshop, "Celebrating Black History," University of Louisville Playhouse, Louisville, KY.

S.H.E! Workshop, “Black History,” Actor's Theatre, Louisville, KY.

African American Theatre Program (AATP) Performance/ Lecture, Mufaro's Beautiful Daughters, Beijing University, Beijing, China.

African American Theatre Program (AATP) Performance/ Lecture, Mufaro's Beautiful Daughters, Xiamen University, Xiamen, China.

African American Theatre Program (AATP) Lecture, African American Music, Xiamen University, Xiamen, China.

2007

Participant, "Ella Baker Child Policy National Training Institute," Children's Defense Fund Freedom Schools, University of Tennessee, Knoxville, TN. 
COMMUNITY SERVICE

2009- present Member. Delta Sigma Theta Sorority, Incorporated.

2008-2010 Volunteer. Big Brothers/Big Sisters of Kentucky. Louisville, KY.

2009 Childcare Specialist. Americana Community Center. Louisville KY. 